\title{
Threshold Effects of Air Pollution and Climate Change on Understory Plant Communities at Forested Sites in the Eastern United States
}

\author{
T.C. McDonnell ${ }^{1 *}$ \\ G.J. Reinds ${ }^{2}$ \\ G.W.W. Wamelink ${ }^{2}$ \\ P.W. Goedhart ${ }^{3}$ \\ M. Posch ${ }^{4}$ \\ T.J. Sullivan ${ }^{1}$ \\ C.M. Clark 5
}

March 4, 2020

*Corresponding author; todd.mcdonnell@esenvironmental.com

${ }^{1}$ E\&S Environmental Chemistry, Inc., PO Box 609, Corvallis, OR 97339

${ }^{2}$ Wageningen University and Research, Environmental Research (Alterra), P.O. Box 47, 6700 AA, Wageningen, The Netherlands

${ }^{3}$ Wageningen University and Research, Biometris, P.O. Box 16, 6700 AA Wageningen, The Netherlands

${ }^{4}$ International Institute for Applied Systems Analysis (IIASA), A-2361 Laxenburg, Austria

${ }^{5}$ US EPA, Office of Research and Development, National Center for Environmental Assessment, Washington DC, 20460, USA 
Abstract

Forest understory plant communities in the eastern United States are often diverse and are potentially sensitive to changes in climate and atmospheric inputs of nitrogen caused by air

25 pollution. In recent years, empirical and processed-based mathematical models have been

26 developed to investigate such changes in plant communities. In the study reported here, a robust

27 set of understory vegetation response functions (expressed as version 2 of the Probability of

28 Occurrence of Plant Species model for the United States [US-PROPS v2]) was developed based

29 on observations of forest understory and grassland plant species presence/absence and associated 30 abiotic characteristics derived from spatial datasets. Improvements to the US-PROPS model, 31 relative to version 1 , were mostly focused on inclusion of additional input data, development of 32 custom species-level input datasets, and implementation of methods to address uncertainty. We investigated the application of US-PROPS v2 to evaluate the potential impacts of atmospheric nitrogen $(\mathrm{N})$ and sulfur $(\mathrm{S})$ deposition, and climate change on forest ecosystems at three forested sites located in New Hampshire, Virginia, and Tennessee in the eastern United States. Specieslevel $\mathrm{N}$ and $\mathrm{S}$ critical loads (CLs) were determined under ambient deposition at all three modeled

37 sites. The lowest species-level CLs of $\mathrm{N}$ deposition at each site were between 2 and $11 \mathrm{~kg}$ N/ha/yr. Similarly, the lowest CLs of S deposition, based on the predicted soil $\mathrm{pH}$ response, were less than $2 \mathrm{~kg} \mathrm{~S} / \mathrm{ha} / \mathrm{yr}$ among the three sites. Critical load exceedance was found at all three model sites. The New Hampshire site included the largest percentage of species in exceedance.

41 Simulated warming air temperature typically resulted in lower maximum occurrence probability, which contributed to lower CLs of $\mathrm{N}$ and $\mathrm{S}$ deposition. The US-PROPS v2 model, together with the PROPS-CLF model to derive CL functions, can be used to develop site-specific CLs for 44 understory plants within broad regions of the United States. This study demonstrates that 
45 species-level CLs of $\mathrm{N}$ and $\mathrm{S}$ deposition are spatially variable according to the climate, light

46 availability, and soil characteristics at a given location. Although the species niche models

47 generally performed well in predicting occurrence probability, there remains uncertainty with

48 respect to the accuracy of reported CLs. As such, the specific CLs reported here should be

49 considered as preliminary estimates.

50

51 Keywords: Forest understory; biodiversity; nitrogen; climate change; critical load

53 Capsule: Critical loads of atmospheric nitrogen and sulfur deposition were determined for maintaining understory vegetation diversity. Critical load exceedance was found at all model 55 application sites.

INTRODUCTION

Changes in climate and atmospheric nitrogen $(\mathrm{N})$ and sulfur $(\mathrm{S})$ deposition in the eastern United States have resulted in pronounced changes in soil condition and habitat suitability for many plant species (U.S. EPA 2008, U.S. EPA 2009). Such changes in soil and habitat conditions are expected to continue in the future with further changing air temperature and

62 precipitation that may interact with effects of $\mathrm{N}$ deposition. At some locations, recovery from

63 earlier soil acidification, predominantly caused by S deposition, continues to play a major role as 64 a driver of vegetation response (Zarfos et al. 2019).

$66 \mathrm{~N}$ availability were among the most influential stressors affecting forest understory plant

67 biodiversity. Emissions of $\mathrm{N}$ have altered competitive interactions among plant species to favor 
69 plant species that are well-adapted to nutrient-poor conditions can be out-competed by other

70 species that are better adapted to high N supply (Hautier et al. 2009, de Vries et al. 2010, Payne

71 et al. 2013), with potential effects on forest plant diversity (Gilliam 2007, van Dobben and de

72 Vries 2017, Zarfos et al. 2019). The former are often native and relatively rare; the latter are

73 often non-native and invasive (Gilliam 2007).

74 Greenhouse gas emissions have increased temperature and altered precipitation patterns,

75 including in the eastern United States (IPCC 2013, U.S. Global Change Research Program

76 2017). Such fundamental changes may affect forest understory plant communities and should be

77 considered in conjunction with atmospheric $\mathrm{N}$ and $\mathrm{S}$ deposition. Even with substantial reductions

78 in $\mathrm{N}$ and S emissions and deposition throughout the eastern United States since the 1980s

79 (Sullivan et al. 2018), atmospheric concentrations and deposition of $\mathrm{N}$ are higher than

80 preindustrial conditions (Galloway et al. 2008, Sullivan 2017).

81 The ability of eastern forest vegetation communities to recover from relatively high past

$82 \mathrm{~N}$ inputs is unclear, as is the influence of climate change on such recovery (McDonnell et al.

83 2014, Phelan et al. 2016, Stevens 2016, McDonnell et al. 2018). Climate affects virtually all

84 aspects of $\mathrm{N}$ cycling, mainly through changes in soil microbial activity and tree uptake (Suddick

85 et al. 2013). Temperature and precipitation patterns have changed during recent decades and are

86 expected to change further in the coming decades (IPCC 2013). Increasing temperature and

87 precipitation may increase plant growth, making plant communities more sensitive to changes in

$88 \mathrm{~N}$ availability. However, increasing temperature and precipitation may also increase

89 decomposition of soil organic matter and $\mathrm{N}$ availability, making plant communities less

90 dependent on external sources of $\mathrm{N}$ such as atmospheric deposition (Clark et al. 2019). 
The majority of forest plant species biodiversity is found in the understory community

92 (Gilliam 2007). The herb layer tends to respond clearly and quickly to disturbance across broad

93 spatial scales and often partly reflects historical patterns of disturbance and successional stage

94 (Gilliam 2007). Varying levels of $\mathrm{N}$ input have been associated with decreases in species

95

96

97

98

99

100

101

102

103

104

105

106

107

108

109

110

111

112

113

richness in plot experiments (Clark et al. 2007, Clark and Tilman 2008, Bowman et al. 2012) and

regional studies across $\mathrm{N}$ deposition gradients (Stevens et al. 2010b, Simkin et al. 2016).

The total number of species present at a given site, termed species richness, is commonly

used as a metric to express biodiversity. Addition of $\mathrm{N}$ to vegetation communities can increase, decrease, or have no effect on richness, depending on many other stressors (Simkin et al. 2016).

Key processes include release of opportunistic species from N-limitation (Bobbink and Hicks 2014), competitive exclusion (Hautier et al. 2009), soil acidification (Stevens et al. 2010a), environmental filtering (Kraft et al. 2015), base cation depletion (Zarfos et al. 2019), and nutrient imbalances (Chen et al. 2013).

Critical loads (CLs) have been used extensively to inform environmental policy relating to emissions standards (U.S. EPA 2009). The CL is the deposition load (usually of N and/or S) below which harmful effects on ecosystems are not expected to occur according to present knowledge (Nilsson and Grennfelt 1988). CLs can be used to protect or restore either terrestrial or aquatic receptors (Sullivan 2012). Critical loads to protect biodiversity at individual sites or at regional scales can be used to evaluate the potential effects of emissions, which are important to land managers, especially those responsible for managing wilderness and national parks.

Models have been developed to estimate the response of forest understory plant communities to anthropogenic $\mathrm{N}$ and $\mathrm{S}$ input (de Vries et al. 2010). Coupled biogeochemicalvegetation models have been used to simulate the interactive effects caused by climate warming, 
114 increases or decreases in precipitation, and changes in $\mathrm{N}$ and $\mathrm{S}$ depostion inputs (Slootweg et al.

115 2015, Hettelingh et al. 2017). The PROPS model (Wamelink et al. 2011, Reinds et al. 2014) is a

116 statistically-based vegetation niche model. It uses existing species distributions to derive niche

117 information, which is then used to predict changes in plant abundance. The methodology was

118 initially developed for use in European natural and semi-natural vegetation systems. An initial

119 application of PROPS in the United States used PROPS linked with the Very Simple Dynamic

120 model with carbon (C) and nitrogen (N) cycling (VSD+; Bonten et al. 2016) to investigate

121 potential long-term impacts of acidic and nutrient-rich atmospheric deposition on hardwood

122 forest ecosystems in the context of changing climatic conditions (McDonnell et al. 2018).

123 Simulation results suggested that the site suitability for the continued presence of characteristic

124 understory plant species might decline during this century. However, low data availability for

125 defining niches (i.e., vegetation response functions modeled by PROPS) at the high and low

126 extremes of $\mathrm{N}$ deposition introduced uncertainty. Recently, vegetation observations in the United

127 States that had been aggregated by Simkin et al. (2016) were merged with PROPS to develop a

128 set of species niche models for ecosystems in the United States (McDonnell et al. 2018). In

129 addition to the VSD+ model, the PROPS model can be linked with the Critical Load Function

130 (CLF) methodology (Posch et al. 2015b, Posch 2017) to estimate CLs of atmospheric N and S

131 deposition to protect biodiversity under steady-state conditions. Uncertainties and other

132 limitations were identified in the application of the initial version of the United States' PROPS

133 models (McDonnell et al. 2018).

134 The goals of the research reported here were to improve on the first iteration of the US-

135 PROPS model described by McDonnell et al. (2018) to produce US-PROPS (v2) and present 
136 initial CL estimates generated by the US-PROPS-CLF model chain at three forested study sites

137 located in New Hampshire, Virginia, and Tennessee, with a focus on:

138

139

140

141

142

143

144

145

146

147

\section{METHODS}

149 Study Sites

150

151

152

153

154

155

156

157 Tennessee.
1) Including additional model input data.

2) Developing custom species-level input data sets based on only the vegetation surveys within and near to the known geographic extent of occurrence for a given species.

3) Including additional candidate predictor variables to describe light availability, soil conditions, and cumulative $\mathrm{N}$ deposition.

4) Expressing goodness-of-fit for each species model.

5) Providing a basis for quantifying uncertainty with respect to extrapolation beyond the range of abiotic conditions used for US-PROPS model development.

6) Determining CLs of $\mathrm{N}$ and $\mathrm{S}$ deposition for plant species.

The three sites modeled by McDonnell et al. (2018) were used here to test the application of selected species niche models derived from nationally available data. The three sites consisted of a 1) northern hardwood forest (Hubbard Brook; HB) located in the White Mountains National Forest at the HB Experimental Forest (HBEF) Long Term Ecological Research Station in New Hampshire; 2) mixed oak forest (Piney River; PR) in Shenandoah National Park (NP), Virginia; and 3) sugar maple-mixed oak forest (Cosby Creek; CC) in Great Smoky Mountains NP, 


\section{Species Model (US-PROPS v2) Development}

\section{Species Occurrence Data}

Vegetation survey data used in this study were taken mostly from the compilation of Simkin et al. (2016). The initial version of the US-PROPS database described by McDonnell et al. (2018) was based on only the portion of the Simkin et al. (2016) plots $(n=1,214)$ that were attributed with soil $\mathrm{C} / \mathrm{N}$ ratio. The full database of Simkin et al. (2016) was developed by compiling vegetation surveys with known geographic coordinates. The version used herein included 20,857 plots and consisted of 5,238 unique species, of which 1,555 occurred on at least 50 plots. The Simkin et al. (2016) database was augmented with vegetation survey data from Lawrence et al. (2015). Each vegetation survey consisted of a complete inventory of vascular plants found on a plot. Tree species were included only if they were found in the ground-layer strata. The five main datasets that comprised the vast majority $(93 \%)$ of the vegetation survey data used in this study were provided by: Ecological Society of America (VegBank; http://vegbank.org), Virginia Department of Conservation (https://www.dcr.virginia.gov), Minnesota Department of Natural Resources (https://www.dnr.state.mn.us), West Virginia Natural Heritage Program (Vanderhorst et al. 2012), and the USFS Forest Inventory and Analysis (FIA) database (Schulz and Dobelbower 2012). Additional details regarding vegetation input data can be found in Supplemental Material 1.

\section{Defining Species Range for Custom Species-Level Input Datasets}

Based on the full compiled set of vegetation survey plots $(n=20,806$; Figure 1), a unique set of input data was used for individual species model development. For each species, a subset of vegetation surveys were selected based on a general representation of the species 
geographic range according to available species occurrence maps. The USDA PLANTS statelevel species occurrence maps (https://plants.usda.gov) were used to define the geographic range for each species. These maps represent states in which the occurrence of a given species has been recorded based on botanical surveys, herbaria samples, and other empirical studies. Vegetation survey plots included within the geographic range for a given species were used, in conjunction with plot-level predictor variables, for model development.

\section{Predictor Variables}

Nine candidate predictor variables provided the basis for species model development. This set of predictors was based on an initial set of climate (mean annual temperature, [TANN]; total annual precipitation, [PPTANN]), and soil $\mathrm{pH}$ (SOILPH), as used in McDonnell et al. (2018), along with additional variables related to long-term average $\mathrm{N}$ deposition (NDEP30) light availability (incoming solar radiation, [SOLMJ]; canopy cover, [CC]), soil texture (soil percent clay, [SOILCLAY]), soil moisture (available water storage, [AWS]), and soil rooting depth (ROOTDEPTH; Supplemental Material 2). In addition to the precipitation amount, available water storage serves as a proxy for water availability (Webb et al. 1993) and contributes to species occurrence. This is done, in part, by representing the extent to which dry periods can be survived, and it is partly related to the soil type and the percentage of clay in the soil. Root depth partially determines a plant species ability to extract soil water, an important consideration given potential effects of future climate change on soil moisture availability (Bréda et al. 2006). Light availability, represented by canopy cover and solar radiation, is a key factor for plant growth and contributes to species occurrence (Austin and Van Niel 2011). Including canopy cover as a candidate predictor variable also accounts for differences in vegetation type 
204 (e.g., forest versus meadow). Although some spatial autocorrelation may be occurring, most of 205 the predictors were developed at a relatively fine scale $(30 \mathrm{~m})$, which helps to avoid pseudo206 replication among observations.

207

208

209

210

211

212

213

214

215

216

217

218

219

220

221

222

223

224

225

226

\section{Statistical Modeling Approach}

Logistic regression techniques were used to model the probability $(\pi)$ that a species occurs as a function of the nine predictor variables. Predictors NDEP30, PPTANN, SOILCLAY, ROOTDEPTH and AWS were log transformed, and all (transformed) predictors were normalized to have mean $=0$ and standard deviation $=1$. The logistic regression model employed was quadratic in each of the predictors:

$$
\operatorname{logit}(\pi)=\log \left(\frac{\pi}{1-\pi}\right)=\alpha+\sum_{i=1}^{9}\left(\beta_{i} x_{i}+\gamma_{i} x_{i}^{2}\right)
$$

where $x_{i}$ represents the (transformed/normalized) predictor variables and $\alpha, \beta_{i}$ and $\gamma_{i}$ are parameters which were estimated from the presence/absence data for the species within the empirical range defined by the USDA PLANTS state-level distribution. The parameters $\gamma_{i}$ for the quadratic terms were forced to be negative ('hump-shaped' relationship) or zero (linear relationship on the transformed scale). This restriction prevents a ' $U$ ' shaped relationship between the probability $\pi$ and a predictor $x_{i}$.

Statistical analyses were conducted with GENSTAT (Payne 2009). From the set of candidate predictor variables ( $\mathrm{n}=9$; Supplemental Material 2) a custom procedure (PROPSEARCH) was developed for model selection based on RSEARCH

\section{(https://genstat.kb.vsni.co.uk/knowledge-base/rsearch/). The PROPSEARCH procedure is a} regression selection process, which first selects significant quadratic terms conditional on the presence of all the accompanying linear terms, and then selects significant linear terms which do 
227 not have an accompanying quadratic term. Positive quadratic terms were removed in the first

228 step to avoid a ' $U$ ' shaped relationship. In both selection steps the selected model was the one

229 with the smallest mean deviance for which all terms were significant at the $1 \%$ significance

230 level.

\section{Assessing Model Fit}

The model fit for each species was based on how well the model represented observed occurrence probabilities across all plots in the species' range. For a given species, the selected model was applied to each plot included within the general geographic range for that species.

236 Plot-level estimates of the predictor variables were used as inputs. For each variable, the range

237 between low and high values among plots was split into 20 equal intervals. For example, the $\mathrm{pH}$ 238 range of 4-8 was divided into 20 intervals of $0.2 \mathrm{pH}$ units. For each interval, the average of the 239 predicted occurrence probabilities was calculated. This was compared with the probability 240 derived from the observed data (i.e., the number of occurrences of the species in the interval 241 divided by the number of plots in the interval). goodness of fit statistic for the logistic regression model. The H-L test is almost always

244 significant when the number of observations is large, as is the case with most of the niche models 245 reported here. Therefore, a graphical qualitative version of the H-L test was used to evaluate 246 goodness of fit. This employs a line-plot of cumulative sorted predicted probabilities versus 247 cumulative observed presence/absence values which are sorted in the same way. Large 248 discrepancies between the plotted line and the line $\mathrm{Y}=\mathrm{X}$ are indicative of a lack of fit. 


\section{Derivation of Site-Level Critical Loads with PROPS-CLF}

The PROPS-CLF model (Posch 2017) can be used to generate CLs of N and S deposition from the species models that include at least soil $\mathrm{pH}$ as a predictor variable. Acidifying effects of $\mathrm{N}$ and $\mathrm{S}$ deposition are evaluated in PROPS-CLF using the Simple Mass Balance model (SMB; Posch et al. 2015a). If soil $\mathrm{pH}$ is included as a predictor, but $\mathrm{N}$ deposition is not included, then the resultant CLs only represent acidification effects from deposition. The PROPS-CLF model was used here to develop CLs for indicator understory plants species for the three model application sites (Figure 1). A set of positive indicator plant species considered characteristic of the vegetation association of each site was selected by local botanists (Supplemental Material 3) as described by McDonnell et al. (2018). Critical loads were estimated for specific threshold levels of occurrence probability (i.e., $95 \%, 75 \%$, and $50 \%$ relative to the maximal probability; denoted as CL95, CL75, and CL50 respectively) for each indicator species (i.e., species level) and for the average occurrence probability among all indicator species (i.e., community level) at a given site. Additional details regarding the derivation of CLs using PROPS-CLF can be found in Supplemental Material 4.

The values of $\mathrm{N}$ and $\mathrm{S}$ deposition needed to define the CLF $\left(\mathrm{CLN}_{\max }, \mathrm{CLN}_{\min }, \mathrm{CLS}_{\max }\right.$, $\mathrm{CLS}_{\min }$; Supplemental Material 5) were based on the three occurrence probabilities described above. The CLFs were used to determine CLs of $\mathrm{N}$ deposition under average annual ambient (2014 - 2016) S deposition and CLs of S deposition under average annual ambient $\mathrm{N}$ deposition (http://nadp.slh.wisc.edu/committees/tdep/tdepmaps/). Exceedance of these CLs represent estimates of the extent to which reductions in deposition are needed to protect species diversity. Additionally, CLs were determined under assumed future changes in air temperature of +1.5 and $+3.0^{\circ} \mathrm{C}$, which are within the range of expected future conditions (IPCC 2013). The precipitation regime was not modified because the expected change in future precipitation in the 
274 eastern United States is much more uncertain in magnitude and direction than the change in

275 temperature (USGCRP 2017).

277 Extrapolation Uncertainty

The version of the US-PROPS model reported here calculated leverage scores to use as a metric to describe extrapolation. Leverage scores were used to determine the extent to which the predictor variables associated with a given site were similar to the predictor variable data associated with the set of vegetation survey plots used to develop the response model for a given species. Leverage scores can be used to determine if the derived species model is appropriate for application at a given location. Prior to derivation of CLs for positive indicator species at the HB,

284 PR and CC sites, leverage ratios were determined for each species and site to ensure that sites were characterized by abiotic conditions that are relevant for application of these species niche

286 models (Supplemental Material 3). Low ratios of $L_{\text {site }} / L_{a v}($ e.g. $<2)$ indicate that conditions

287 between the model application site and the calibration dataset are similar.

\section{RESULTS}

\section{Niche Model Development}

Species niche models were developed for 1503 plant species that had at least 50

292 occurrences. The fitting procedure selected variables that had either 1) both a significant linear 293 and a significant quadratic term for the predictor variable or 2) a significant linear term only

294 (Table 1). Because the predictor selection was done separately for each species, not all variables 295 were included in each species model. For example, $\mathrm{N}$ deposition (NDEP30) was selected as a 
296 linear term in 1073 of the 1503 models. This predictor variable was also included as a quadratic 297 term in 646 of these 1073 models.

Nitrogen deposition, soil $\mathrm{pH}$, canopy cover, temperature, and precipitation were most commonly selected. Soil conditions such as clay content and available water content were selected for about half of the species. Rooting depth was a significant variable for less than half

301 of the species. Bell shaped curves (i.e., where the quadratic term, in addition to the linear term, is 302 significant) were most common for $\mathrm{N}$ deposition, precipitation, temperature, solar radiation, 303 canopy cover, soil clay, and soil pH. Available water storage and rooting depth were mostly 304 found to be positively linear related. An example of our assessment of the model fit is shown for Trillium undulatum in Figure 2, where the fitted probabilities are compared with the observed 306 responses for 20 intervals of each predictor variable. This reveals that there is generally close 307 agreement between the average predicted and observed occurrence probability, particularly 308 where more plots are included in the interval (see Supplemental Material 7 for results for the 309 other indicator species). Additionally, continuous H-L test results generally showed good 310 agreement between predicted and observed probability for the selected indicator species, with the exception of Hydrophyllum virginianum (species number = 32010; Supplemental Material 8).

312 This species was retained in the model applications, although results for this species should be 313 considered more uncertain relative to other indicator species.

315 Critical Loads

Species-Level CLs

The lowest species-level CL95 of $\mathrm{N}$ among indicator species at each site was 18, 74, and $31861 \mathrm{meq} / \mathrm{m}^{2} / \mathrm{yr}(2.5,10.3$, and $8.5 \mathrm{~kg} \mathrm{~N} / \mathrm{ha} / \mathrm{yr})$ at HB (T. undulatum), PR (Carya ovata), and CC 
319

320

321

322

323

324

325

326

327

328

329

330

331

332

333

334

335

336

337

338

339

340

(Acer saccharum); respectively. Lowest CL95s of S were 4, 9, and $7 \mathrm{meq} / \mathrm{m}^{2} / \mathrm{yr}(0.6,1.4$, and 1.1

$\mathrm{kg} \mathrm{S} / \mathrm{ha} / \mathrm{yr}$ ) at HB (Maianthemum racemosum), PR (H. virginianum), and CC (Ageratina

altissima); respectively. CL95s of S deposition were generally lower than CL95s of N

deposition. All three sites included two species with CL95 of S deposition less than 18.75

meq $/ \mathrm{m}^{2} / \mathrm{yr}(3.0 \mathrm{~kg} \mathrm{~S} / \mathrm{ha} / \mathrm{yr}$; Table 2).

The majority of the CL95s of $\mathrm{N}$ deposition for individual species under ambient climate conditions were less than $100 \mathrm{meq} / \mathrm{m}^{2} / \mathrm{yr}(14 \mathrm{~kg} \mathrm{~N} / \mathrm{ha} / \mathrm{yr}$; Table 2). Some species, including

Picea rubens, Dryopteris intermedia, T. undulatum, M. racemosum, and A. saccharum showed particularly low $\left(<51 \mathrm{meq} / \mathrm{m}^{2} / \mathrm{yr} ;<7 \mathrm{~kg} \mathrm{~N} / \mathrm{ha} / \mathrm{yr}\right)$ CL95s of $\mathrm{N}$ deposition. The species found to be most insensitive to $\mathrm{N}$ deposition included Fagus grandifolia, Fraxinus americana, Dennstaedtia punctilobula, Oxalis montana, and Quercus rubra.

More species showed moderately low ( $\left.<100 \mathrm{meq} / \mathrm{m}^{2} / \mathrm{yr} ; 16 \mathrm{~kg} \mathrm{~S} / \mathrm{ha} / \mathrm{yr}\right)$ CL95s of S deposition relative to CL95s of N (Table 2). Low CL95s of S deposition $\left(<51 \mathrm{meq} / \mathrm{m}^{2} / \mathrm{yr} ; 8.1 \mathrm{~kg}\right.$ S/ha/yr) were found for Acer pensylvanicum, A. saccharum, A. altissima, C. ovata, F. americana, H. virginianum, Laportea canadensis, M. racemosum, Medeola virginiana, Prunus virginiana, and Quercus alba. In general, indicator species tended to show different levels of sensitivity to S deposition relative to $\mathrm{N}$ deposition.

The extent to which a given CL occurred within or outside the range of $\mathrm{N}$ deposition and soil $\mathrm{pH}$ that was used to develop the species models was often dependent on the specified percentage of maximum occurrence probability for which the CL was determined. For example, the CL75 for T. undulatum was within the bounds of model input data, whereas the CL95 to was outside these bounds (Figure 3; see Supplemental Material 9 for analogous CLF plots for all 
341 indicator species). Species-level CL75s and CL50s were considerably higher than CL95s

342 (Supplemental Material 10).

\section{Community Level CLs}

The CL95 across all indicator species was lowest at HB (60 meq/m²/yr; $8.5 \mathrm{~kg} \mathrm{~N} / \mathrm{ha} / \mathrm{yr}$;

Supplemental Material 11). Critical loads of S deposition for all indicator species combined were generally lower than CLs of $\mathrm{N}$ deposition.

\section{Effects of Increased Temperature on CLs}

Scenarios of increased temperature $\left(+1.5^{\circ} \mathrm{C}\right.$ and $\left.+3{ }^{\circ} \mathrm{C}\right)$ had variable effects on the

351 species-level CL95s determined under ambient temperature conditions (Table 2). CL95s of N

352 deposition at HB generally decreased under both temperature scenarios and these deviations

353 were almost always less than $10 \mathrm{meq} / \mathrm{m}^{2} / \mathrm{yr}(1.4 \mathrm{~kg} \mathrm{~N} / \mathrm{ha} / \mathrm{yr})$. Differences in CL95s of N

354 deposition at PR were almost always $+/-6 \mathrm{meq} / \mathrm{m}^{2} / \mathrm{yr}(0.8 \mathrm{~kg} \mathrm{~N} / \mathrm{ha} / \mathrm{yr})$. A. pensylvanicum at CC

355 showed decreases of $28 \mathrm{meq} / \mathrm{m}^{2} / \mathrm{yr}(3.9 \mathrm{~kg} \mathrm{~N} / \mathrm{ha} / \mathrm{yr})$ and $38 \mathrm{meq} / \mathrm{m}^{2} / \mathrm{yr}(5.3 \mathrm{~kg} \mathrm{~N} / \mathrm{ha} / \mathrm{yr})$ under the

356 two warming scenarios. CL95s of $\mathrm{N}$ were not attainable for four species under a warming

357 scenario of $+3{ }^{\circ} \mathrm{C}$. CL95s of S deposition under scenarios of increased air temperature followed 358 similar patterns to those of $\mathrm{N}$ deposition.

\section{Exceedances}

The CLs reported in our study represent estimates of the deposition load expected to

362 result in a specific occurrence probability under steady-state conditions. Exceedance of the CL

363 indicates that species occurrence is vulnerable to effects from $\mathrm{N}$ and/or $\mathrm{S}$ deposition. With 
ambient $\mathrm{N}$ deposition equal to 36,65 , and $54 \mathrm{meq} / \mathrm{m}^{2} / \mathrm{yr}$ at $\mathrm{HB}$, PR, and CC; respectively, community level CL95s of $\mathrm{N}$ deposition were not exceeded under ambient deposition conditions (Supplemental Material 11). However, individual species CL95s of N were in exceedance at HB (Table 2). Ambient $\mathrm{S}$ deposition at HB, PR and CC was 17, 20, and $19 \mathrm{meq} / \mathrm{m}^{2} / \mathrm{yr}$ at $\mathrm{HB}$, PR, and CC, respectively. CL95s of S deposition for all indicator species were only exceeded at CC (Supplemental Material 11). At least one species at all three model sites received S deposition that was in exceedance of its CL95 (Table 2). Exceedance of CLs of S effectively indicates that no additional acidifying $\mathrm{N}$ deposition is allowable if the goal is to provide resource protection.

Although a $1.5^{\circ} \mathrm{C}$ increase in future air temperature is expected to generally result in lower CL95s of N and S deposition (Table 2 and Supplemental Material 11), these lower CL values typically remained sufficiently high to avoid exceedance. The specified occurrence probability for $L$. canadensis under ambient climate was not possible to attain with a $1.5^{\circ} \mathrm{C}$ increase in air temperature at the $\mathrm{CC}$ site, regardless of the level of $\mathrm{N}$ or $\mathrm{S}$ deposition at that site. An increase in air temperature of $3.0^{\circ} \mathrm{C}$ caused a decrease in the maximum occurrence probability to such an extent that it would no longer be possible to attain the specified level of occurrence under ambient climate for the combined set of indicator species at $\mathrm{HB}$ and $\mathrm{CC}$ and also for several individual species among all model application sites, regardless of the level of $\mathrm{N}$ or S deposition. Although there were no additional species in exceedance of the CL95 of N at any of the sites, there were three additional exceedances of CL95s of S at PR (C. ovata, P. virginiana, $Q$. alba $)$ and two additional ones at $\mathrm{CC}(A$. saccharum and $M$. racemosum) under a warming scenario of $3.0^{\circ} \mathrm{C}$. 


\section{DISCUSSION}

Forest understory plant communities are sensitive to $\mathrm{N}$ and $\mathrm{S}$ input and other drivers of ecological change, but the response can be highly variable within and among species and sites. We found that some species have relatively high CLs (insensitive to $\mathrm{N}$ and/or S deposition) whereas others have low CLs, suggesting high sensitivity to $\mathrm{N}$ and/or $\mathrm{S}$ deposition. Furthermore, species-level CLs were dependent on site conditions. A. pensylvanicum was selected as an indicator species at all three model sites. Critical loads of $\mathrm{N}$ and $\mathrm{S}$ deposition for $A$. pensylvanicum were substantially lower at $\mathrm{HB}$ relative to $\mathrm{PR}$ and $\mathrm{CC}$. Indicator species $A$. saccharum and M. racemosum occurred at both HB and CC and the CLs for these two species were also lower at HB. Site conditions at PR led to lower CLs for F. americana relative to HB. These differences in species-level CLs among sites were attributed, in part, to considerably lower rates of base cation inputs to buffer acidifying $\mathrm{N}$ and $\mathrm{S}$ deposition at $\mathrm{HB}$, in conjunction with species niche preferences, which illustrates the importance of including site characteristics other than $\mathrm{N}$ and $\mathrm{S}$ deposition in CL determination for understory species (cf., Clark et al. 2019). This site dependency of CL values provides a greater level of specificity in the spatial context of species-level CLs relative to other empirical approaches (Horn et al. 2018) and is an important consideration with respect to natural resource management.

Perring et al. (2018) characterized the dependencies of $\mathrm{N}$ response on ecosystem characteristics as driven by the amount and form of available $\mathrm{N}$, cumulative $\mathrm{N}$ input over many decades, role(s) of the overstory, and seed or propagule availability. They noted that $\mathrm{N}$ input can also affect impacts attributable to surrounding landscape conditions such as animal browsing and various aspects of site management (e.g., logging, soil compaction, herbicide use, etc.). Such additional factors (not included in our analysis) can complicate efforts to predict the response to 
$410 \mathrm{~N}$ deposition of understory plant communities and how best to conserve understory plant

411 biodiversity. Nevertheless, our approach addresses many of the primary drivers of plant

412 occurrence through the use of nine predictor variables representing aspects of climate, light

413 availability, soil nutrient availability, moisture, and depth. Inclusion of light availability is

414 particularly noteworthy given its importance to species occurrence.

415 Targeted field studies designed to evaluate effects of $\mathrm{N}$ and $\mathrm{S}$ deposition on the sensitive 416 species identified in this study would contribute to model validation. Furthermore, CLs were

417 determined from the soil $\mathrm{pH}$ response in conjunction with a mass balance model (i.e., SMB) to

418 derive the sustained rate of deposition expected to result in a given soil $\mathrm{pH}$. Uncertainty in the

419 steady state $\mathrm{pH}$ computed by the SMB model is driven by uncertainties in the input data, which

420 may be quantifiable with a Monte Carlo style analysis in a future study. As such, the specific

421 CLs reported here should be considered as preliminary estimates of the CL and not the precise

422 level of deposition that corresponds with the specified occurrence probability for a given species.

423 Critical loads of S deposition for some species were close to estimates of background S

424 deposition (1 to $3 \mathrm{~kg} \mathrm{~S} / \mathrm{ha} / \mathrm{yr}$; Husar et al. 1991). The values of CL95 of S were determined based

425 on the critical load functions according to the ambient rate of $\mathrm{N}$ deposition $(2014-2016$

426 average; Supplemental Material 10). Under the steady-state conditions assumed by the PROPS-

427 CLF model, incoming $\mathrm{N}$ deposition affects soil $\mathrm{pH}$ and associated species occurrence probability

428 on balance with $\mathrm{N}$ removals and the net input of base cations (Table SM4-1). As such, the

429 acidifying effect of $\mathrm{N}$ deposition under steady-state conditions influences the CL95 of S and in

430 some cases results in low (i.e., near background) values of CL95 of S for acid-sensitive species

431 at the two relatively poorly buffered sites (HB and CC). 
Initial comparisons of our results with a nationwide assessment that used a different but

433

434

435

436

437

438

439

440

441

442

443

444

445

446

447

448

449

450

451

452

453

454

related methodology (Clark et al. 2019) suggest some agreement. Clark et al. (2019) used GLM logistic regression for a subset of 348 herbaceous species, but did not constrain the quadratic $\mathrm{N}$ relationships to be negative. Of the 18 unique indicator species in our study, 11 were in common across studies. This was because tree species, as seedlings in the understory, were included as indicator species in our study, whereas Clark et al. (2019) focused on herbaceous species. Of the 11 herbaceous species that overlapped, only two were highlighted in Clark et al. (2019) as having "robust" relationships (i.e., $\mathrm{R}^{2}>0.1$, Area Under the $\mathrm{ROC}$ curve $>0.7$; H. virginianum and T. borealis). The CLs for H. virginianum were comparable (i.e., CL of 20.4 and $1.4 \mathrm{~kg} \mathrm{ha}^{-1}$ $\mathrm{yr}^{-1}$ for $\mathrm{N}$ and $\mathrm{S}$, respectively, in this study compared with $\mathrm{CL}>18.9$ and $<0.4 \mathrm{ha}^{-1} \mathrm{yr}^{-1}$ for $\mathrm{N}$ and S, respectively, in Clark et al. (2019). The CLs for T. borealis were somewhat lower in Clark et al. (2019) for $\mathrm{N}$ and similar for $\mathrm{S}$ (i.e., $\mathrm{CL}$ of $8.4 \mathrm{~kg} \mathrm{~N} \mathrm{ha}^{-1} \mathrm{yr}^{-1}$ in this study versus $4.8-7.2 \mathrm{~kg} \mathrm{~N}$ $\mathrm{ha}^{-1} \mathrm{yr}^{-1}$ in Clark et al. (2019); and $>48 \mathrm{~kg} \mathrm{~S} \mathrm{ha}^{-1} \mathrm{yr}^{-1}$ in this study and $>\sim 39 \mathrm{~S} \mathrm{ha}^{-1} \mathrm{yr}^{-1}$ in Clark et al. (2019). The nine other species were not highlighted in Clark et al. (2019) because of either non-robust models (one species) or U-shaped relationships (eight species). Although U-shaped relationships were relatively uncommon in Clark et al. $(2019 ; \sim 18 \%$ of species $)$, it can be important to constrain relationships to those that are ecologically realistic.

According to the CLs reported here, the species most sensitive to $\mathrm{N}$ deposition are $T$. undulatum, P. rubens and D. intermedia. All three are insensitive to S deposition. Insensitivity to $\mathrm{S}$ deposition is expected for T. undulatum and D. intermedia since these species are typically associated with acidic soils (eFloras 2019, Zarfos et al. 2019). Although P. rubens is known to be sensitive to elevated S deposition (U.S. EPA 2008), steady-state conditions at these sites are favorable for $P$. rubens seedlings even with relatively high $\mathrm{S}$ deposition. All three species grow 
455 on relatively nutrient-poor soils, which is in agreement with their low CL of $\mathrm{N}$ as determined by

456 PROPS-CLF. The five species with relatively high CLs of $\mathrm{N}$ tend to be associated with

457 disturbance or mature forests. High CLs of S for O. montana and F. grandifolia are expected

458 given the preference these species have for acidic soils (eFloras 2019).

Maximum occurrence probabilities for many individual indicator species often occurred

460 at or near zero $\mathrm{S}$ deposition, particularly at the $\mathrm{CC}$ site. This suggests that these species are

461 sensitive to any amount of acidification. These species generally prefer higher soil $\mathrm{pH}$ conditions

462 than are found at these sites and they are in exceedance of the CL to attain relative plant

463 occurrence probabilities $>95 \%$. Decreases in S deposition beyond the ambient $(2014-2016$

464 average) level of S deposition would likely benefit their long-term occurrence probability at

465 these sites.

The approach used here for niche model development included several improvements for

467 addressing uncertainty in CL results:

1) constraining input data for model development to only those vegetation plots contained within the known geographic range for each species,

2) generating Hosmer-Lemeshow test results for checking goodness of fit,

3) developing graphical depictions of one-dimensional model fits based on modeled vs. observed occurrence probability, and

4) determining the leverage ratio to characterize the difference between the abiotic conditions used for niche model development and those that occur at a given PROPSCLF model application site.

477 McDonnell et al. (2018) that are important for establishing management and policy relevant CL 
478 results. Improvement 1 allows for more confidence in CL results that are outside the bounds of

479 niche model input data. This is because the multi-dimensional response surface extends the

480 trajectory that occurs at the edge of the available input data, rather than being forced to zero due

481 to "pseudo-absences" as was the case with the previous version of these niche models

482 (McDonnell et al. 2018). Nevertheless, predicted CLs beyond the bounds of observed N

483 deposition and soil $\mathrm{pH}$ ranges should be considered more uncertain that those that are found

484 within these bounds. Improvements 2 and 3 provide information on how well the model is able

485 to reproduce the occurrence probability derived from the observed data set. Improvement 4

486 provides a mechanism to ensure that the niche models are appropriately used for CL

487 development at a given site. Future iterations of these niche models should focus on additional

488 model confirmation steps, including comparisons of predicted and observed occurrence

489 probabilities at plots not used for model development. Model results shown here also provide a

490 basis for understanding which species are expected to be most susceptible to increases in $\mathrm{N}$ and $\mathrm{S}$

491 deposition. These results can be used as guidance for establishing targeted field-based studies of

$492 \mathrm{~N}$ and $\mathrm{S}$ deposition effects on individual species.

There is a strong potential for the modeling approach described here to be developed for

494 evaluating individual or synergistic effects of future scenarios related to changes in air

495 temperature, precipitation, atmospheric $\mathrm{N}$ and/or $\mathrm{S}$ deposition, tree harvesting regime or other

496 potential forest disturbance agents (e.g., pests, windthrow, fire, drought). Future work may

497 include incorporation of seasonality in climate metrics, which may be particularly important for

498 western United States species that occur in areas with relatively high amounts of annual

499 precipitation, but experience drought conditions in the summer. For these species, the length of

500 summer drought may be a more important driver of plant response than total annual 
501 precipitation. This would also provide the ability to simulate impacts of future climate based on 502 seasonal (rather than annual) changes, which is relevant given that future climate is not expected 503 to change uniformly across all seasons (IPCC 2013). Future work may also evaluate various 504 approaches to estimating species-level CLs (e.g., TITAN as in Payne et al. (2013), partial 505 derivatives as in Clark et al. (2019), and PROPS-CLF as shown here). Such a multi-model study 506 implemented at a regional scale could provide an opportunity for estimating uncertainty in the 507 CL estimates for a given species or vegetation association. The CLs that align more closely 508 among the approaches may have higher certainty relative to CLs that diverge. Furthermore, it 509 may be possible to identify opportunities for synergy in such a study. The logistic species model 510 used here employed linear and quadratic effects for several predictor variables. Alternative

511 models might include interactions between predictor variables or employ more flexible 512 smoothing splines instead of quadratic models.

\section{CONCLUSIONS}

Significant advancements towards development of management and policy relevant

516 biodiversity-based CLs have been made. The revised species niche models presented in this

517 study expand on previous research by increasing the number of species, incorporating additional 518 explanatory variables, and addressing goodness of fit and uncertainty. The site-level applications 519 of PROPS-CLF demonstrate the use of these revised niche models for addressing effects of 520 atmospheric $\mathrm{N}$ and $\mathrm{S}$ deposition at the local scale. The modeling approaches described here can 521 also be used at a regional scale to evaluate individual or synergistic effects of multiple 522 disturbance types on species occurrence probability and for understanding spatial patterns in air 523 pollution effects thresholds. 
ACKNOWLEDGEMENTS

Model input data were provided by S. Simkin and the USDA Forest Service, Forest

Inventory and Analysis Program (R. McCullough, B. Shultz). This research was conducted with

funding from the U.S. Environmental Protection Agency through a contract with E\&S

Environmental Chemistry, Inc (EP-17-C-000083). The views expressed in this article are those

of the authors and do not necessarily represent the views or policies of the U.S. Environmental

Protection Agency.

\section{REFERENCES}

534

535

536

537

538

539

540

541

542

543

544

545

546

547

548

549

550

551

552

553

554

555

556

557

558

Austin, M.P. and K.P. Van Niel. 2011. Improving species distribution models for climate change studies: variable selection and scale. J. Biogeogr. 38(1):1-8. 10.1111/j.13652699.2010.02416.x.

Bobbink, R. and W.K. Hicks. 2014. Factors affecting nitrogen deposition impacts on biodiversity: An overview. In: Sutton, M.A., K.E. Mason, L.J. Sheppard, H. Sverdrup, R. Haeuber and W.K. Hicks (Eds.). Nitrogen Deposition, Critical Loads and Biodiversity. Springer Netherlands, Dordrecht. pp. 127-138.

Bobbink, R., K. Hicks, J. Galloway, T. Spranger, R. Alkemade, M. Ashmore, M. Bustamante, S. Cinderby, E. Davidson, F. Dentener, B. Emmett, J.-W. Erisman, M. Fenn, F.S. Gilliam, A. Nordin, L. Pardo, and W. de Vries. 2010. Global assessment of nitrogen deposition effects on terrestrial plant diversity: a synthesis. Ecol. Appl. 20:30-59.

Bonten, L.T.C., G.J. Reinds, and M. Posch. 2016. A model to calculate effects of atmospheric deposition on soil acidification, eutrophication and carbon sequestration. Environ. Model. Software 79:75-84. 10.1016/j.envsoft.2016.01.009.

Bowman, W.D., J. Murgel, T. Blett, and E. Porter. 2012. Nitrogen critical loads for alpine vegetation and soils in Rocky Mountain National Park. J. Environ. Manage. 103:165-171.

Bréda, N., R. Huc, A. Granier, and E. Dreyer. 2006. Temperate forest trees and stands under severe drought: a review of ecophysiological responses, adaptation processes and longterm consequences. Ann. For. Sci. 63(6):625-644.

Chen, D., Z. Lan, X. Bai, J.B. Grace, and Y. Bai. 2013. Evidence that acidification-induced declines in plant diversity and productivity are mediated by changes in below-ground communities and soil properties in a semi-arid steppe. J. Ecol. 101(5):1322-1334. 10.1111/1365-2745.12119.

Clark, C.M. and D. Tilman. 2008. Loss of plant species after chronic low-level nitrogen deposition to prairie grasslands. Nature 451:712-715. 
Clark, C.M., E.E. Cleland, S.L. Collins, J.E. Fargione, L. Gough, K.L. Gross, S.C. Pennings, K.N. Suding, and J.B. Grace. 2007. Environmental and plant community determinants of species loss following nitrogen enrichment. Ecol. Lett. 10:596-607.

Clark, C.M., S.M. Simkin, E.B. Allen, W.D. Bowman, J. Belnap, M.L. Brooks, S.L. Collins, L.H. Geiser, F.S. Gilliam, S.E. Jovan, L.H. Pardo, B.K. Schulz, C.J. Stevens, K.N. Suding, H. L.Throop, and D.M. Waller. 2019. Potential vulnerability of 348 herbaceous species to atmospheric deposition of nitrogen and sulfur in the U.S. Nature Plants 5: 697705. 10.1038/s41477-019-0442-8.

de Vries, W., G.W.W. Wamelink, H. van Dobben, J. Kros, G.J. Reinds, J.P. Mol-Dukstra, S.M. Smart, C.D. Evans, E.C. Rowe, S. Belyazid, H.U. Sverdrup, A. van Hinsberg, M. Posch, J.-P. Hettelingh, T. Spranger, and R. Bobbink. 2010. Use of dynamic soil-vegetation models to assess impacts of nitrogen deposition on plant species composition: an overview. Ecol. Appl. 20(1):60-79.

eFloras. 2019. Missouri Botanical Garden, St. Louis, MO \& Harvard University Herbaria, Cambridge, MA. Available at: http://www.efloras.org [accessed 1/22/2019].

Galloway, J.N., A.R. Townsend, J.W. Erisman, Bekunda, C. Z., J.R. Freney, L.A. Martinelli, S.P. Seitzinger, and M.A. Sutton. 2008. Transformation of the nitrogen cycle: recent trends, questions, and potential solutions. Science 320:889-892.

Gilliam, F.S. 2007. The ecological significance of the herbaceous layer in temperate forest ecosystems. BioScience 57(10):845-858.

Hautier, Y.R., P.A. Niklaus, and A. Hector. 2009. Competition for light causes plant biodiversity loss after eutrophication. Science 324:636-638.

Hettelingh, J.-P., M. Posch, and J. Slootweg (Eds.). 2017. European critical loads: database, biodiversity and ecosystems at risk, CCE Final Report 2017. National Institute for Public Health and the Environment, Bilthoven, the Netherlands.

Horn, K.J., R.Q. Thomas, C.M. Clark, L.H. Pardo, M.E. Fenn, G.B. Lawrence, S.S. Perakis, E.A.H. Smithwick, D. Baldwin, S. Braun, A. Nordin, C.H. Perry, J.N. Phelan, P.G. Schaberg, S.B. St. Clair, R. Warby, and S. Watmough. 2018. Growth and survival relationships of 71 tree species with nitrogen and sulfur deposition across the conterminous U.S. PLoS One 13(10). 10.1371/journal.pone.0205296.

Hosmer, D.W. and S. Lemeshow. 2000. Applied Logistic Regression (2nd Edition). John Wiley \& Sons, New York.

Husar, R.B., T.J. Sullivan, and D.F. Charles. 1991. Historical trends in atmospheric sulfur deposition and methods for assessing long-term trends in surface water chemistry. In: Charles, D.F. (Ed.) Acidic Deposition and Aquatic Ecosystems: Regional Case Studies. Springer-Verlag, New York. pp. 65-82.

Intergovernmental Panel on Climate Change (IPCC). 2013. Climate Change 2013: The Physical Science Basis. Contribution of Working Group I to the Fifth Assessment Report of the Intergovernmental Panel on Climate Change. (Stocker, T.F., D. Qin, G.-K. Plattner, M. Tignor, S.K. Allen, J. Boschung, A. Nauels, Y. Xia, V. Bex and P.M. Midgley [Eds.]). In: Cambridge University Press, Cambridge, United Kingdom \& New York, NY, USA.

Kraft, N.J.B., P.B. Adler, O. Godoy, E.C. James, S. Fuller, and J.M. Levine. 2015. Community assembly, coexistence and the environmental filtering metaphor. Funct. Ecol. 29(5):592599. 10.1111/1365-2435.12345. 
McDonnell, T.C., S. Belyazid, T.J. Sullivan, H. Sverdrup, W.D. Bowman, and E.M. Porter. 2014. Modeled subalpine plant community response to climate change and atmospheric nitrogen deposition in Rocky Mountain National Park, USA. Environ. Pollut. 187:55-64. McDonnell, T.C., G.J. Reinds, T.J. Sullivan, C.M. Clark, L.T.C. Bonten, J.P. Mol-Dijkstra, G.W.W. Wamelink, and M. Dovciak. 2018. Feasibility of coupled empirical and dynamic modeling to assess climate change and air pollution impacts on temperate forest vegetation of the eastern United States. Environ. Pollut. 234:902-914. 10.1016/j.envpol.2017.12.002.

Millennium Ecosystem Assessment (MEA). 2005. Ecosystems and Human Well-Being: The Assessment Series (Four Volumes and Summary). Island Press, Washington, DC.

Nilsson, J. and P. Grennfelt. 1988. Critical Loads for Sulphur and Nitrogen. Miljorapport 1988:15. Nordic Council of Ministers, Copenhagen.

Payne, R.J., N.B. Dise, C.J. Stevens, and D.J. Gowing. 2013. Impact of nitrogen deposition at the species level. Proc. Nat. Acad. Sci. 110:984-987.

Payne, R.W. 2009. Genstat. WIREs Computational Statistics 1:255-258.

Perring, M.P., M. Diekmann, G. Midolo, D.S. Costa, M. Bernhardt-Römermann, J.C.J. Otto, F.S. Gilliam, P.-O. Hedwall, A. Nordin, T. Dirnböck, S.M. Simkin, F. Máliš, H. Blondeel, J. Brunet, M. Chudomelová, T. Durak, P. De Frenne, R. Hédl, M. Kopecký, D. Landuyt, D. Li, P. Manning, P. Petř́k, K. Reczyńska, W. Schmidt, T. Standovár, K. Świerkosz, O. Vild, D.M. Waller, and K. Verheyen. 2018. Understanding context dependency in the response of forest understorey plant communities to nitrogen deposition. Environ. Pollut. 10.1016/j.envpol.2018.07.089.

Phelan, J., S. Belyazid, P. Jones, J. Cajka, J. Buckley, and C. Clark. 2016. Assessing the effects of climate change and air pollution on soil properties and plant diversity in sugar maplebeech-yellow birch hardwood forests in the northeastern United States: Model simulations from 1900-2100. Water Air Soil Pollut. 227:84.

Posch, M. 2017. PROPS-CLF User Manual. Version 1.4. Coordination Centre for Effects, National Institute for Public Health and the Environment, Bilthoven, The Netherlands.

Posch, M., W. de Vries, and H.U. Sverdrup. 2015a. Mass balance models to derive critical loads of nitrogen and acidity for terrestrial and aquatic ecosystems. In: de Vries, W., J.-P. Hettelingh and M. Posch (Eds.). Critical Loads and Dynamic Risk Assessments. Nitrogen, Acidity, and Metals in Terrestrial and Aquatic Ecosystems. Environmental Pollution 25. Springer, Dordrecht. pp. 171-205.

Posch, M., J.-P. Hettelingh, J. Slootweg, and G.J. Reinds. 2015b. Critical loads for plant species diversity. In: Slootweg, J., M. Posch and J.P. Hettelingh (Eds.). Modelling and Mapping the Impacts of Atmospheric Deposition of Nitrogen and Sulphur. CCE Status Report 2015. National Institute for Public Health and the Environment, Bilthoven, the Netherlands. pp. 45-54.

Reinds, G.J., J. Mol-Dijkstra, L. Bonten, W. Wamelink, W. deVries, and M. Posch. 2014. VSD+PROPS: Recent developments. Chapter 4. In: Slootweg, J., M. Posch, J.-P. Hettelingh and L. Mathijssen (Eds.). Modelling and Mapping the Impacts of Atmospheric Deposition on Plant Species Diversity in Europe. CCE Status Report 2014. National Institute for Public Health and the Environment, Bilthoven, The Netherlands. pp. 47-53.

Schulz, B.K. and K. Dobelbower. 2012. Short Database Report: FIADB Vegetation Diversity and Structure Indicator (VEG. In: Dengler, J., J. Oldeland, F. Jansen, M. Chytrý, J. 
Ewald, M. Finckh, F. Glöckler, G. Lopez-Gonzalez, R.K. Peet and J.H.J. Schaminée (Eds.). Vegetation Databases for the 21st Century. Biodiversity \& Ecology. 4:436. Simkin, S.M., E.B. Allen, W.D. Bowman, C.M. Clark, J. Belnap, M.L. Brooks, B.S. Cade, S.L. Collins, L.H. Geiser, F.S. Gilliam, S.E. Jovan, L.H. Pardo, B.K. Schulz, C.J. Stevens, K.N. Suding, H.L. Throop, and D.M. Waller. 2016. Conditional vulnerability of plant diversity to atmospheric nitrogen deposition across the United States. Proc. Nat. Acad. Sci. 113(15):4086-4091. 10.1073/pnas.1515241113.

Slootweg, J., M. Posch, and J.-P. Hettelingh (Eds.). 2015. Modelling and mapping the impacts of atmospheric deposition of nitrogen and sulphur: CCE Status Report 2015. National Institute for Public Health and the Environment, Bilthoven, the Netherlands.

Stevens, C.J. 2016. How long do ecosystems take to recover from atmospheric nitrogen deposition? Biol. Cons. 200:160-167. 10.1016/j.biocon.2016.06.005.

Stevens, C.J., K. Thompson, J.P. Grime, C.J. Long, and D.J.G. Gowing. 2010a. Contribution of acidification and eutrophication to declines in species richness of calcifuge grasslands along a gradient of atmospheric nitrogen deposition. Funct. Ecol. 24(2):478-484. 10.1111/j.1365-2435.2009.01663.x.

Stevens, C.J., C. Duprè, E. Dorland, C. Gaudnik, D.J.G. Gowing, A. Bleeker, M. Diekmann, D. Alard, R. Bobbink, D. Fowler, E. Corcket, J.O. Mountford, V. Vandvik, P.A. Aarrestad, S. Muller, and N.B. Dise. 2010b. Nitrogen deposition threatens species richness of grasslands across Europe. Environ. Pollut. 158(9):2940-2945. 10.1016/j.envpol.2010.06.006.

Suddick, E.C., P. Whitney, A.R. Townsend, and E.A. Davidson. 2013. The role of nitrogen in climate change and the impacts of nitrogen-climate interactions in the United States: foreword to thematic issue. Biogeochemistry 114(1):1-10. 10.1007/s 10533-012-9795-z.

Sullivan, T.J. 2012. Combining ecosystem service and critical load concepts for resource management and public policy. Water 4:905-913. 10.3390/w4040905.

Sullivan, T.J. 2017. Air Pollution and Its Impacts on U.S. National Parks. CRC Press, Boca Raton, FL. 638 pp.

Sullivan, T.J., C.T. Driscoll, C.M. Beier, D. Burtraw, I.J. Fernandez, J.N. Galloway, D.A. Gay, C.L. Goodale, G.E. Likens, G.M. Lovett, and S.A. Watmough. 2018. Air pollution success stories in the United States: The value of long-term observations. Environ. Sci. Policy 84:69-73. 10.1016/j.envsci.2018.02.016.

U.S. Environmental Protection Agency (U.S. EPA). 2008. Integrated Science Assessment for Oxides of Nitrogen and Sulfur -- Ecological Criteria. EPA/600/R-08/082F. National Center for Environmental Assessment, Office of Research and Development, Research Triangle Park, NC.

U.S. Environmental Protection Agency (U.S. EPA). 2009. Risk and Exposure Assessment for Review of the Secondary National Ambient Air Quality Standards for Oxides of Nitrogen and Oxides of Sulfur: Final. EPA-452/R-09-008a. Office of Air Quality Planning and Standards, Health and Environmental Impacts Division, Research Triangle Park, NC.

U.S. Global Change Research Program. 2017. Climate Science Special Report: Fourth National Climate Assessment, Volume I. U.S. Global Change Research Program, Washington, DC, USA. 470 pp.

van Dobben, H.F. and W. de Vries. 2017. The contribution of nitrogen deposition to the eutrophication signal in understorey plant communities of European forests. Ecology and Evolution 7:214-227. 10.1002/ece3.2485. 
Vanderhorst, J.P., E.A. Byers, and B.P. Streets. 2012. Short database report: Natural Heritage Vegetation Database for West Virginia. In: Dengler, J., J. Oldeland, F. Jansen, M. Chytrý, J. Ewald, M. Finckh, F. Glöckler, G. Lopez-Gonzalez, R.K. Peet and J.H.J. Schaminée (Eds.). Vegetation Databases for the 21st Century. Biodiversity \& Ecology. $4: 440$.

Wamelink, G.W.W., P.W. Goedhart, A.H. Malinowska, J.Y. Frissel, R.J.M. Wegman, P.A. Slim, and H.F. van Dobben. 2011. Ecological ranges for the $\mathrm{pH}$ and $\mathrm{NO}_{3}$ of syntaxa: a new basis for the estimation of critical loads for acid and nitrogen deposition. J. Veg. Sci. 22(4):741-749. 10.1111/j.1654-1103.2011.01286.x.

Webb, R.S., C.E. Rosenzweig, and E.R. Levine. 1993. Specifying land surface characteristics in general circulation models: Soil profile data set and derived water-holding capacities. Glob. Biogeochem. Cycles 7(1):97-108. 10.1029/92gb01822.

Zarfos, M.R., M. Dovciak, G.B. Lawrence, T.C. McDonnell, and T.J. Sullivan. 2019. Plant richness and composition in hardwood forest understories vary along an acidic deposition and soil-chemical gradient in the northeastern United States. Plant Soil. https://doi.org/10.1007/s11104-019-04031-y. 


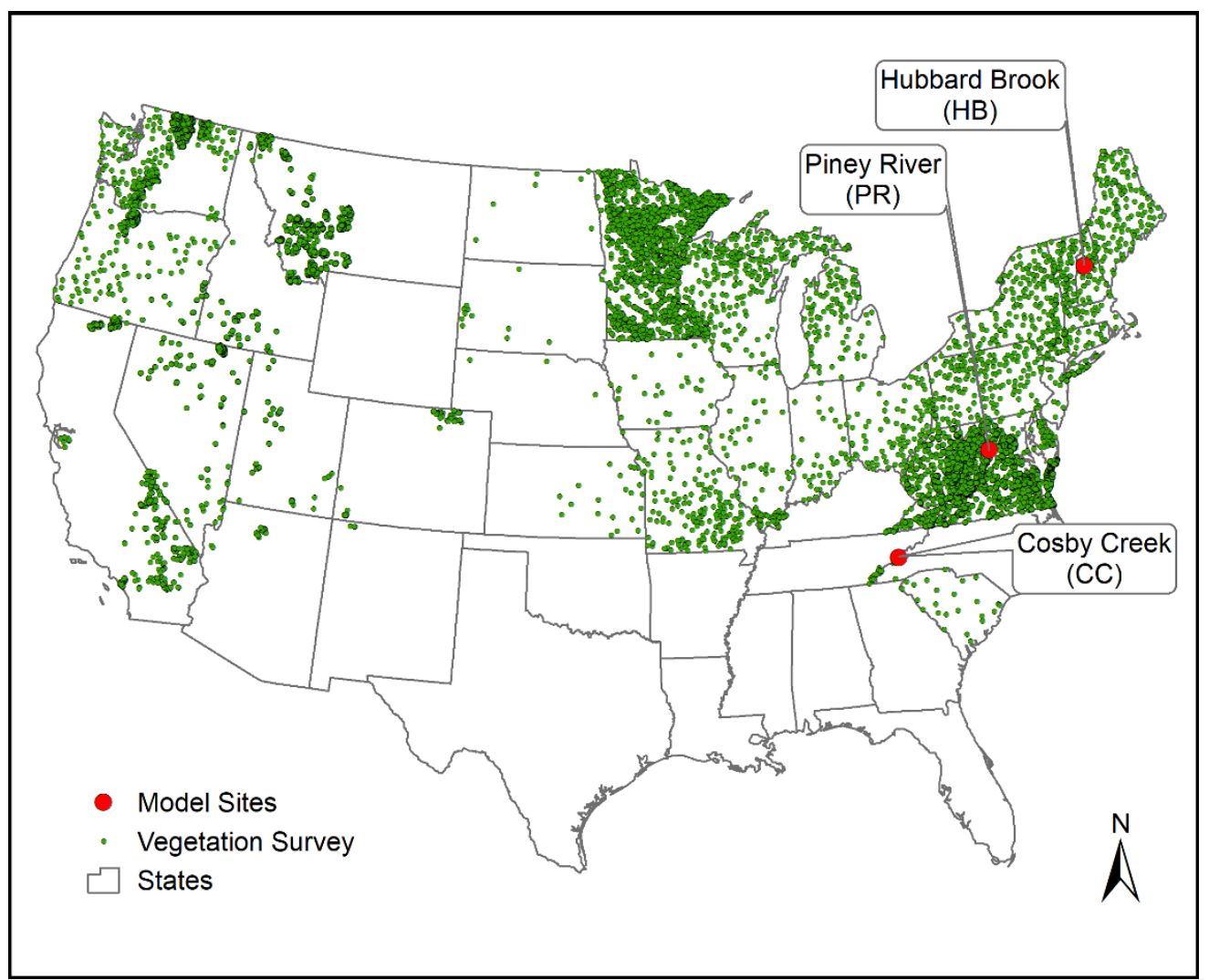

Figure 1. Location of vegetation survey plots used as the basis for deriving species niche models. For map display purposes, the USDA Forest Service's Forest Inventory and Analysis (FIA) plots were based on perturbed and swapped (i.e., publicly available) coordinates. 
- Observed - Modelled
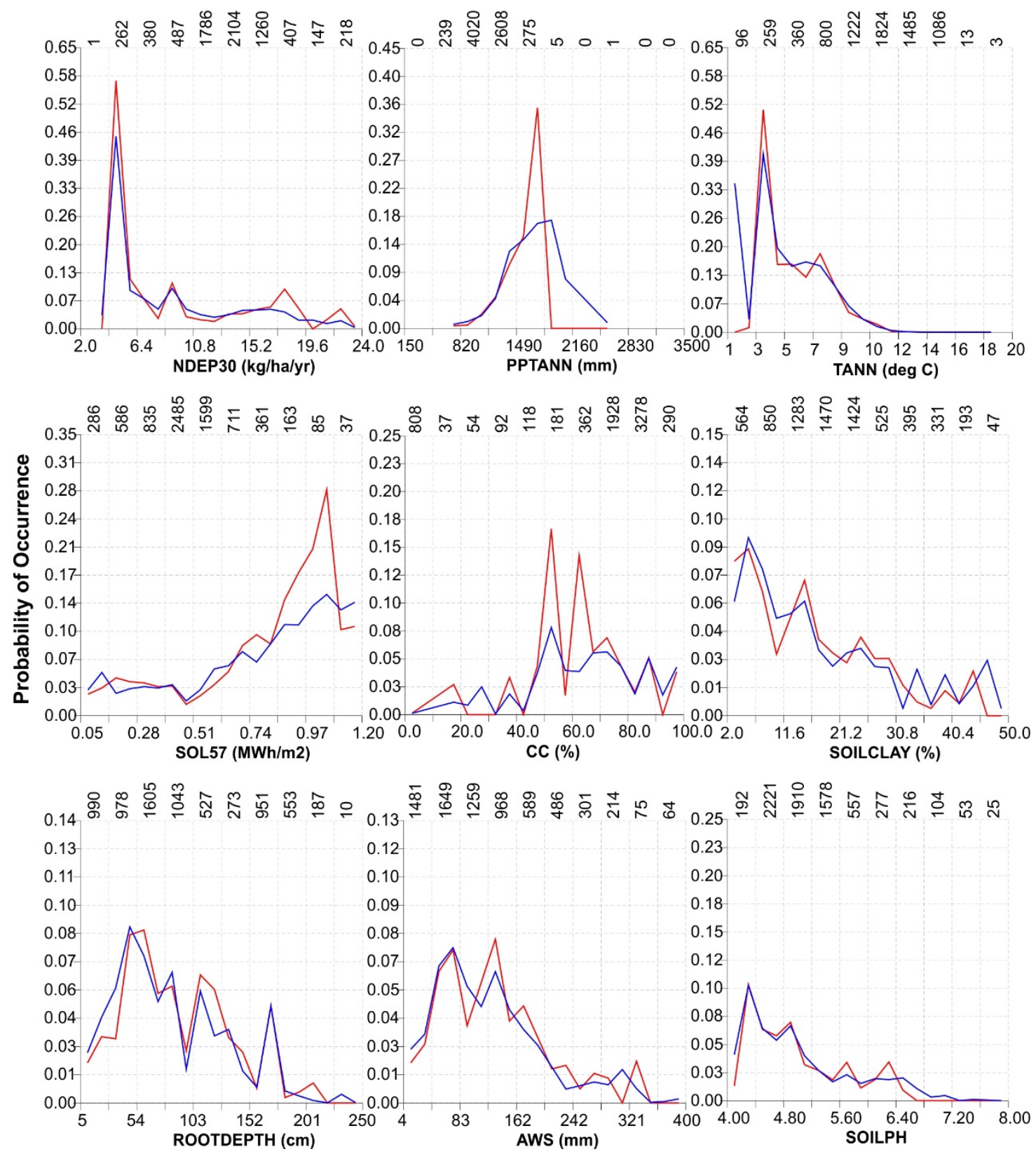

Figure 2. Example one-dimensional model fits for the indicator species Trillium undulatum. Each predictor variable was divided into 20 equal intervals. The average observed occurrence (blue line) and average modeled occurrence probability (red line) within each interval are shown. These lines represent linear interpolations between average (point) values for each interval. The numbers written vertically above each plot indicate the total number of vegetation surveys included in each column shown on the plot. HosmerLemeshow test results for this species are shown in Supplemental Material 8. 


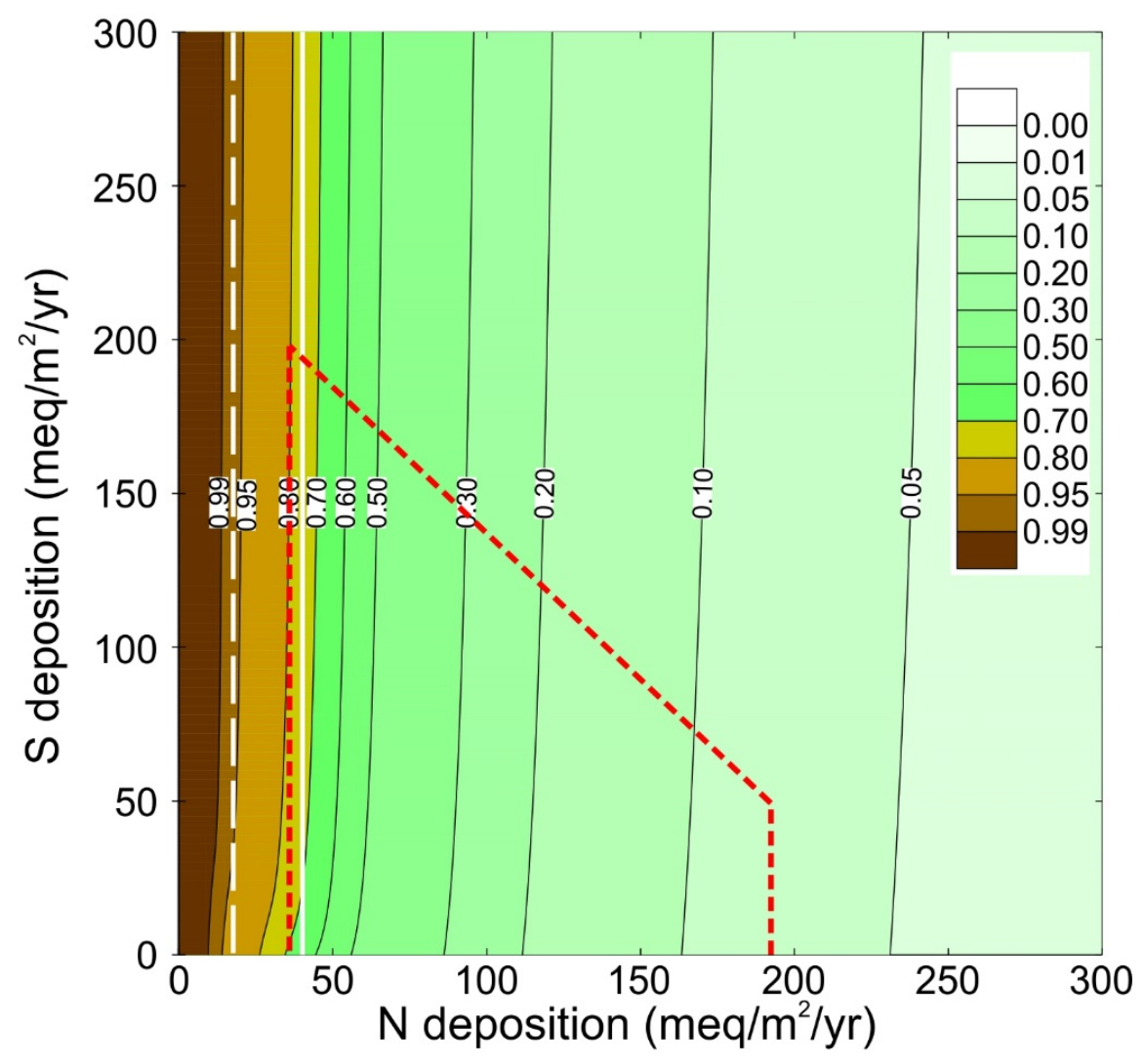

Figure 3. Critical load functions (CLFs) to attain occurrence probability of a) $75 \%$ (solid white line) and b) $95 \%$ (dashed white line) of the maximum occurrence probability for Trillium undulatum at Hubbard Brook (HB). The red dashed lines indicate the bounds of data used for developing the niche model for $T$. undulatum. 
Table 1. Number (and percent among all 1503 models) of species that included each predictor variable as a negative linear term only, positive linear term only, and quadratic term. Full models for each species are included in Supplemental Material 6.

\begin{tabular}{lcccc}
\hline Variable ID & $\begin{array}{c}\text { Negative Linear } \\
(\mathbf{\%})\end{array}$ & $\begin{array}{c}\text { Positive } \\
\text { Linear } \mathbf{( \% )}\end{array}$ & $\begin{array}{c}\text { Quadratic } \\
(\mathbf{\%})\end{array}$ & Total (\%) \\
\hline $\begin{array}{l}\text { Average annual } \\
\text { air temperature }\end{array}$ & $180(12)$ & $193(13)$ & $931(62)$ & $1304(87)$ \\
$\begin{array}{l}\text { Annual } \\
\text { precipitation } \\
\text { total }\end{array}$ & $262(17)$ & $133(9)$ & $757(50)$ & $1152(76)$ \\
$\begin{array}{l}\text { Average 30- } \\
\text { year annual N } \\
\text { deposition }\end{array}$ & $163(11)$ & $264(18)$ & $646(43)$ & $1073(72)$ \\
$\begin{array}{l}\text { Soil pH } \\
\text { Canopy cover }\end{array}$ & $297(20)$ & $315(21)$ & $417(28)$ & $1029(69)$ \\
$\begin{array}{l}\text { Incoming solar } \\
\text { radiation during }\end{array}$ & $245(16)$ & $203(14)$ & $450(30)$ & $898(60)$ \\
May - July. & $128(9)$ & & & \\
$\begin{array}{l}\text { Available water } \\
\text { storage }\end{array}$ & $258(17)$ & $367(24)$ & $245(16)$ & $870(57)$ \\
$\begin{array}{l}\text { Soil percent } \\
\text { clay }\end{array}$ & $157(10)$ & $329(22)$ & $373(25)$ & $859(57)$ \\
$\begin{array}{l}\text { Soil rooting } \\
\text { depth }\end{array}$ & $267(18)$ & $296(20)$ & $182(12)$ & $745(50)$ \\
\hline
\end{tabular}


Table 2. Estimated critical loads of $\mathrm{N}$ and $\mathrm{S}$ deposition to attain $95 \%$ of the maximum occurrence probability $(\mathrm{CL95})$ in units of meq/m $2 / \mathrm{yr}$ (and $\mathrm{kg} / \mathrm{ha} / \mathrm{yr}$ ) for individual indicator species at Hubbard Brook (HB), Piney River (PR), and Cosby Creek (CC). Highlighted grey cells indicate CL95 exceedance; "NA" indicates that the specified occurrence probability was not attainable at this site. Average annual ambient (2014 2016) $\mathrm{N}$ deposition for $\mathrm{HB}, \mathrm{PR}$, and CC was: $36 \mathrm{meq} / \mathrm{m}^{2} / \mathrm{yr}, 65 \mathrm{meq} / \mathrm{m}^{2} / \mathrm{yr}$, and $54 \mathrm{meq} / \mathrm{m}^{2} / \mathrm{yr}$, respectively. Average annual ambient (2014 2016) $S$ deposition for $\mathrm{HB}, \mathrm{PR}$, and $\mathrm{CC}$ was: $17 \mathrm{meq} / \mathrm{m}^{2} / \mathrm{yr}, 20 \mathrm{meq} / \mathrm{m}^{2} / \mathrm{yr}$, and $19 \mathrm{meq} / \mathrm{m}^{2} / \mathrm{yr}$, respectively.

\begin{tabular}{|c|c|c|c|c|c|c|c|c|}
\hline \multirow[b]{2}{*}{ Site } & \multirow[b]{2}{*}{$\begin{array}{l}\text { Species } \\
\text { Number }\end{array}$} & \multirow[b]{2}{*}{ Species Name } & \multicolumn{2}{|c|}{ Ambient Temp. } & \multicolumn{2}{|c|}{$+1.5^{\circ} \mathrm{C}$} & \multicolumn{2}{|c|}{$+3^{\circ} \mathrm{C}$} \\
\hline & & & $\begin{array}{c}\text { CL95 of N (at } \\
\text { Ambient S Dep) }\end{array}$ & $\begin{array}{c}\text { CL95 of S (at } \\
\text { Ambient N Dep) }\end{array}$ & $\begin{array}{c}\text { CL95 of N (at } \\
\text { Ambient S Dep) }\end{array}$ & $\begin{array}{c}\text { CL95 of S (at } \\
\text { Ambient N Dep) }\end{array}$ & $\begin{array}{c}\text { CL95 of N (at } \\
\text { Ambient S Dep) }\end{array}$ & $\begin{array}{c}\text { CL95 of S (at } \\
\text { Ambient N Dep) }\end{array}$ \\
\hline $\mathrm{HB}$ & 10020 & Acer pensylvanicum ${ }^{l}$ & $65(9.1)$ & $44(7)$ & $67(9.4)$ & $46(7.4)$ & $61(8.5)$ & $40(6.4)$ \\
\hline $\mathrm{HB}$ & 10024 & Acer saccharum & $51(7.1)$ & $7(1.1)$ & $48(6.7)$ & $1(0.2)$ & NA & NA \\
\hline $\mathrm{HB}$ & 10120 & Fagus grandifolia & $>300(>42)$ & $>300(>48)$ & $>300(>42)$ & $>300(>48)$ & $>300(>42)$ & $>300(>48)$ \\
\hline $\mathrm{HB}$ & 10125 & Fraxinus americana & $>300(>42)$ & $51(8.2)$ & $>300(>42)$ & $190(30.4)$ & $>300>(42)$ & $>300(>48)$ \\
\hline $\mathrm{HB}$ & 10201 & Picea rubens & $22(3.1)$ & $>300(>48)$ & $20(2.8)$ & $>300(>48)$ & $15(2.1)$ & $>300(>48)$ \\
\hline $\mathrm{HB}$ & 31274 & Dennstaedtia punctilobula & $>300(>42)$ & $88(14.1)$ & $>300(>42)$ & $148(23.7)$ & $>300(>42)$ & $105(16.8)$ \\
\hline HB & 31401 & Dryopteris intermedia & $26(3.6)$ & $>300(>48)$ & $21(2.9)$ & $>300(>48)$ & $17(2.4)$ & $>300(>48)$ \\
\hline $\mathrm{HB}$ & 32426 & Maianthemum racemosum & $39(5.5)$ & $4(0.6)$ & $39(5.5)$ & $8(1.3)$ & $39(5.5)$ & $10(1.6)$ \\
\hline $\mathrm{HB}$ & 32442 & Medeola virginiana ${ }^{l}$ & $62(8.7)$ & $41(6.6)$ & $64(9)$ & $43(6.9)$ & $65(9.1)$ & $44(7)$ \\
\hline $\mathrm{HB}$ & 32692 & Oxalis montana ${ }^{l}$ & $>300(>42)$ & $>300(>48)$ & $>300(>42)$ & $>300(>48)$ & $>300(>42)$ & $>300(>48)$ \\
\hline $\mathrm{HB}$ & 33750 & Trientalis borealis & $60(8.4)$ & $>300(>48)$ & $59(8.3)$ & $>300(>48)$ & $57(8)$ & $>300(>48)$ \\
\hline $\mathrm{HB}$ & 33786 & Trillium undulatum & $18(2.5)$ & $>300(>48)$ & $17(2.4)$ & $>300(>48)$ & $15(2.1)$ & $>300(>48)$ \\
\hline PR & 10020 & Acer pensylvanicum ${ }^{l}$ & $210(29.4)$ & $158(25.3)$ & $203(28.4)$ & $151(24.2)$ & $199(27.8)$ & $148(23.7)$ \\
\hline PR & 10070 & Carya ovata & $74(10.3)$ & $34(5.4)$ & $78(10.9)$ & $46(7.4)$ & $76(10.6)$ & $41(6.6)$ \\
\hline PR & 10125 & Fraxinus americana & $152(21.3)$ & $18(2.9)$ & $152(21.3)$ & $17(2.7)$ & $155(21.7)$ & $15(2.4)$ \\
\hline PR & 10241 & Prunus virginiana & $86(12)$ & $30(4.8)$ & $86(12)$ & $30(4.8)$ & $87(12.2)$ & $31(5)$ \\
\hline PR & 10248 & Quercus alba & $158(22.1)$ & $51(8.2)$ & $159(22.2)$ & $53(8.5)$ & $160(22.4)$ & $55(8.8)$ \\
\hline PR & 30035 & Actaea racemosa ${ }^{l}$ & $153(21.4)$ & $104(16.6)$ & $154(21.5)$ & $105(16.8)$ & $154(21.5)$ & $104(16.6)$ \\
\hline PR & 32010 & Hydrophyllum virginianum & $146(20.4)$ & $9(1.4)$ & $147(20.6)$ & $3(0.5)$ & NA & NA \\
\hline $\mathrm{CC}$ & 10020 & Acer pensylvanicum ${ }^{1}$ & $192(26.9)$ & $150(24)$ & $164(22.9)$ & $123(19.7)$ & $154(21.5)$ & $114(18.2)$ \\
\hline $\mathrm{CC}$ & 10024 & Acer saccharum & $61(8.5)$ & $27(4.3)$ & $59(8.3)$ & $22(3.5)$ & $57(8)$ & $19(3)$ \\
\hline $\mathrm{CC}$ & 10275 & Quercus rubra & $>300(>42)$ & $60(9.6)$ & $>300(>42)$ & $20(3.2)$ & NA & NA \\
\hline $\mathrm{CC}$ & 30052 & Ageratina altissima & $102(14.3)$ & $7(1.1)$ & $102(14.3)$ & $6(1)$ & $102(14.3)$ & $5(0.8)$ \\
\hline $\mathrm{CC}$ & 32142 & Laportea canadensis & $75(10.5)$ & $9(1.4)$ & NA & NA & NA & NA \\
\hline $\mathrm{CC}$ & 32426 & Maianthemum racemosum & $77(10.8)$ & $21(3.4)$ & $76(10.6)$ & $20(3.2)$ & $76(10.6)$ & $18(2.9)$ \\
\hline
\end{tabular}

${ }^{1}$ Critical loads for these species only represent acidifying effects from $\mathrm{N}$ and $\mathrm{S}$ 


\section{Declaration of interests}

૫ The authors declare that they have no known competing financial interests or personal relationships that could have appeared to influence the work reported in this paper.

$\square$ The authors declare the following financial interests/personal relationships which may be considered as potential competing interests:

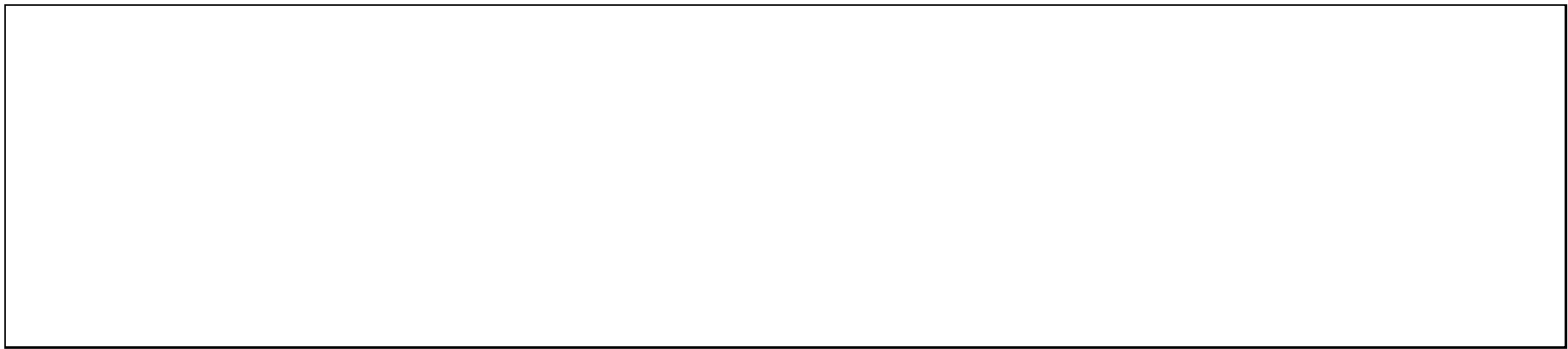




\section{$\underline{\text { Author Statement }}$}

T.C. McDonnell - Funding acquisition, Methodology, Formal analysis, Writing - Original Draft and Editing

G.J. Reinds - Methodology, Software, Formal analysis, Writing - Review and Editing

G.W.W. Wamelink - Methodology, Formal analysis, Writing - Review and Editing

P.W. Goedhart - Methodology, Software, Formal analysis, Writing - Review and Editing

M. Posch - Methodology, Software, Writing - Review and Editing

T.J. Sullivan - Supervision, Funding acquisition, Writing - Original Draft and Editing

C.M. Clark - Conceptualization, Project administration, Methodology, Writing - Review and Editing 
SUPPLEMENTAL MATERIAL 


\section{Supplemental Material 1.}

\begin{tabular}{|c|c|c|c|}
\hline Data Name & $\begin{array}{c}\text { Number of } \\
\text { Survey Plots }\end{array}$ & Location & Reference \\
\hline PNW & 6838 & Pacific Northwest of US & $\begin{array}{l}\text { Peet, R.K, Lee, M.T., Jennings, M.D., Faber-Langendoen, D. Long } \\
\text { database report: VegBank-A permanent, open-access archive for } \\
\text { vegetation-plot data. Pages } 233-241 \text { in Dengler, J. et al. } 2012 . \\
\text { Vegetation Databases for the } 21^{\text {st }} \text { Century. Biodiversity \& Ecology } 4 . \\
\text { Downloaded from VegBank. }\end{array}$ \\
\hline VA & 4513 & Southeastern US & $\begin{array}{l}\text { Provided by the Virginia Department of Conservation and Recreation, } \\
\text { Division of Natural Heritage, VA Plots, the DCR-DNH Vegetation } \\
\text { Plots Database. Data exported on March } 8,2013 \text {. Now available in } \\
\text { VegBank. }\end{array}$ \\
\hline MN_Releve & 4071 & Upper Midwest US & $\begin{array}{l}\text { Provided by Minnesota Biological Survey. Copyright } 2013 \text { State of } \\
\text { Minnesota, Department of Natural Resources. }\end{array}$ \\
\hline WV & 1921 & Southeastern US & $\begin{array}{l}\text { Vanderhorst, J.P., Byers, E.A., Streets, B.P. Short database report: } \\
\text { Natural Heritage Vegetation Database for West Virginia. Page } 440 \text { in } \\
\text { Dengler, J. et al. 2012. Vegetation Databases for the } 21^{\text {st }} \text { Century. } \\
\text { Biodiversity \& Ecology 4. Provided by the West Virginia Natural } \\
\text { Heritage Program. Now available in VegBank. }\end{array}$ \\
\hline FIA & 1919 & Contiguous US & $\begin{array}{l}\text { Schulz, B.K. and Dobelbower, K. Short database report: FIADB } \\
\text { vegetation diversity and structure indicator (VEG). Page } 436 \text { in } \\
\text { Dengler, J. et al. 2012. Vegetation Databases for the } 21^{\text {st }} \text { Century. } \\
\text { Biodiversity \& Ecology } 4 \text {. Provided by B. K. Schulz. Available from } \\
\text { apps.fs.fed.us/fiadb-downloads/datamart.html. }\end{array}$ \\
\hline Mojave_Thomas & 313 & Western US & $\begin{array}{l}\text { Thomas, K.A., T. Keeler-Wolf, J. Franklin, and P. Stine. } 2004 . \\
\text { Mojave Desert Ecosystem Program: Central Mojave vegetation } \\
\text { database. http://pubs.er.usgs.gov/publication/70200877 }\end{array}$ \\
\hline Knutson & 287 & Intermountain West of US & $\begin{array}{l}\text { Knutson, K.C., D.A. Pyke, T.A. Wirth, R.S. Arkle, D.S. Pilliod, M.L. } \\
\text { Brooks, J.C. Chambers, and J.B. Grace. 2014. Long-term effects of } \\
\text { seeding after wildfire on vegetation in Great Basin shrubland }\end{array}$ \\
\hline
\end{tabular}




\begin{tabular}{|c|c|c|c|}
\hline & & & $\begin{array}{l}\text { ecosystems. J. Appl. Ecol. 51(5):1414-1424 and } \\
\text { sagemap.wr.usgs.gov/ESR_Chrono.aspx }\end{array}$ \\
\hline NY_NHP & 250 & $\begin{array}{l}\text { Northeastern US (NY } \\
\text { Natural Heritage Program) }\end{array}$ & $\begin{array}{l}\text { Peet, R.K, Lee, M.T., Jennings, M.D., Faber-Langendoen, D. Long } \\
\text { database report: VegBank-A permanent, open-access archive for } \\
\text { vegetation-plot data. Pages } 233-241 \text { in Dengler, J. et al. } 2012 . \\
\text { Vegetation Databases for the } 21^{\text {st }} \text { Century. Biodiversity \& Ecology } 4 . \\
\text { Downloaded from VegBank. }\end{array}$ \\
\hline Cogbill & 183 & Northeastern US & Provided by Charles Cogbill (cogbill@sover.net) \\
\hline CA_Suding & 117 & Western US & Provided by Katharine Suding (suding@colorado.edu) \\
\hline SCPN & 102 & Western US & $\begin{array}{l}\text { DeCoster, J.K., C.L. Lauver, J.R. Norris, A.E.C. Snyder, M.C. Swan, } \\
\text { and L.P. Thomas. 2012. Integrated Upland Monitoring Protocol for } \\
\text { the Southern Colorado Plateau. Natural Resource Report } \\
\text { NPS/SCPN/NRR-2012/577. National Park Service, Fort Collins, CO. }\end{array}$ \\
\hline CO_Pawnee & 70 & $\begin{array}{l}\text { Western plains of US } \\
\text { (Pawnee Nat. Grassland) }\end{array}$ & $\begin{array}{l}\text { Peet RK, Lee MT, Jennings MD, Faber-Langendoen D. Long } \\
\text { Database Report: VegBank-A permanent, open-access archive for } \\
\text { vegetation-plot data. Pages } 233-241 \text { in Dengler, J. et al. } 2012 . \\
\text { Vegetation Databases for the } 21^{\text {st }} \text { Century. Biodiversity \& Ecology } 4 . \\
\text { Downloaded from VegBank. }\end{array}$ \\
\hline Mojave_Brooks & 64 & Western US & Provided by Matthew Brooks (mlbrooks@usgs.gov) \\
\hline WI_Waller & 60 & Upper Midwest US & $\begin{array}{l}\text { Waller, D.M., Amatangelo, K.L., Johnson, S., Rogers, D.A. Long } \\
\text { database report: Wisconsin Vegetation Database-Plant community } \\
\text { survey and resurvey data from the Wisconsin Plant Ecology } \\
\text { Laboratory. Pages } 255-264 \text { in Dengler, J. et al. 2012. Vegetation } \\
\text { Databases for the } 21^{\text {st }} \text { Century. Biodiversity \& Ecology 4. Provided by } \\
\text { D. M. Waller. }\end{array}$ \\
\hline Alvar & 39 & Northeastern US & $\begin{array}{l}\text { Peet, R.K, Lee, M.T., Jennings, M.D., Faber-Langendoen, D. Long } \\
\text { database report: VegBank-A permanent, open-access archive for } \\
\text { vegetation-plot data. Pages } 233-241 \text { in Dengler, J. et al. } 2012 . \\
\text { Vegetation Databases for the } 21^{\text {st }} \text { Century. Biodiversity \& Ecology } 4 . \\
\text { Downloaded from VegBank. }\end{array}$ \\
\hline AT & 30 & Eastern US & $\begin{array}{l}\text { Lawrence, G.B., T.J. Sullivan, D.A. Burns, S.A. Bailey, B.J. Cosby, } \\
\text { M. Dovciak, H.A. Ewing, T.C. McDonnell, R. Minocha, J. Quant, } \\
\text { K.C. Rice, J. Siemion, and K. Weathers. 2015. Acidic Deposition } \\
\text { along the Appalachian Trail Corridor and its Effects on Acid-Sensitive } \\
\text { Terrestrial and Aquatic Resources. Results of the Appalachian Trail }\end{array}$ \\
\hline
\end{tabular}




\begin{tabular}{|l|l|l|l|}
\hline & & & $\begin{array}{l}\text { MEGA-Transect Atmospheric Deposition Effects Study. Natural } \\
\text { Resource Report NPS/NRSS/ARD/NRR_2015/996. National Park } \\
\text { Service, Fort Collins, CO. }\end{array}$ \\
\hline PJ & 9 & Western US & $\begin{array}{l}\text { Pinyon juniper data collected by Samuel Simkin } \\
\text { (samuel.simkin@colorado.edu) and the William Bowman lab }\end{array}$ \\
\hline CA_Allen_JOTR & 7 & Western US & $\begin{array}{l}\text { DePrey, P. and E. B. Allen. 2011. Critical Levels of Nitrogen for } \\
\text { Growth, Litter Persistence, and Germination of } \\
\text { Invasive and Native Plants at Joshua Tree National Park. Final Report. }\end{array}$ \\
\hline CA_Bartolome & 7 & Western US & $\begin{array}{l}\text { Provided by Katharine Suding (suding@colorado.edu) and James } \\
\text { Bartolome }\end{array}$ \\
\hline CA_Allen_CSS & 6 & Western US & $\begin{array}{l}\text { California coastal sage scrub dataset collected by Edith Allen } \\
\text { (edith.allen@ucr.edu) }\end{array}$ \\
\hline
\end{tabular}




\section{Supplemental Material 2.}

\begin{tabular}{|c|c|c|c|c|c|c|}
\hline Type & Variable ID & $\begin{array}{l}\text { Variable } \\
\text { Name }\end{array}$ & Variable Description & Units & Resolution & Source \\
\hline \multirow[t]{2}{*}{ Climate } & PPTANN & $\begin{array}{l}\text { Annual } \\
\text { precipitation } \\
\text { total }\end{array}$ & $\begin{array}{l}\text { PRISM 30-year normal } \\
(1981 \text { - 2010) annual } \\
\text { precipitation total }\end{array}$ & $\mathrm{m}$ & $800 \mathrm{~m}$ & $\begin{array}{l}\text { http://www.prism.oregonstat } \\
\text { e.edu/normals/ }\end{array}$ \\
\hline & TANN & $\begin{array}{l}\text { Average } \\
\text { annual air } \\
\text { temperature }\end{array}$ & $\begin{array}{l}\text { PRISM 30-year normal } \\
(1981 \text { - 2010) average } \\
\text { annual temperature }\end{array}$ & degree $\mathrm{C}$ & $800 \mathrm{~m}$ & $\begin{array}{l}\text { http://www.prism.oregonstat } \\
\text { e.edu/normals/ }\end{array}$ \\
\hline Deposition & NDEP30 & $\begin{array}{l}\text { Average } 30- \\
\text { year annual } \mathrm{N} \\
\text { deposition }\end{array}$ & $\begin{array}{l}\text { Nitrogen }(\mathrm{N}) \text { supply } \\
\text { based on average total } \\
\mathrm{N} \text { deposition of } 30- \\
\text { years leading up to and } \\
\text { including the year of } \\
\text { vegetation sampling }\end{array}$ & $\mathrm{kg} / \mathrm{ha} / \mathrm{yr}$ & $\begin{array}{l}\sim 2 \mathrm{~km} \text { to } \\
\sim 4 \mathrm{~km}\end{array}$ & $\begin{array}{l}\text { Gronberg et al. (2014); } \\
\text { http://nadp.sws.uiuc.edu/ntn// } \\
\text { annualmapsByYear.aspx; } \\
\text { http://nadp.sws.uiuc.edu/co } \\
\text { mmittees/tdep/ }\end{array}$ \\
\hline \multirow[t]{4}{*}{$\begin{array}{l}\text { Soil } \\
\text { physio- } \\
\text { chemical }\end{array}$} & SOILPH & Soil pH & $\begin{array}{l}\text { Indicator of soil acidity } \\
\text { as reflected by } \mathrm{pH} \\
\text { measurements in } 1: 1 \\
\text { deionized water } \\
\text { represented in } \\
\text { SSURGO/STATSGO2 }\end{array}$ & $\mathrm{N} / \mathrm{A}$ & $30 \mathrm{~m}$ & $\begin{array}{l}\text { https://www.nrcs.usda.gov/w } \\
\text { ps/portal/nrcs/main/soils/sur } \\
\frac{\text { vey/ }}{\text { N. Bliss, personal }} \\
\text { communication, April } 2017\end{array}$ \\
\hline & SOILCLAY $^{1}$ & $\begin{array}{l}\text { Soil percent } \\
\text { clay }\end{array}$ & $\begin{array}{l}\text { Aspect of soil texture } \\
\text { and related to cation } \\
\text { exchange capacity } \\
\text { represented in } \\
\text { SSURGO/STATSGO2 }\end{array}$ & $\%$ & $30 \mathrm{~m}$ & $\begin{array}{l}\text { https://www.nrcs.usda.gov/w } \\
\text { ps/portal/nrcs/main/soils/sur } \\
\text { vey/ } \\
\text { N. Bliss, personal } \\
\text { communication, April } 2017\end{array}$ \\
\hline & $\mathrm{AWS}^{1}$ & $\begin{array}{l}\text { Available } \\
\text { water storage }\end{array}$ & $\begin{array}{l}\text { Available soil water } \\
\text { storage as a proxy for } \\
\text { soil moisture } \\
\text { represented in } \\
\text { SSURGO/STATSGO2 }\end{array}$ & $\mathrm{mm}$ & $30 \mathrm{~m}$ & $\begin{array}{l}\text { https://www.nrcs.usda.gov/w } \\
\text { ps/portal/nrcs/main/soils/sur } \\
\frac{\text { vey/ }}{\text { N. Bliss, personal }} \\
\text { communication, April } 2017\end{array}$ \\
\hline & $\begin{array}{l}\text { ROOTDEPT } \\
\mathrm{H}^{1}\end{array}$ & $\begin{array}{l}\text { Soil rooting } \\
\text { depth }\end{array}$ & $\begin{array}{l}\text { Depth of soil to } \\
\text { hardpan/bedrock or } \\
\text { chemically prohibitive } \\
\text { environment for root } \\
\text { growth represented in } \\
\text { SSURGO/STATSGO2 }\end{array}$ & $\mathrm{cm}$ & $30 \mathrm{~m}$ & $\begin{array}{l}\text { https://www.nrcs.usda.gov/w } \\
\text { ps/portal/nrcs/main/soils/sur } \\
\text { vey/ } \\
\text { N. Bliss, personal } \\
\text { communication, April } 2017\end{array}$ \\
\hline \multirow[t]{2}{*}{$\begin{array}{l}\text { Light } \\
\text { availability }\end{array}$} & $\mathrm{CC}^{1}$ & Canopy cover & $\begin{array}{l}\text { Percent forest canopy } \\
\text { cover. Data were } \\
\text { available for years } \\
2001,2008,2010 \text {, } \\
2012 \text {, and 2014. The } \\
\text { year nearest to the year } \\
\text { of vegetation survey } \\
\text { was used. }\end{array}$ & $\%$ & $30 \mathrm{~m}$ & $\begin{array}{l}\text { http://www.landfire.gov/veg } \\
\text { etation.php }\end{array}$ \\
\hline & SOLMJ & $\begin{array}{l}\text { Incoming } \\
\text { solar } \\
\text { radiation } \\
\text { during May - } \\
\text { July. }\end{array}$ & $\begin{array}{l}\text { Total incoming solar } \\
\text { radiation during the } \\
\text { months of May, June, } \\
\text { and July at } 200 \mathrm{~m} \\
\text { resolution. }\end{array}$ & $\mathrm{Wh} / \mathrm{m}^{2}$ & $200 \mathrm{~m}$ & Fu and Rich (2002) \\
\hline
\end{tabular}


Supplemental Material 3. Use of leverage scores to quantity extrapolation uncertainty.

The version of the US-PROPS model reported here included an uncertainty metric to describe unbounded extrapolation. Leverage scores were used to determine the extent to which the predictor variables associated with a given model application site were similar to the predictor variable data associated with the set of survey sites used to develop the response model for a given species. Leverage score considers not only the center of mass of the regressors in the calibration set, but also the shape of the distribution of these data (Cook and Weisberg 1982). The average leverage $\left(L_{a v}\right)$ associated with the dataset used to derive a response model for a given species equals $p / n$ where $p$ is the number of parameters in the regression model (including the constant) and $n$ is the number of sites in the calibration set. Leverage is also calculated for a given model application site $\left(L_{s i t e}\right)$. High ratios of $L_{s i t e} / L_{a v}$ indicate that the site has conditions that strongly deviate from the conditions (i.e., values for the predictor variables such as soil and climate variables) of the calibration dataset for a given species. Low ratios of $L_{s i t e} / L_{a v}($ e.g. $<2)$ indicate that conditions between the model application site and the calibration dataset are similar. The ratio of leverages can thus be used to determine if the derived species model is appropriate for application at a given location. Note that leverage is closely related to the Mahalanobis distance (Mahalanobis 1936), which is a multi-dimensional generalization of measuring how many standard deviations a point is from the mean of a distribution.

Prior to derivation of CLs for positive indicator species at the HB, PR and CC sites, leverage ratios were determined for each species to ensure that model application sites were characterized by abiotic conditions that are relevant for application of these species niche models. All leverage ratios were less than 2 (Table SM3-1), indicating that the niche models for this set of indicator species were suitable for application because the abiotic conditions at the 
model application sites were similar to the data used for niche model development for these species.

Table SM3-1. List of positive indicator species and the leverage ratio between data used for US-PROPS model development and site conditions at HB, PR, and $\mathrm{CC}$.

\begin{tabular}{|c|c|c|c|}
\hline Site & $\begin{array}{c}\text { Species } \\
\text { Number }\end{array}$ & Species & Leverage Ratio \\
\hline $\mathrm{HB}$ & 10020 & Acer pensylvanicum & 1.48 \\
\hline $\mathrm{HB}$ & 10024 & Acer saccharum & 1.49 \\
\hline $\mathrm{HB}$ & 10120 & Fagus grandifolia & 1.08 \\
\hline $\mathrm{HB}$ & 10125 & Fraxinus americana & 1.26 \\
\hline $\mathrm{HB}$ & 10201 & Picea rubens & 1.07 \\
\hline $\mathrm{HB}$ & 31274 & Dennstaedtia punctilobula & 1.24 \\
\hline $\mathrm{HB}$ & 31401 & Dryopteris intermedia & 1.50 \\
\hline $\mathrm{HB}$ & 32426 & Maianthemum racemosum & 0.66 \\
\hline $\mathrm{HB}$ & 32442 & Medeola virginiana & 1.50 \\
\hline $\mathrm{HB}$ & 32692 & Oxalis montana & 1.48 \\
\hline $\mathrm{HB}$ & 33750 & Trientalis borealis & 0.63 \\
\hline $\mathrm{HB}$ & 33786 & Trillium undulatum & 1.07 \\
\hline PR & 10020 & Acer pensylvanicum & 1.26 \\
\hline PR & 10070 & Carya ovata & 1.25 \\
\hline PR & 10125 & Fraxinus americana & 1.25 \\
\hline PR & 10241 & Prunus virginiana & 0.57 \\
\hline PR & 10248 & Quercus alba & 1.25 \\
\hline PR & 30035 & Actaea racemosa & 1.05 \\
\hline PR & 32010 & Hydrophyllum virginianum & 1.28 \\
\hline $\mathrm{CC}$ & 10020 & Acer pensylvanicum & 1.11 \\
\hline $\mathrm{CC}$ & 10024 & Acer saccharum & 1.11 \\
\hline $\mathrm{CC}$ & 10275 & Quercus rubra & 1.03 \\
\hline $\mathrm{CC}$ & 30052 & Ageratina altissima & 1.03 \\
\hline $\mathrm{CC}$ & 32142 & Laportea canadensis & 1.03 \\
\hline $\mathrm{CC}$ & 32426 & Maianthemum racemosum & 0.43 \\
\hline
\end{tabular}


Supplemental Material 4. Derivation of critical load functions (CLFs) using the PROPS-CLF model.

Application of the PROPS-CLF model requires input data related to site-specific soil and climatic conditions, net input of base cations to the soil, net soil $\mathrm{N}$ sinks, and denitrification (Table SM4-1; Posch 2017). By applying the combined SMB (Posch et al. 2015a) and USPROPS v2 model (within PROPS-CLF) various combinations of N and S deposition ( $\left.N_{d e p}, S_{d e p}\right)$ using a regular grid of $100 \times 100$ points, a computed probability of occurrence for a species (or set of species) can be obtained for each point. This computed probability is a function of the values for the predictor variables of the species niche models: seven of these are fixed for the site, but $\mathrm{pH}$ and $\mathrm{N}_{\mathrm{dep}}$ vary with deposition. To derive CLFs, the regular grid of computed occurrence probabilities needs to be expressed based on $N_{d e p}$ and $S_{d e p}$. Since $N_{d e p}$ is a predictor variable in US-PROPS (v2), no conversions are needed. To obtain the link between soil $\mathrm{pH}$ and $S_{d e p}$, we note that $N_{d e p}$ also influences soil $\mathrm{pH}$. Thus, we first compute the soil solution N concentration, $[\mathrm{N}]$, from Ndep via the steady-state mass balance for $\mathrm{N}$, i.e.

(A) $[N]=\left(N_{d e p}-N_{i}-N_{u}\right)\left(1-f_{d e}\right) / Q$ where $N_{i}$ and $N_{u}$ are the long-term average immobilization and net uptake (removal) of N, $f_{d e}$ is the denitrification fraction, and $Q$ is the runoff (percolation flux). The corresponding $S_{d e p}$, is then obtained by using $[\mathrm{H}+]$ (from $\mathrm{pH}$ ) to compute the ANC leaching, $A N C_{l e}$, and from the charge balance we obtain:

$$
S_{d e p}=B C_{l e}-C l_{l e}-A N C_{l e}-Q[N]
$$


where the subscript le denotes the leaching of base cations $(\mathrm{BC})$, chloride $(\mathrm{Cl})$ and $\mathrm{ANC}$, with $[A N C]=A N C_{l e} / Q$ defined as $-[H]-[A l]+[H C O 3]+[\mathrm{Org}]$; for more details, see Chapter 6 of De Vries et al. (2015) and (Posch et al. 2014).

Using the regular grid of computed probabilities, isolines of equal Habitat Suitability Index (HSI) can be constructed in the two-dimensional $\mathrm{N}_{\text {dep }}-\mathrm{S}_{\text {dep }}$ plane (Figure SM4-1). The HSI is computed as the average relative probability occurrence over all considered species, where the relative probability occurrence is computed by dividing the computed probability occurrence by the maximum probability occurrence of the species at the site:

$$
H S I=\frac{1}{n} \sum_{k=1}^{n} \frac{\operatorname{prob}_{k}}{\operatorname{prob}_{k, \max }}
$$

where $n$ is the total number of indicator species, $\operatorname{rrob}_{k}$ is the occurrence probability of species $k$, and $\operatorname{prob}_{k, \text { max }}$ is the maximum occurrence probability of species $k$.

Two approaches for determining the CLF from isolines of occurrence probability can be used:

1. Compute the HSI-isoline defined by the desired occurrence probability and determine the point with the highest N-dep value (P1 in Figure SM4-1) and the highest S-dep value (P2); and these two points define a CLF (Posch et al. 2014, Posch 2017).

2. Determine the location of the maximum HSI (point M in Figure SM4-1) and go 'eastwards' until reaching the value of the desired probability (point Q1) and 'northwards' till reaching Q2; and these two points define a CLF (Posch et al. 2015b, Posch 2017). 


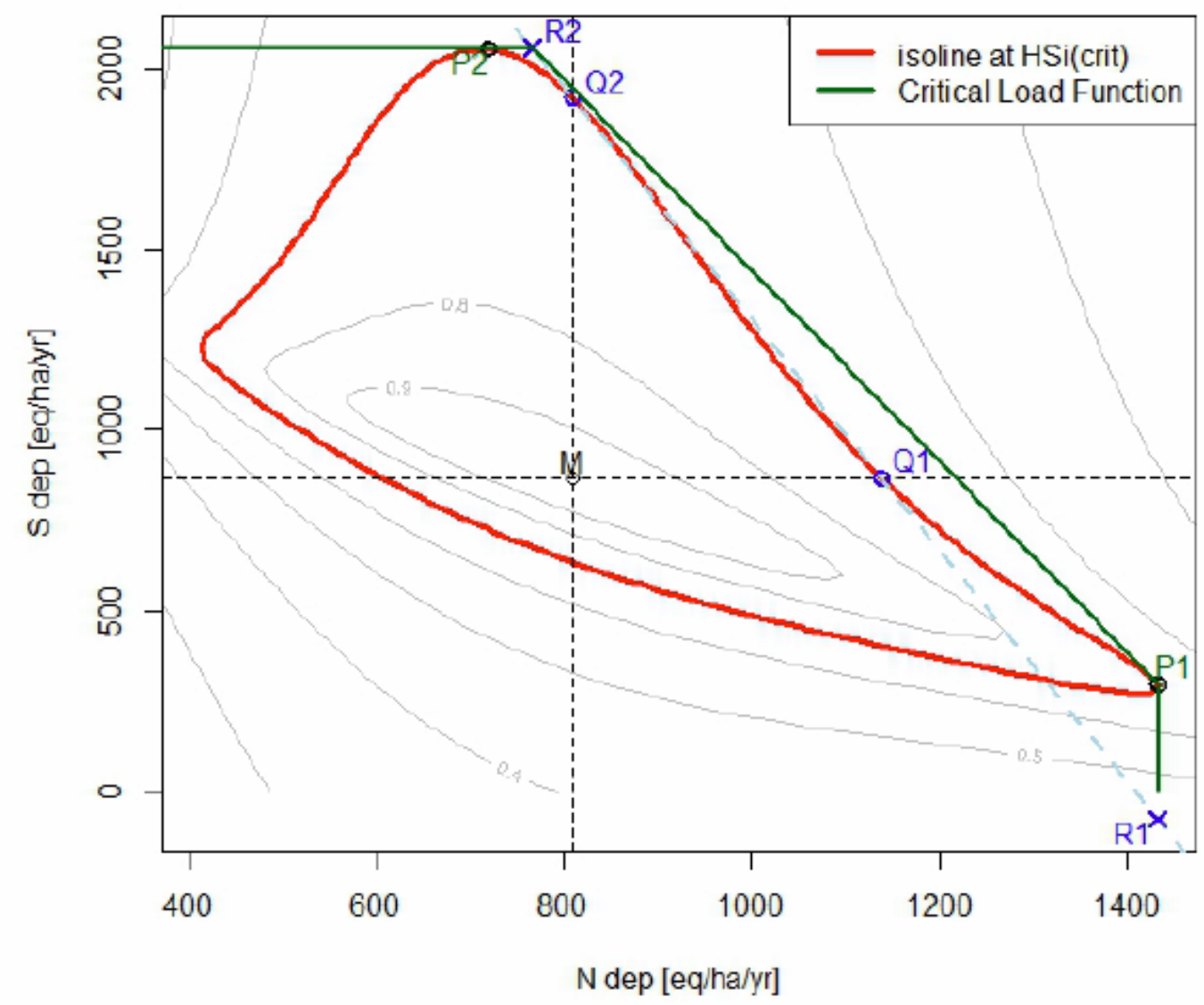

Figure SM4-1. Depiction of steps involved with derivation of the critical load function (CLF) with PROPS-CLF (see text for further description; adapted from Posch 2017).

PROPS-CLF combines both methods to compute the CLs because, depending on the shape of the curve, one method may be more appropriate than the other. PROPS-CLF computes the CLF by combining the two approaches, described as:

1. the N-dep value of $\mathrm{P} 1$ and the S-dep value of $\mathrm{P} 2$ define $\mathrm{CLN}_{\max }$ and $C L \mathrm{~S}_{\max }$, respectively;

2. intersect the straight line defined by Q1 and Q2 (diagonal dashed line in Figure SM41) with the values from step 1 to generate the points $R 1$ and $R 2$;

3. $\mathrm{CLN}_{\min }$ is the greater of the $\mathrm{N}$-dep values at $\mathrm{P} 2$ and $\mathrm{R} 2$, and $\mathrm{CLS}_{\min }$ the greater of the $\mathrm{S}$-dep values at $\mathrm{P} 1$ and $\mathrm{R} 1$. 
Thus, the CLF is defined by the points R2 and P1 in the example shown in Figure SM41. $\mathrm{CLN}_{\max }$ and $\mathrm{CLS}_{\max }$ represent the maximum amount of $\mathrm{N}$ and $\mathrm{S}$ deposition, respectively, that is expected to attain the specified level of occurrence probability. CLN $\mathrm{N}_{\min }$ and CLS $_{\min }$ define the minimum amount of $\mathrm{N}$ and $\mathrm{S}$ deposition, respectively, needed to attain the specified occurrence probability (Supplemental Material 5).

\begin{tabular}{|c|c|c|c|c|}
\hline $\begin{array}{l}\text { Site } \\
\text { Characteristic }\end{array}$ & $\begin{array}{l}\text { Hubbard } \\
\text { Brook } \\
\text { (HB) }\end{array}$ & $\begin{array}{l}\text { Piney } \\
\text { River } \\
\text { (PR) }\end{array}$ & $\begin{array}{l}\text { Cosby } \\
\text { Creek } \\
\text { (CC) }\end{array}$ & Source \\
\hline $\begin{array}{l}\text { Soil rooting depth } \\
(\mathrm{cm})\end{array}$ & 124.0 & 117.0 & 38.0 & $\begin{array}{l}\text { https://www.nrcs.usda.gov/wps/portal/nrcs/main/soils } \\
\text { survey/ } \\
\text { N. Bliss, personal communication, April } 2017\end{array}$ \\
\hline $\begin{array}{l}\text { Available water } \\
\text { storage }(\mathrm{mm})\end{array}$ & 128.0 & 96.8 & 58.6 & $\begin{array}{l}\frac{\text { https://www.nrcs.usda.gov/wps/portal/nrcs/main/soils }}{\text { /survey/ }} \\
\text { N. Bliss, personal communication, April } 2017\end{array}$ \\
\hline $\begin{array}{l}\text { Soil percent clay } \\
(\%)\end{array}$ & 5 & 25 & 14 & $\begin{array}{l}\text { https://www.nrcs.usda.gov/wps/portal/nrcs/main/soils } \\
\text { survey/ } \\
\text { N. Bliss, personal communication, April } 2017\end{array}$ \\
\hline $\begin{array}{l}\text { Annual } \\
\text { precipitation total } \\
(\mathrm{mm})\end{array}$ & 1358.1 & 1410.5 & 1683.6 & http://www.prism.oregonstate.edu/normals/ \\
\hline $\begin{array}{l}\text { Average annual air } \\
\text { temperature (deg } \\
\text { C) }\end{array}$ & 5.0 & 9.4 & 10.7 & http://www.prism.oregonstate.edu/normals/ \\
\hline $\begin{array}{l}\text { Incoming solar } \\
\text { radiation during } \\
\text { May - July } \\
\left(\mathrm{MWh} / \mathrm{m}^{2}\right)\end{array}$ & 0.5 & 0.7 & 0.5 & Fu and Rich (2002) \\
\hline Canopy cover $(\%)$ & 85.0 & 85.0 & 85.0 & http://www.landfire.gov/vegetation.php \\
\hline Runoff (m) & 0.649 & 0.679 & 0.984 & McDonnell et al. (2018) \\
\hline $\begin{array}{l}\text { Net input of base } \\
\text { cations }\left(\mathrm{eq} / \mathrm{m}^{2}\right)\end{array}$ & 0.0392 & 0.1843 & 0.1068 & McDonnell et al. (2018) \\
\hline $\begin{array}{l}\text { Net sink of } \\
\text { nitrogen }\left(\mathrm{eq} / \mathrm{m}^{2}\right)\end{array}$ & 0 & 0 & 0 & $\begin{array}{l}\text { https://www.umweltbundesamt.de/en/manual-for- } \\
\text { modelling-mapping-critical-loads-levels }\end{array}$ \\
\hline $\begin{array}{l}\text { Denitrification } \\
\text { fraction }\end{array}$ & 0.05 & 0.05 & 0.05 & $\begin{array}{l}\text { https://www.umweltbundesamt.de/en/manual-for- } \\
\text { modelling-mapping-critical-loads-levels }\end{array}$ \\
\hline
\end{tabular}


Supplemental Material 5. Derivation of conditional critical loads of $\mathrm{N}$ and $\mathrm{S}$ based on critical load functions.

The non-uniqueness of the critical loads of $\mathrm{S}$ and $\mathrm{N}$, makes their communication to decision makers more difficult. However, if one is interested in reductions of only one of the two pollutants, a unique critical load can be derived (see Chapter 3 in Posch et al. 1995, for the original derivation) from a critical load function (CLF, see Figure SM5-1) defined by the quantities $C L N_{\max }, C L S_{\max }, C L N_{\min }$, and $C L S_{\min }$.

If emission reductions deal with nitrogen only, a unique critical load of $\mathrm{N}$ for a fixed sulphur deposition $S_{d e p}$ can be derived from the critical load function. Calling it the conditional critical load of nitrogen, $C L\left(N \mid S_{d e p}\right)$, it is computed as:

$$
C L\left(N \mid S_{\text {dep }}\right)=\left\{\begin{array}{cc}
C L N_{\text {max }} & \text { if } S_{\text {dep }} \leq C L S_{\text {min }} \\
C L N_{\text {min }}+\left(C L S_{\text {max }}-S_{d e p}\right) / \alpha & \text { if } C L S_{\text {min }}<S_{\text {dep }}<C L S_{\text {max }} \\
C L N_{\text {min }} & \text { if } S_{\text {dep }} \geq C L S_{\text {max }}
\end{array}\right.
$$

with the slope

$$
\alpha=\frac{C L S_{\max }-C L S_{\min }}{C L N_{\max }-C L N_{\min }}
$$

In Figure SM5-1a the calculation of $C L\left(N \mid S_{d e p}\right)$ is depicted graphically.
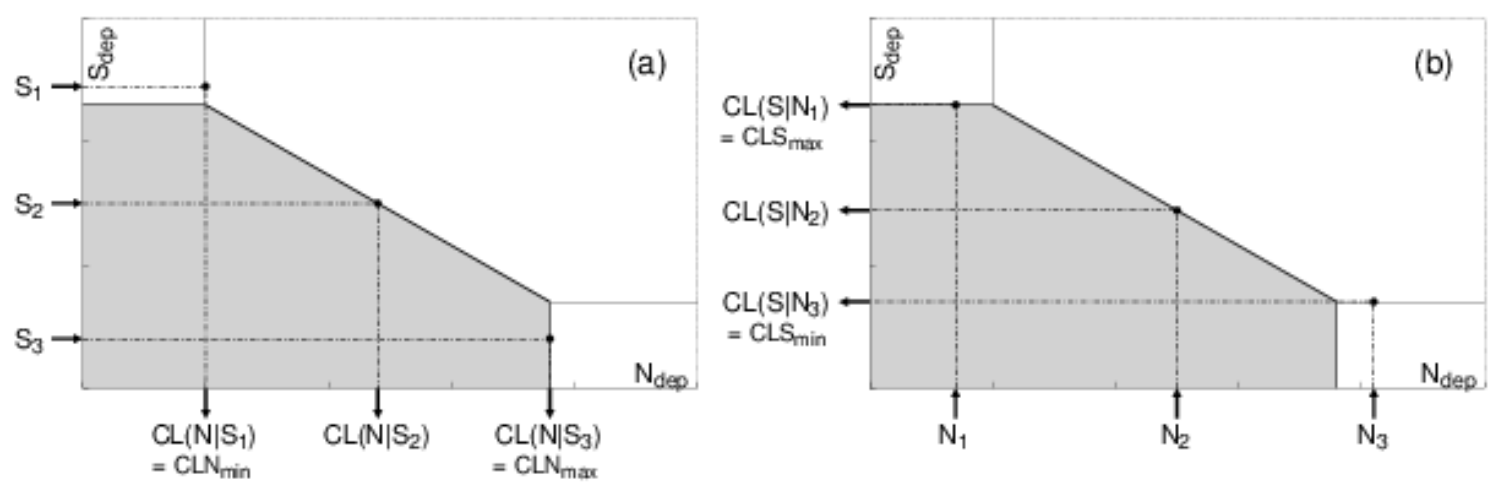

Figure SM5-1. Examples of computing (a) conditional critical loads of $\mathbf{N}$ for different $\mathbf{S}$ deposition values $\mathbf{S}_{\mathbf{1}^{-}}$ $S_{3}$, and (b) conditional critical loads of $S$ for different $N$ deposition values $N_{1}-N_{3}$, from a given critical load function defined by $C L N_{\max }, C L S_{\max }, C L N_{\min }$, and $C L S_{\min }$.

In an analogous manner a conditional critical load of sulphur, $C L\left(S \mid N_{d e p}\right)$, for a fixed nitrogen deposition $N_{\text {dep }}$ is computed as: 
$C L\left(S \mid N_{\text {dep }}\right)=\left\{\begin{array}{cc}C L S_{\max } & \text { if } N_{\text {dep }} \leq C L N_{\min } \\ C L S_{\max }-\alpha\left(N_{\text {dep }}-C L N_{\min }\right) & \text { if } C L N_{\min }<N_{\text {dep }}<C L N_{\max } \\ C L S_{\min } & \text { if } N_{\text {dep }} \geq C L N_{\max }\end{array}\right.$

where $\alpha$ is given by eq.SM5-2; and in Figure SM5-1b the calculation of $C L\left(S \mid N_{d e p}\right)$ is depicted graphically.

When using conditional critical loads, the following caveats should be kept in mind:

(a) A conditional critical load can be considered a true critical load only when the chosen deposition of the other pollutant is kept constant.

(b) If $S_{\text {dep }}>C L S_{\max }$ or $N_{\text {dep }}>C L N_{\max }$, depositions have to be reduced at least to their respective maximum critical load values to achieve overall non-exceedance.

(c) If the conditional critical loads of both pollutants are considered simultaneously, care has to be exercised. It is not necessary to reduce the exceedances of both, but only one of them to reach non-exceedance for both pollutants; recalculating the conditional critical load of the other pollutant results (in general) in non-exceedance. 
Supplemental Material 7. Visualization of US-PROPS model application results at the vegetation survey sites used for model development (red lines) and observed probability of occurrence among intervals of abiotic predictor variables at the same sites (blue lines) for the selected indicator species. 

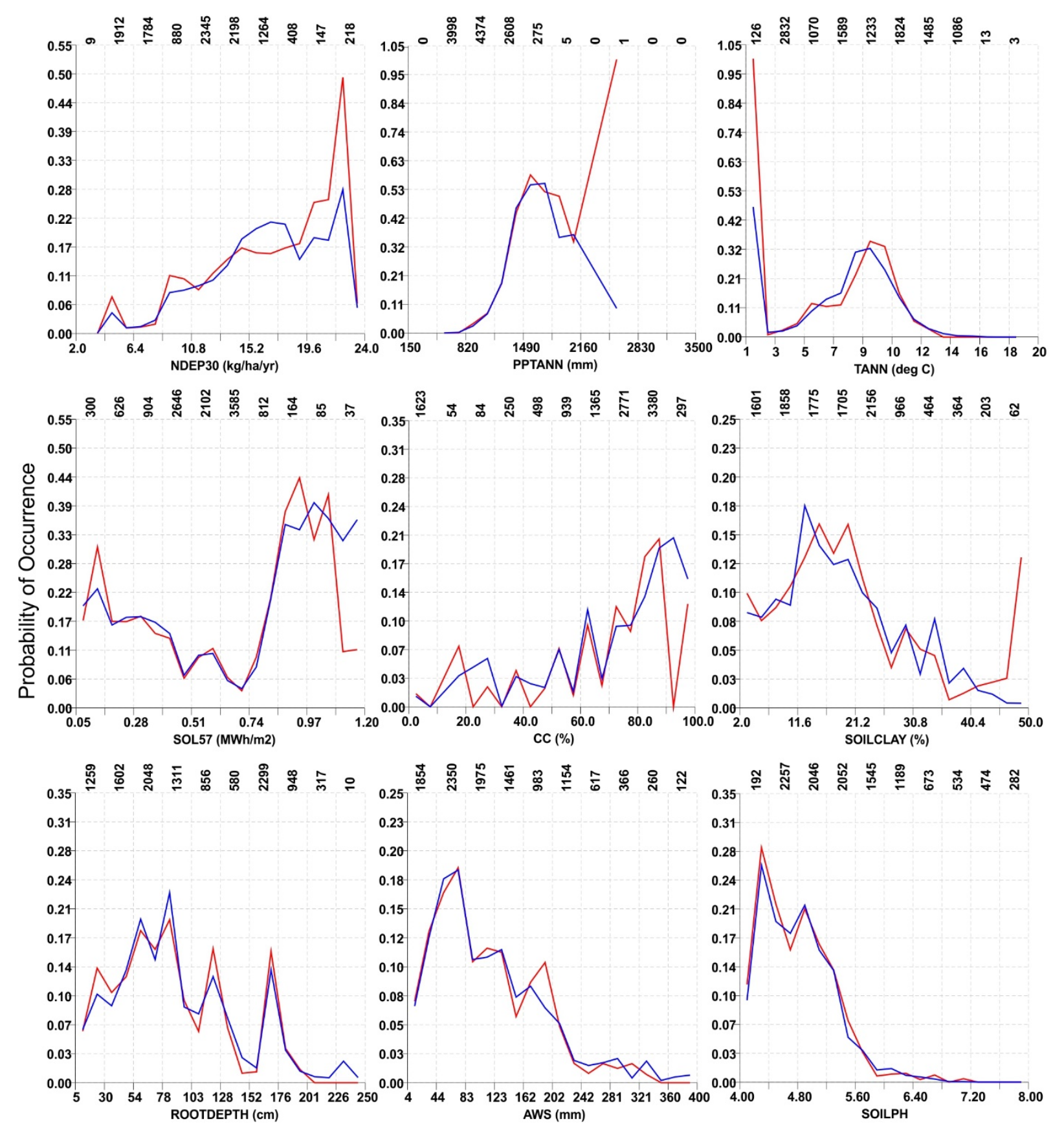

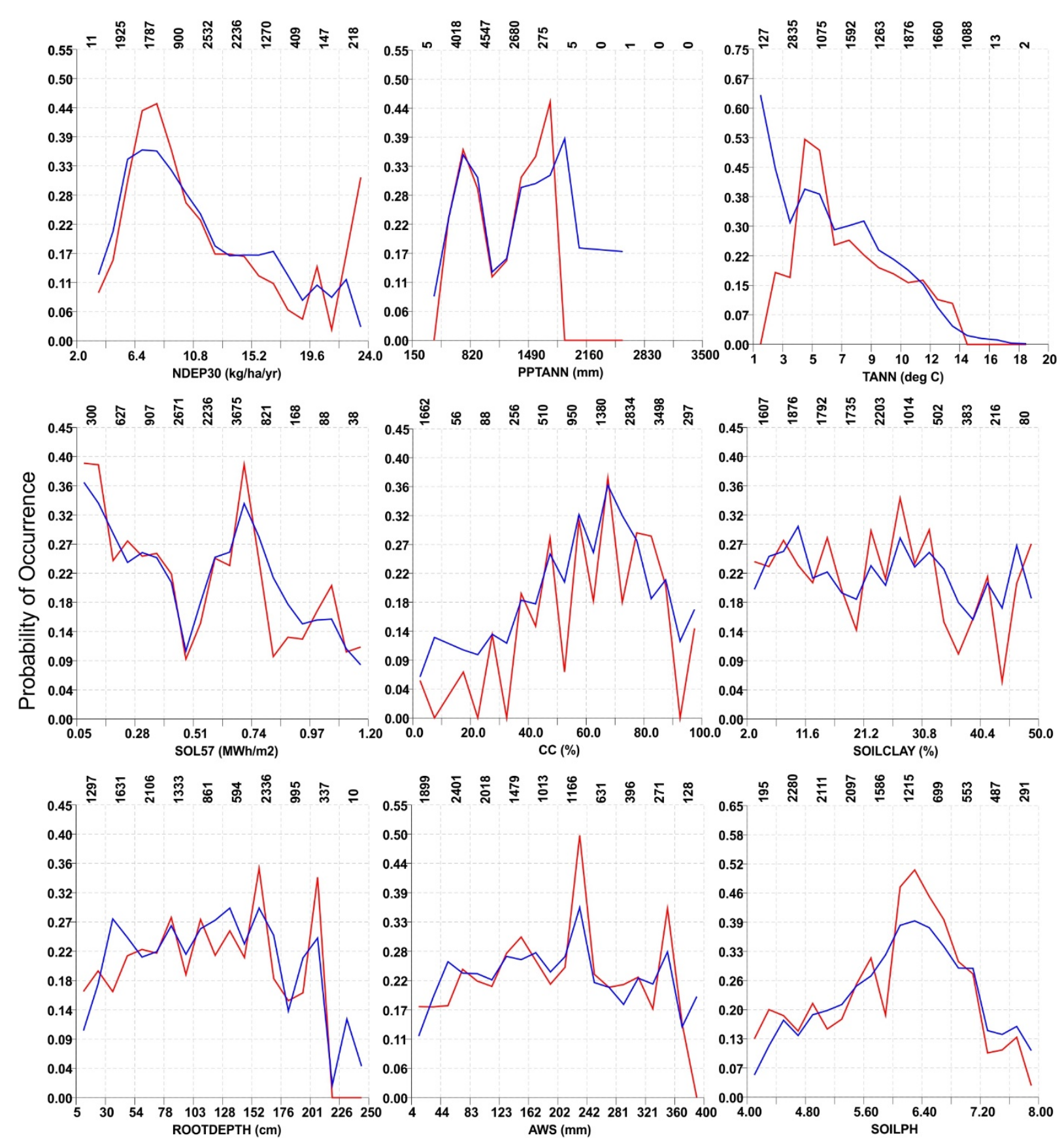

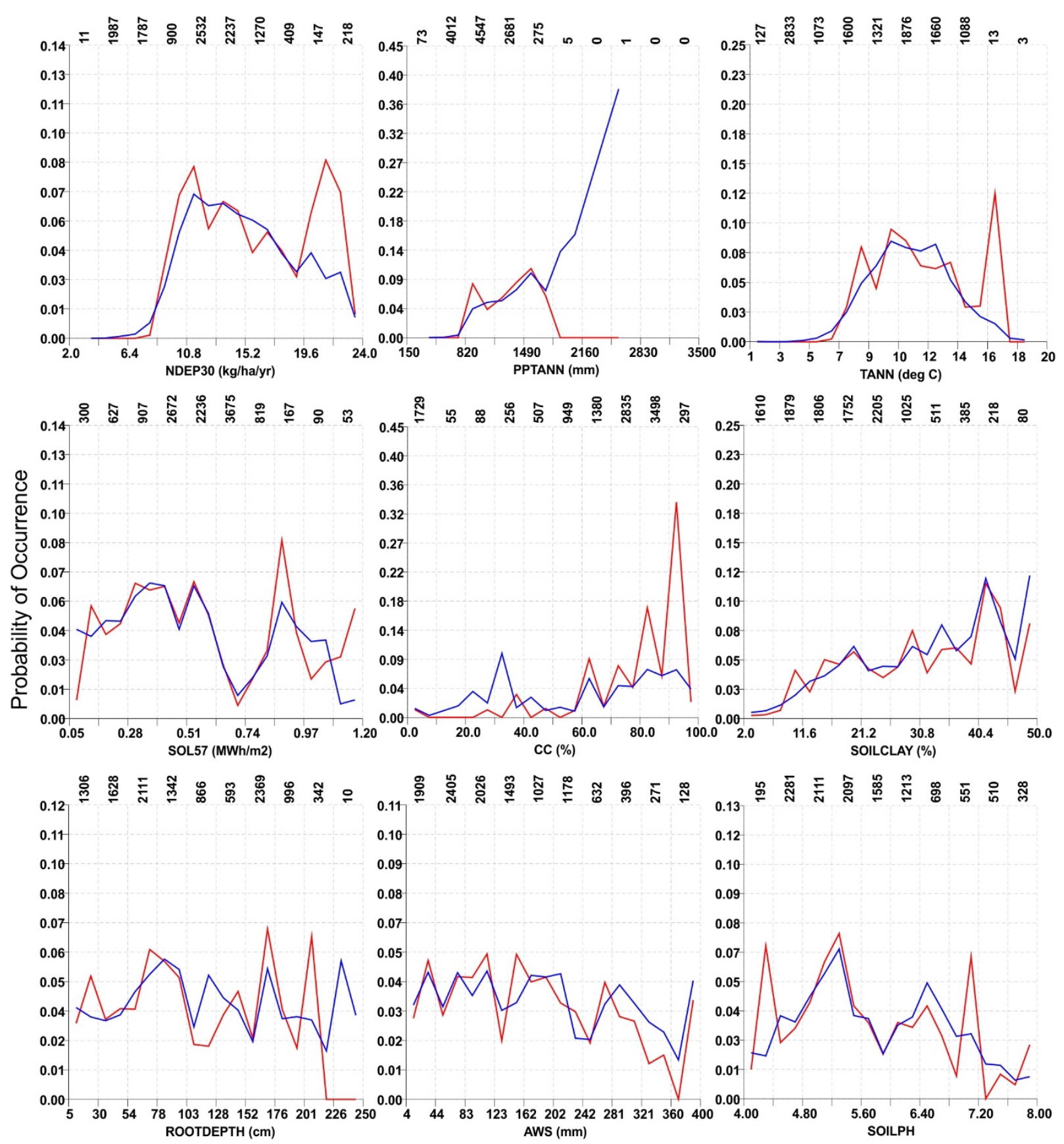


\section{0 (Fagus grandifolia)}

- Observed - Modelled
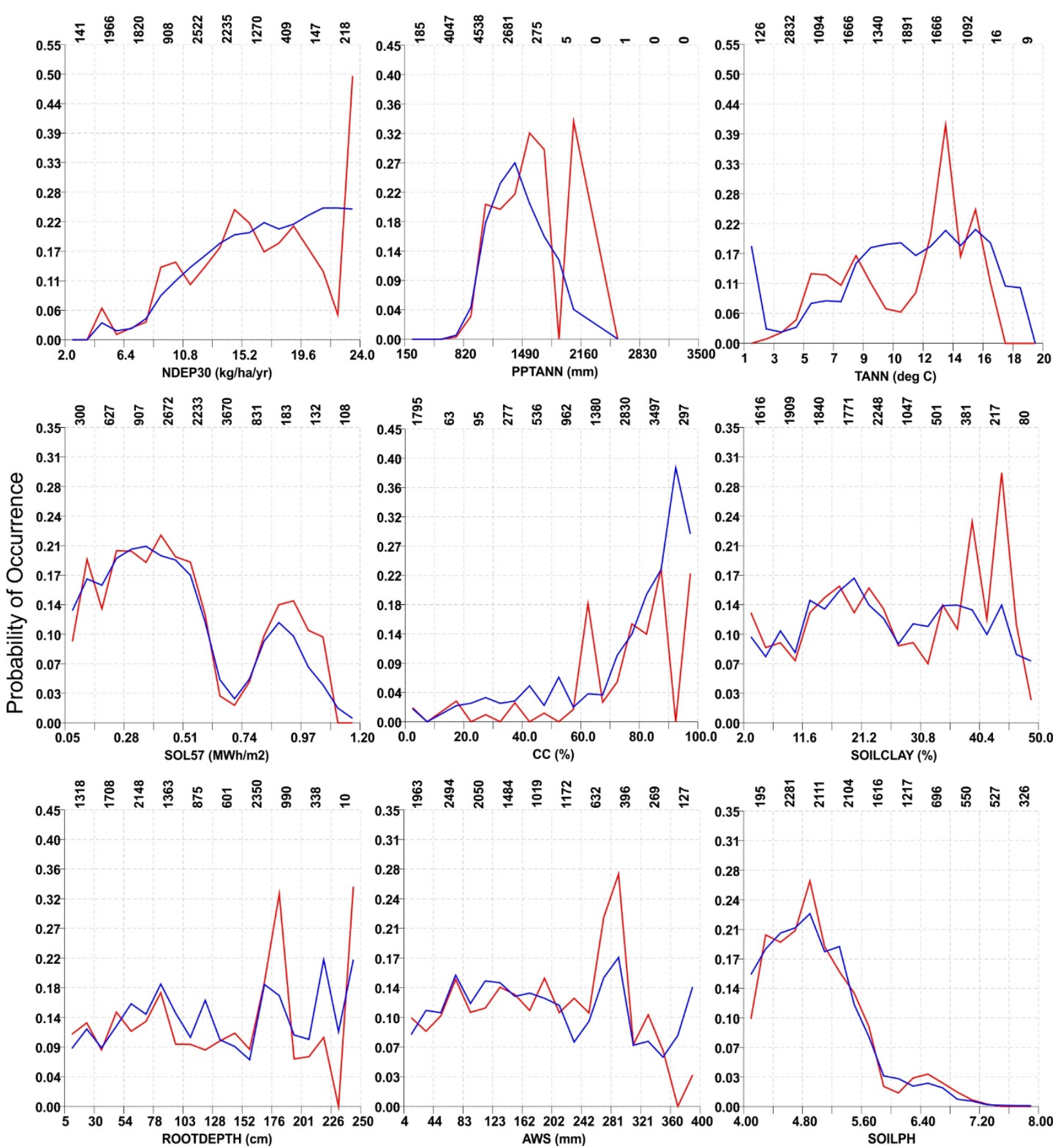

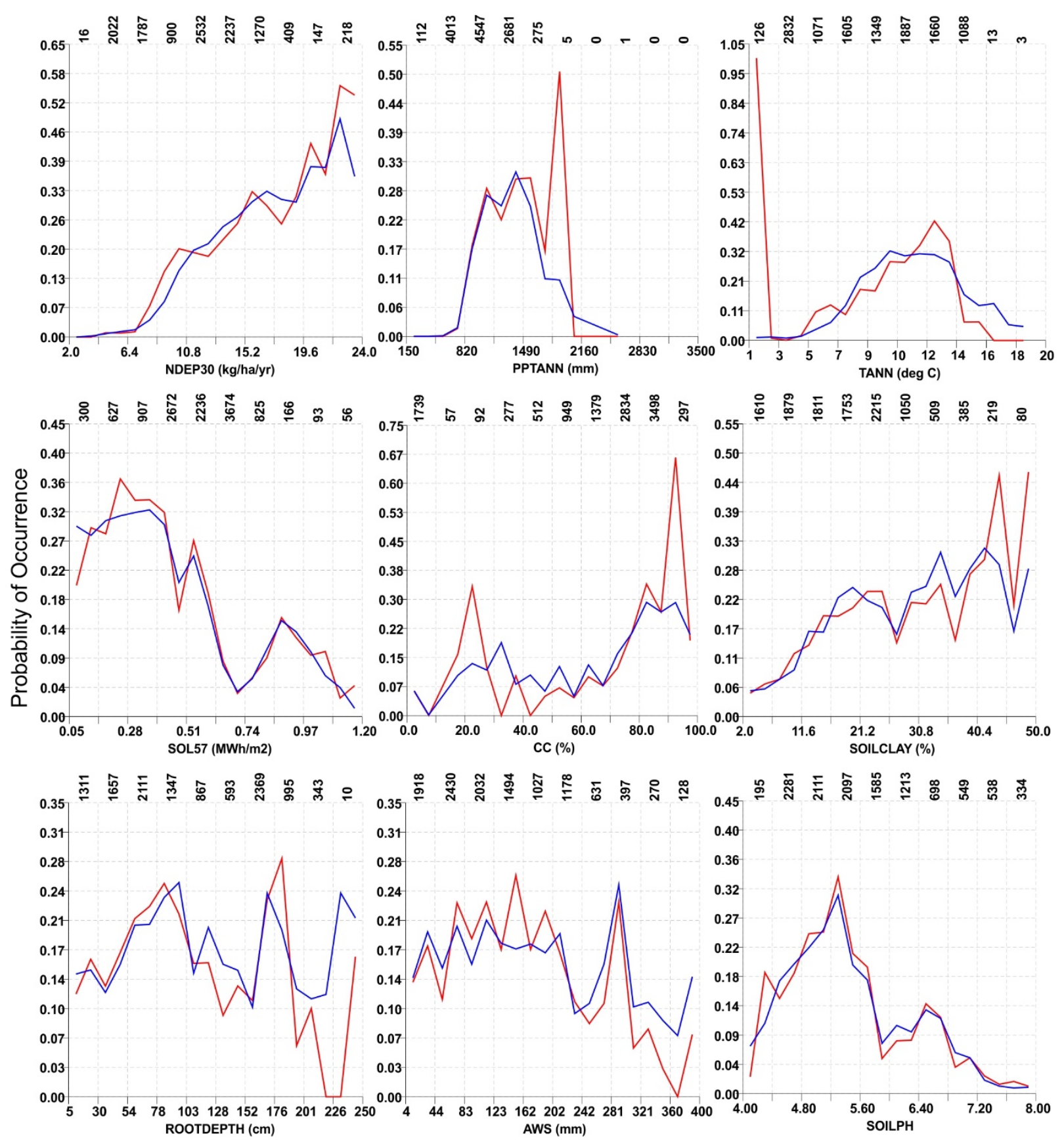


\section{1 (Picea rubens)}

\section{- Observed $\quad$ Modelled}
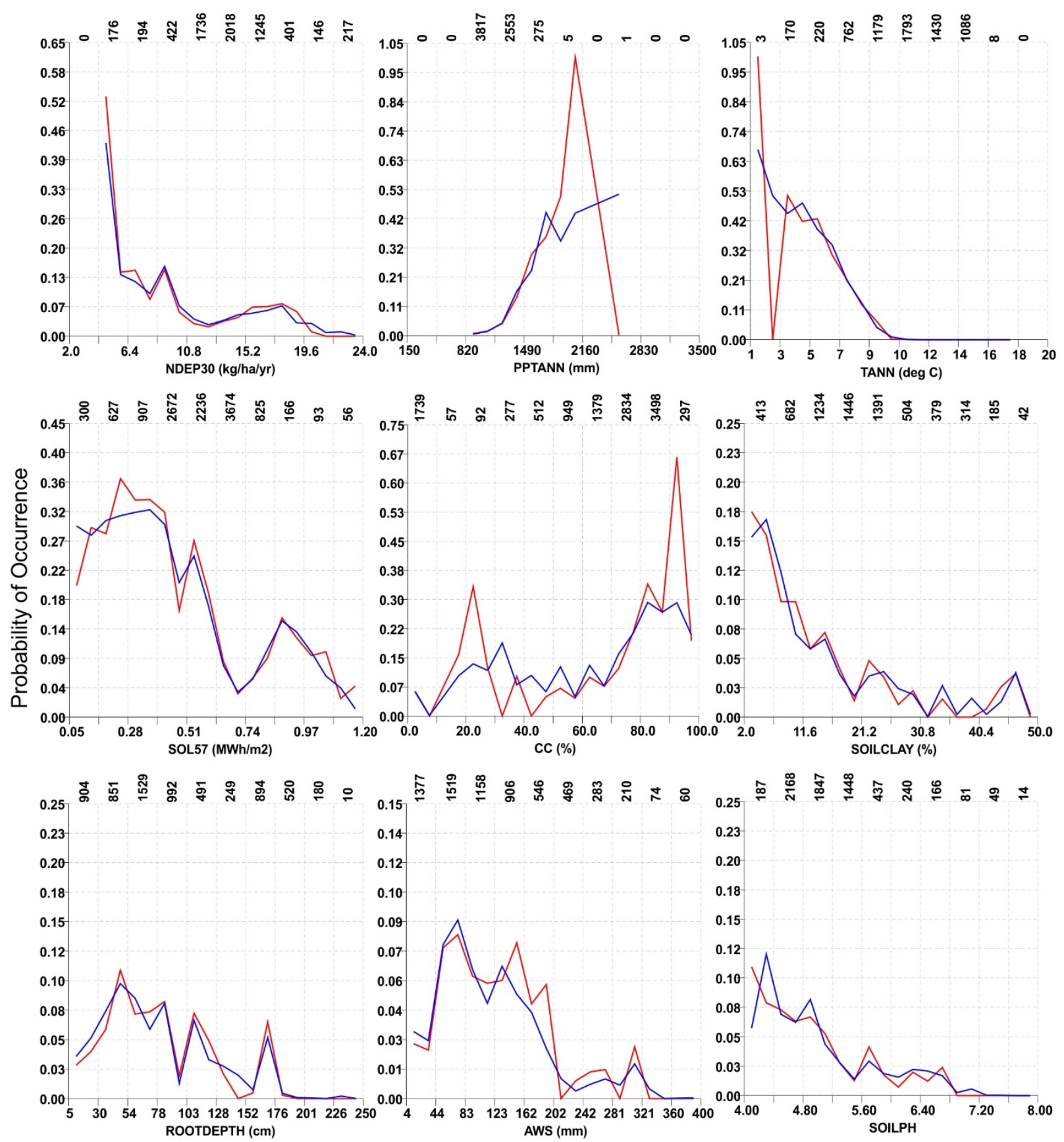

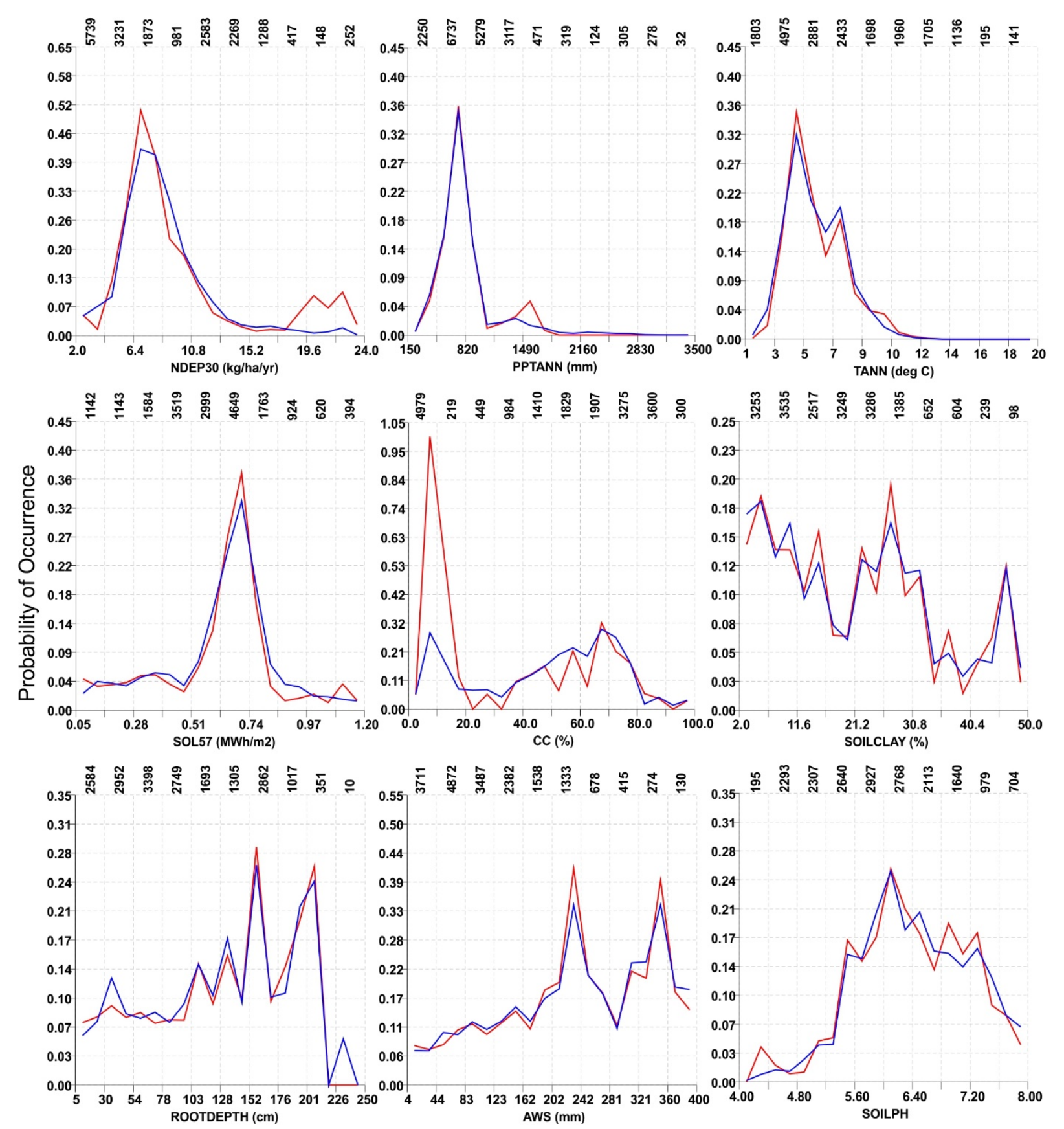

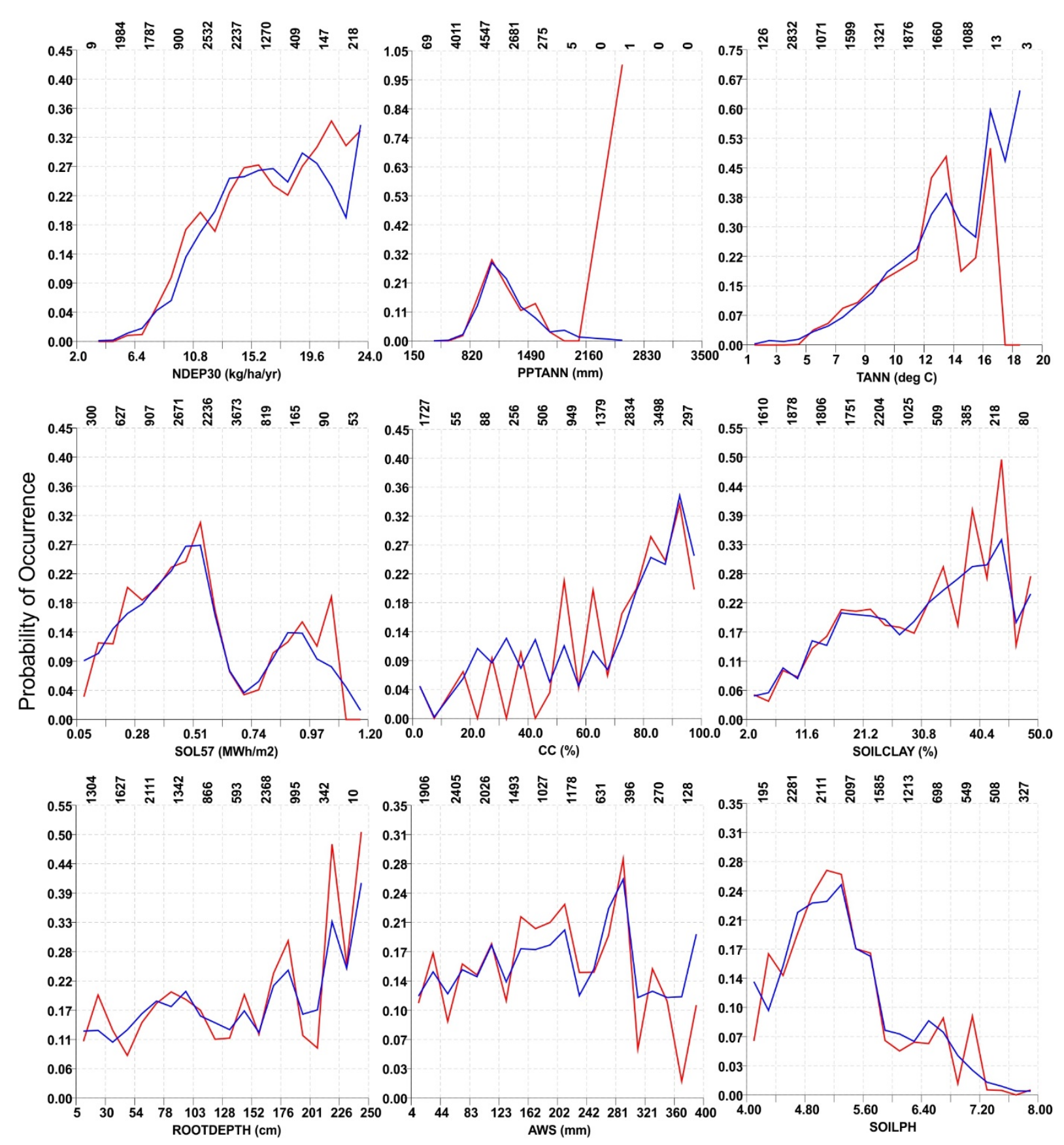

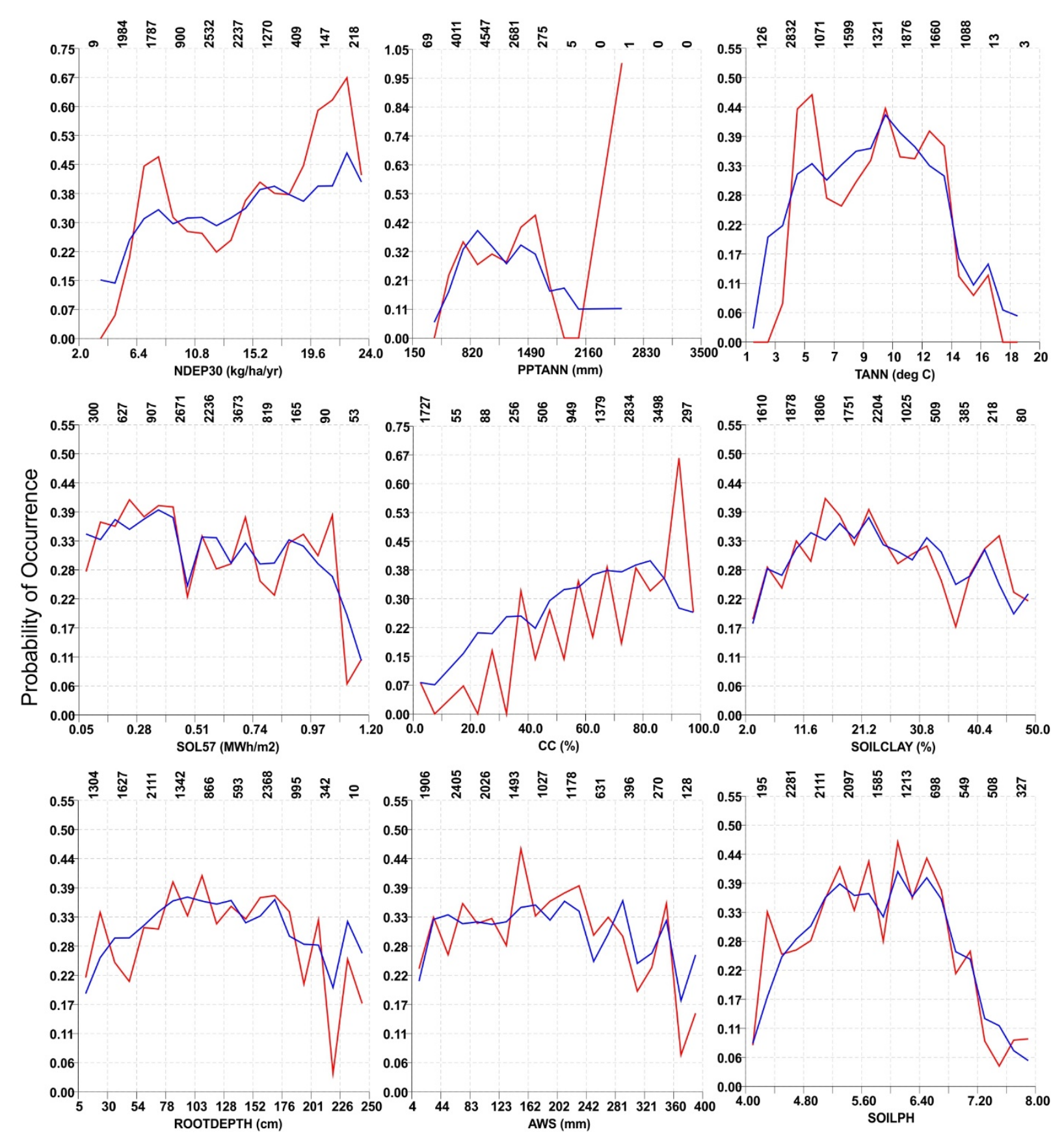

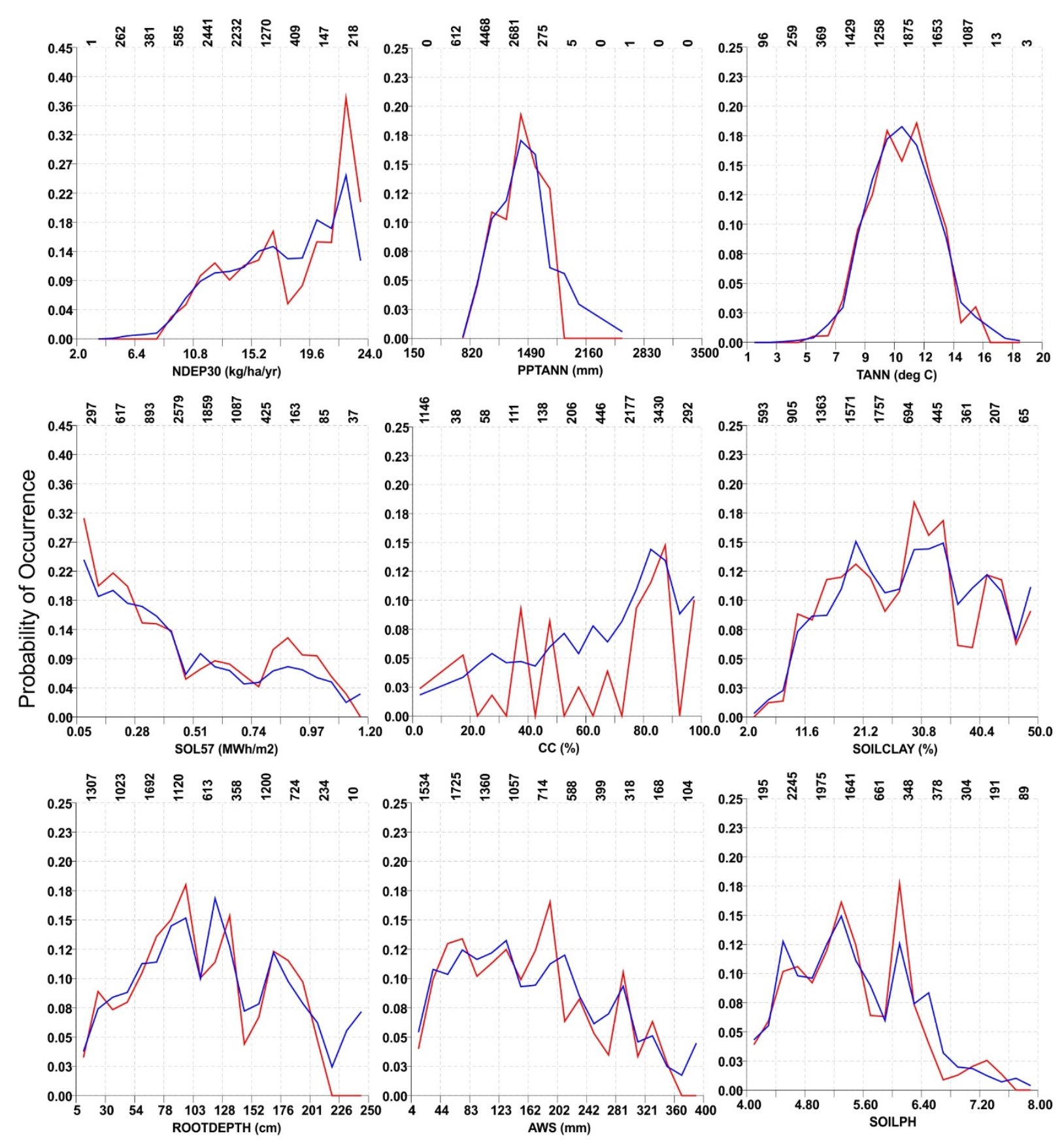


\section{2 (Ageratina altissima)}

- Observed $\quad$ Modelled
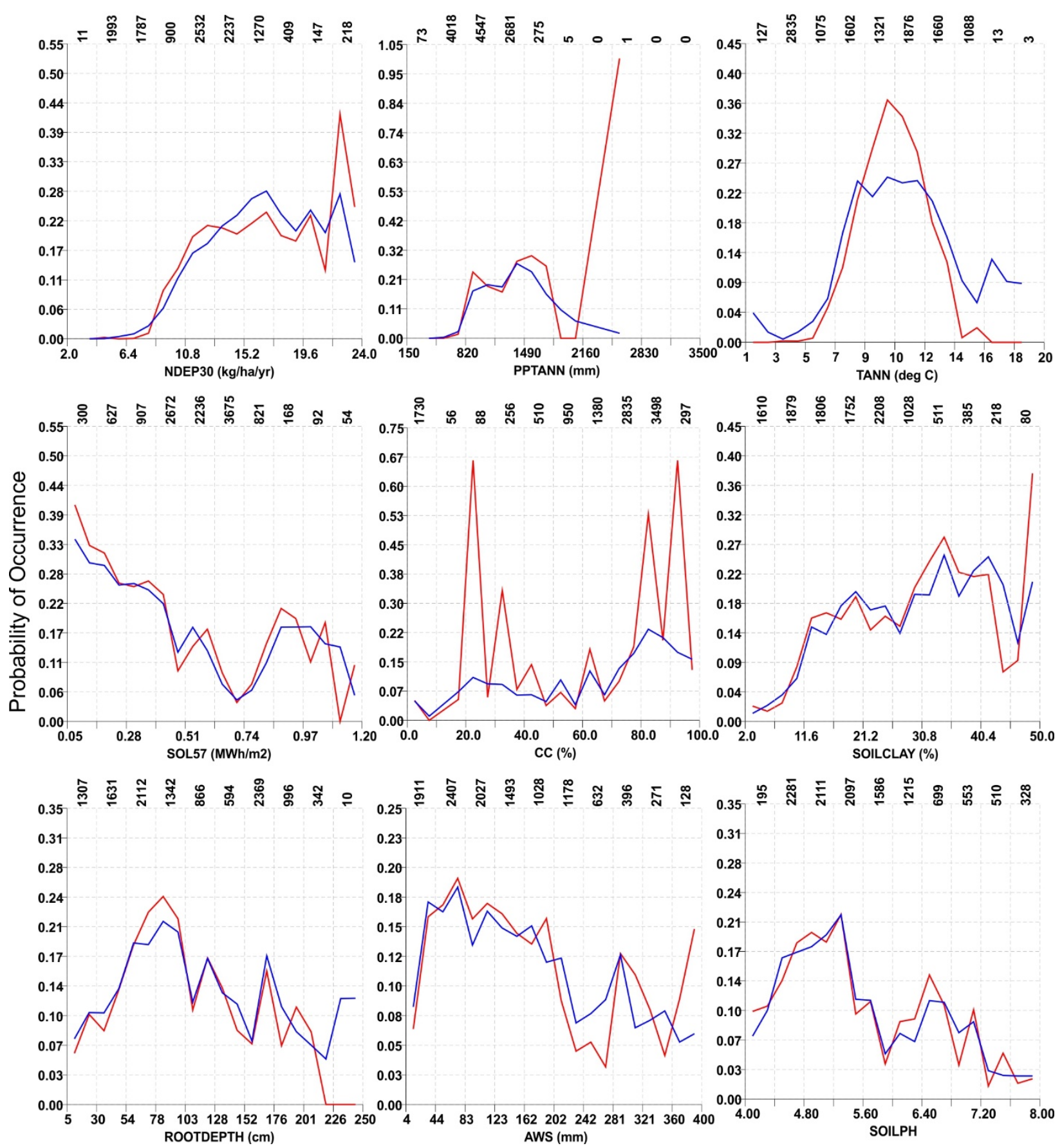


\section{4 (Dennstaedtia punctilobula)}

\section{- Observed - Modelled}
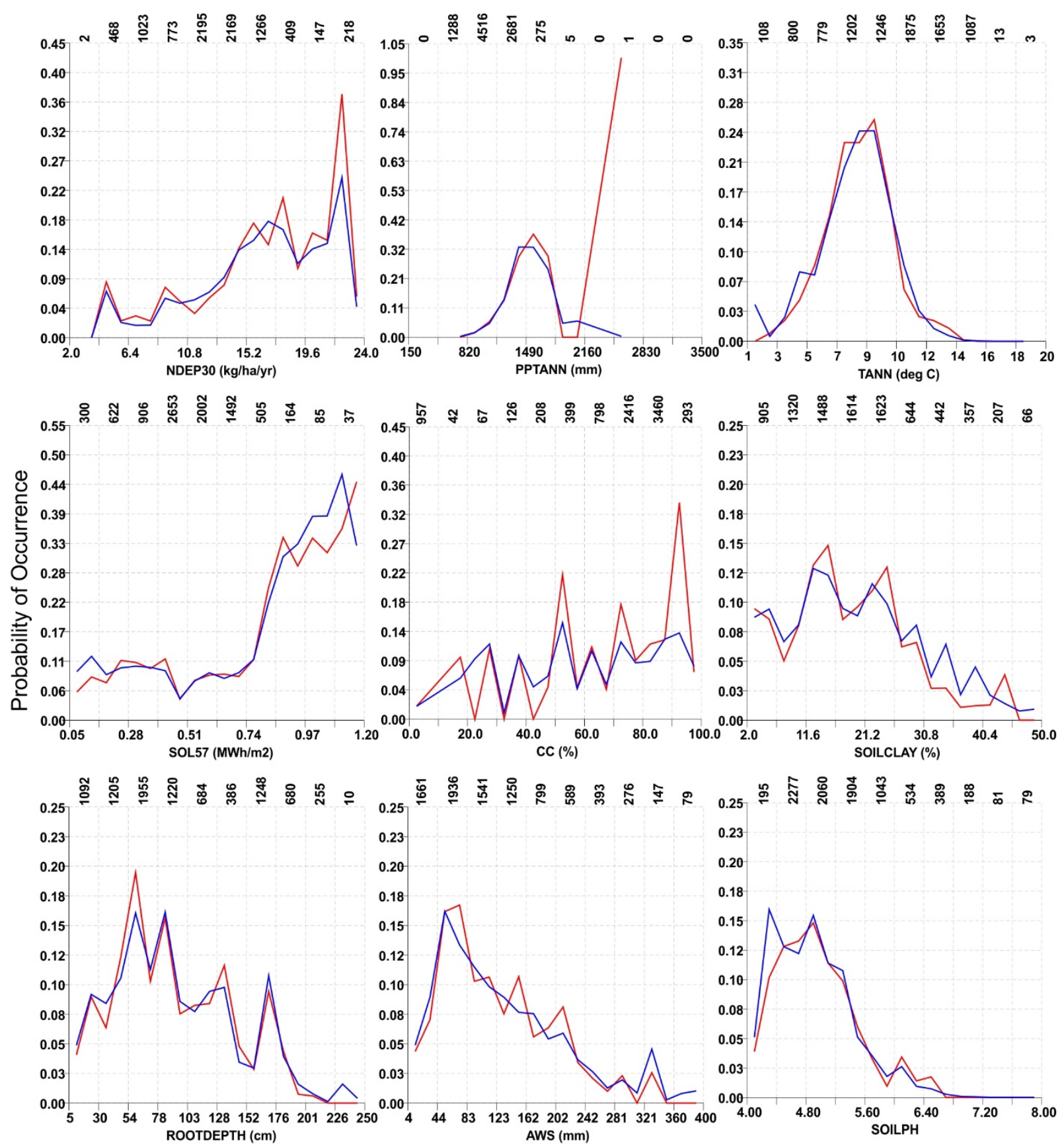

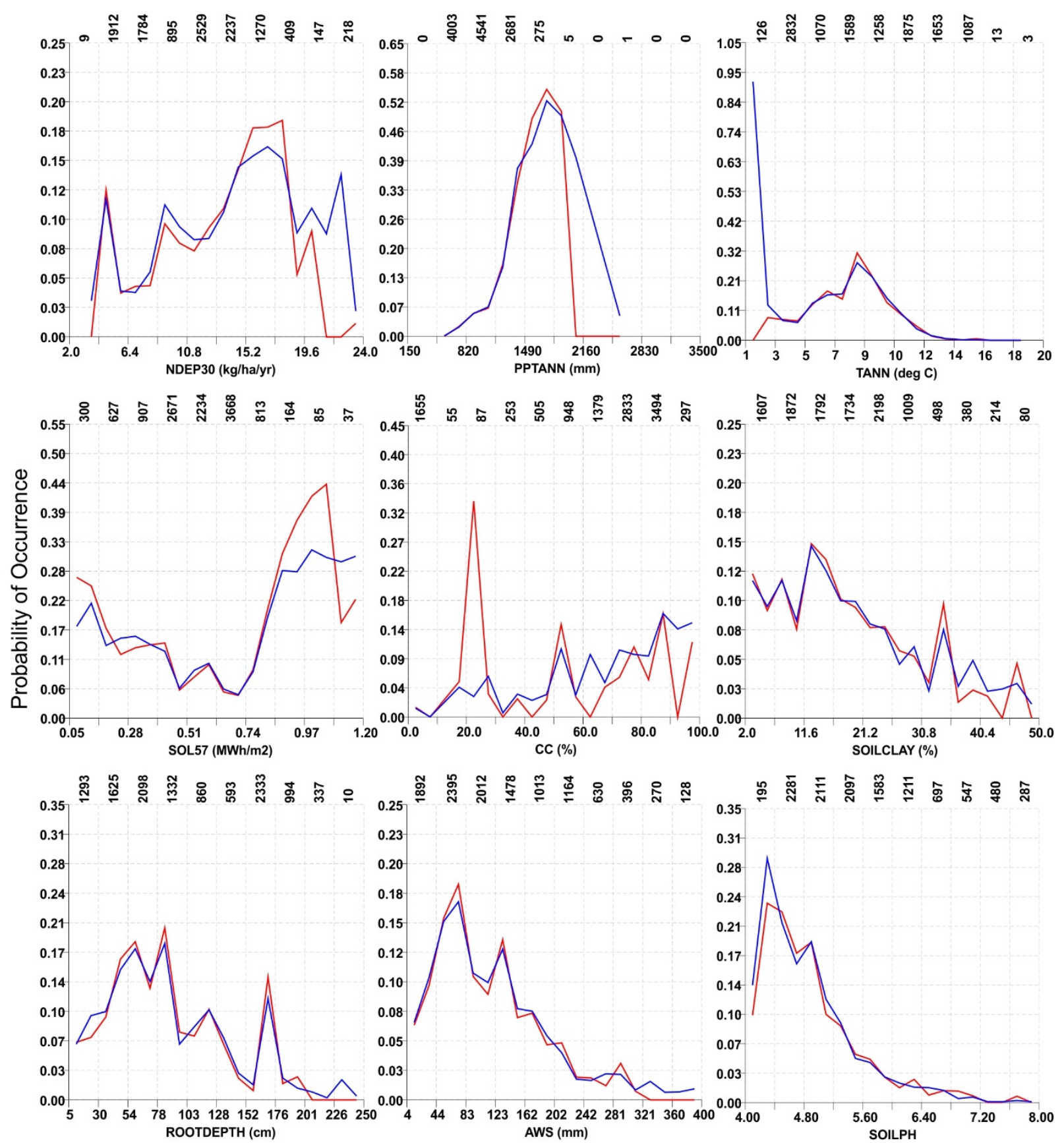

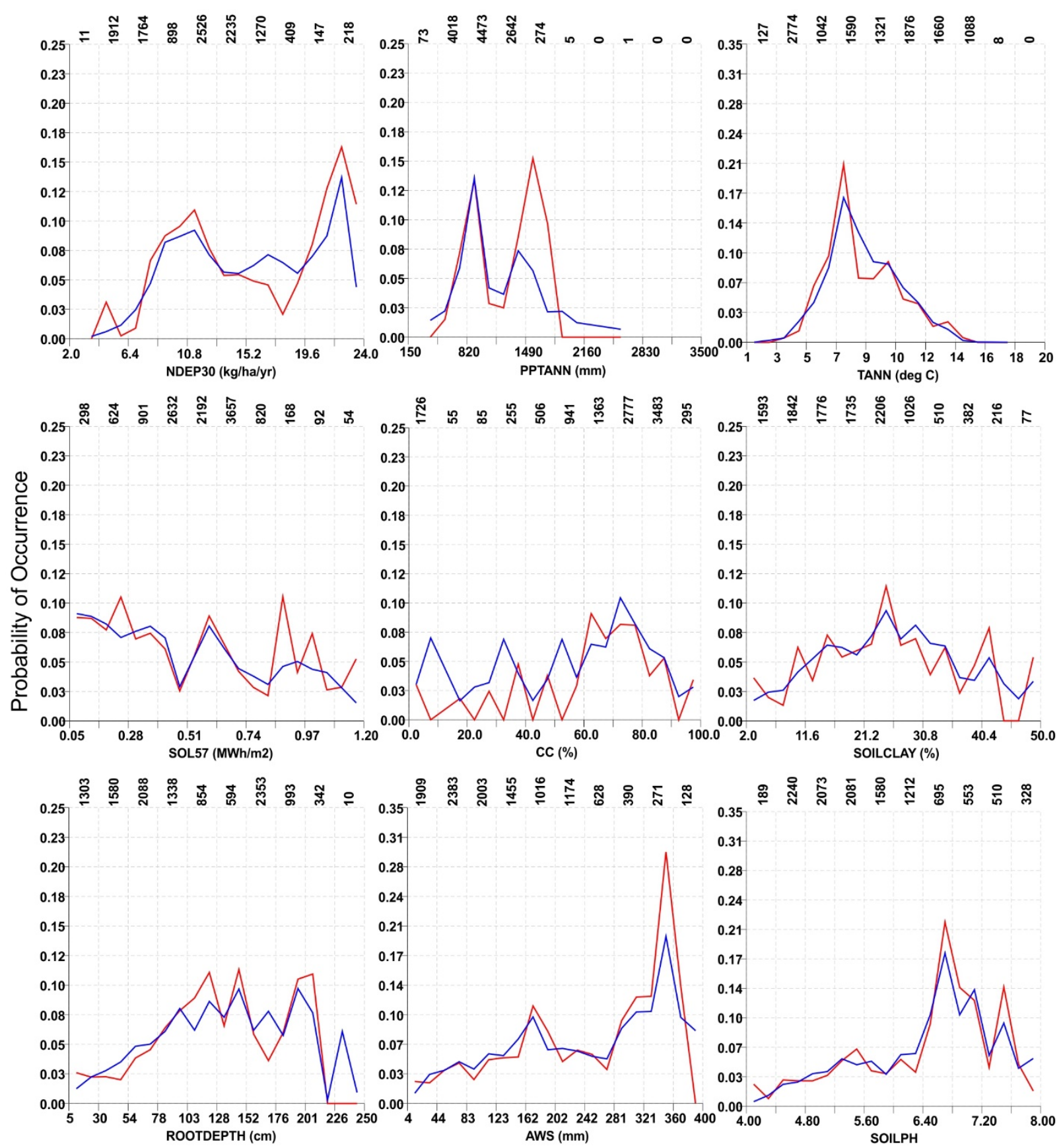

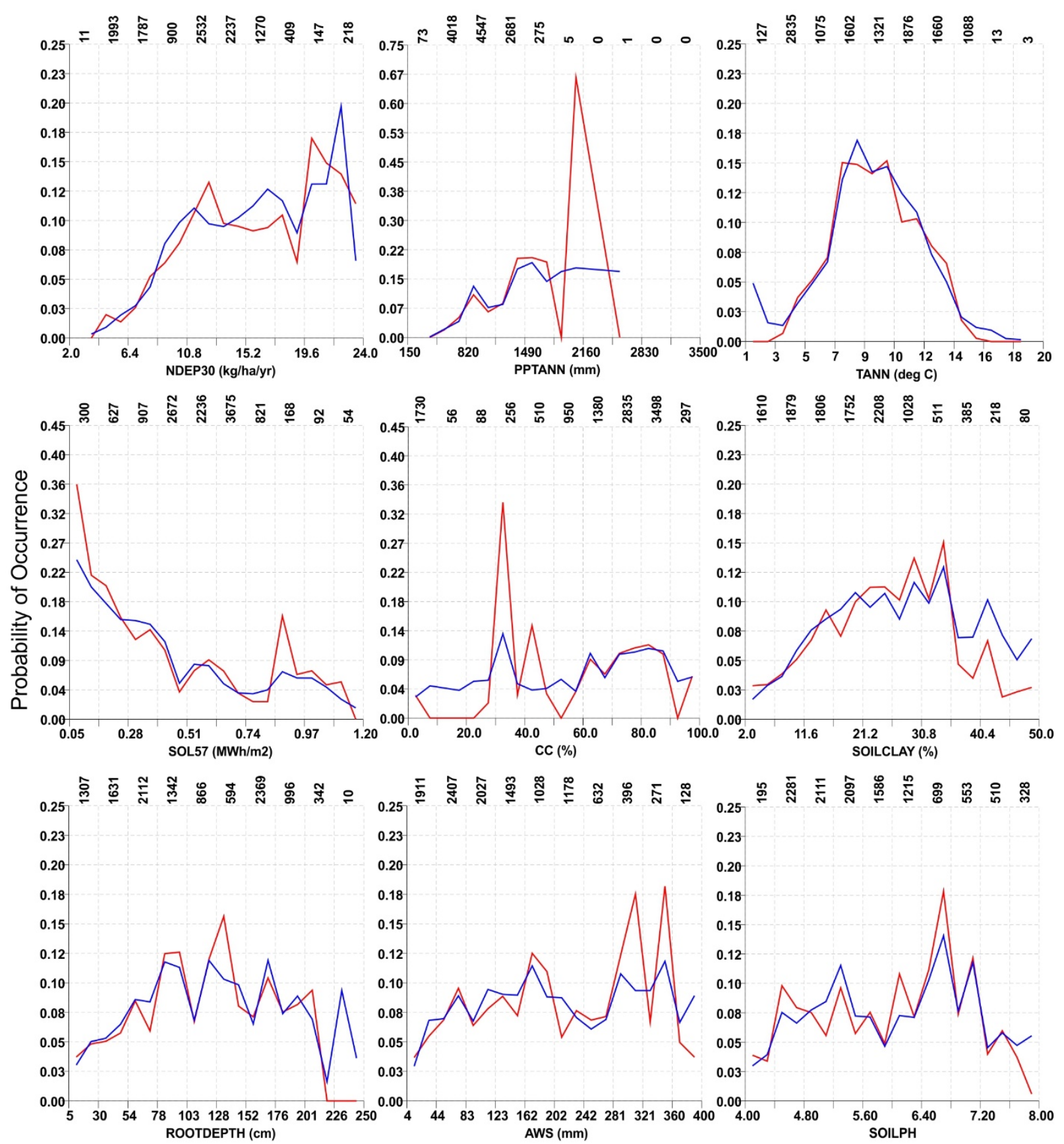


\section{6 (Maianthemum racemosum)}

\section{- Observed - Modelled}
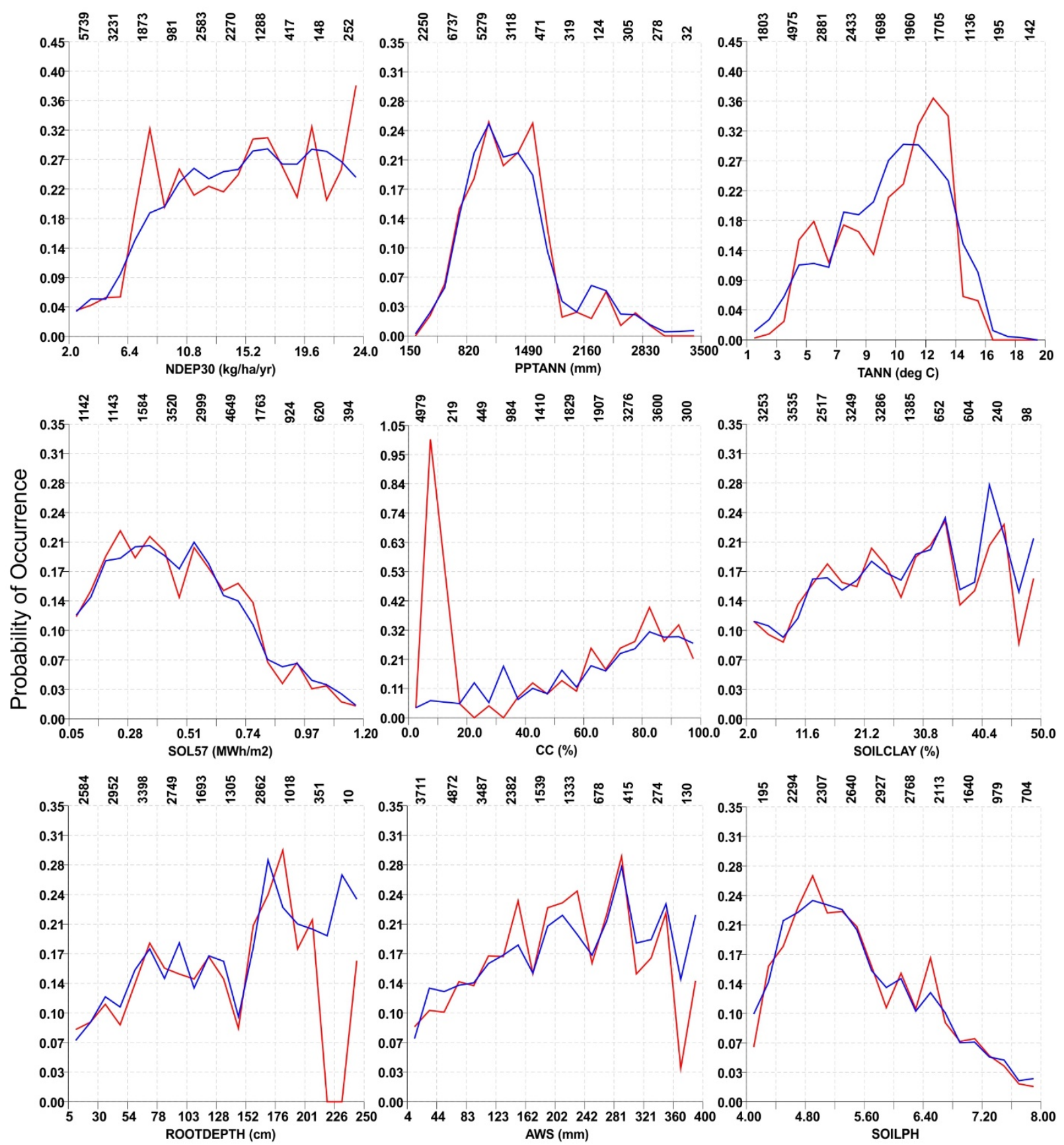

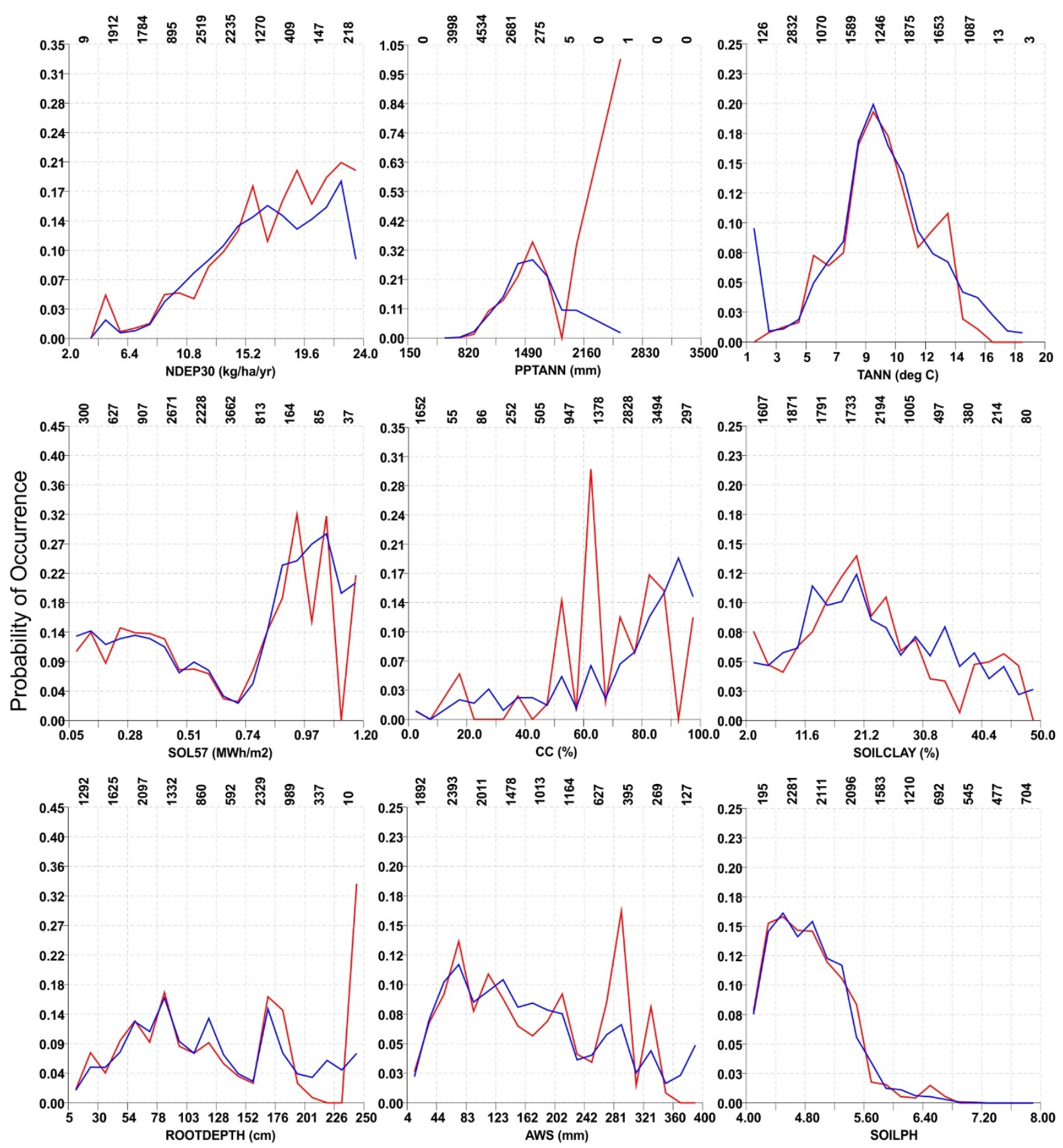

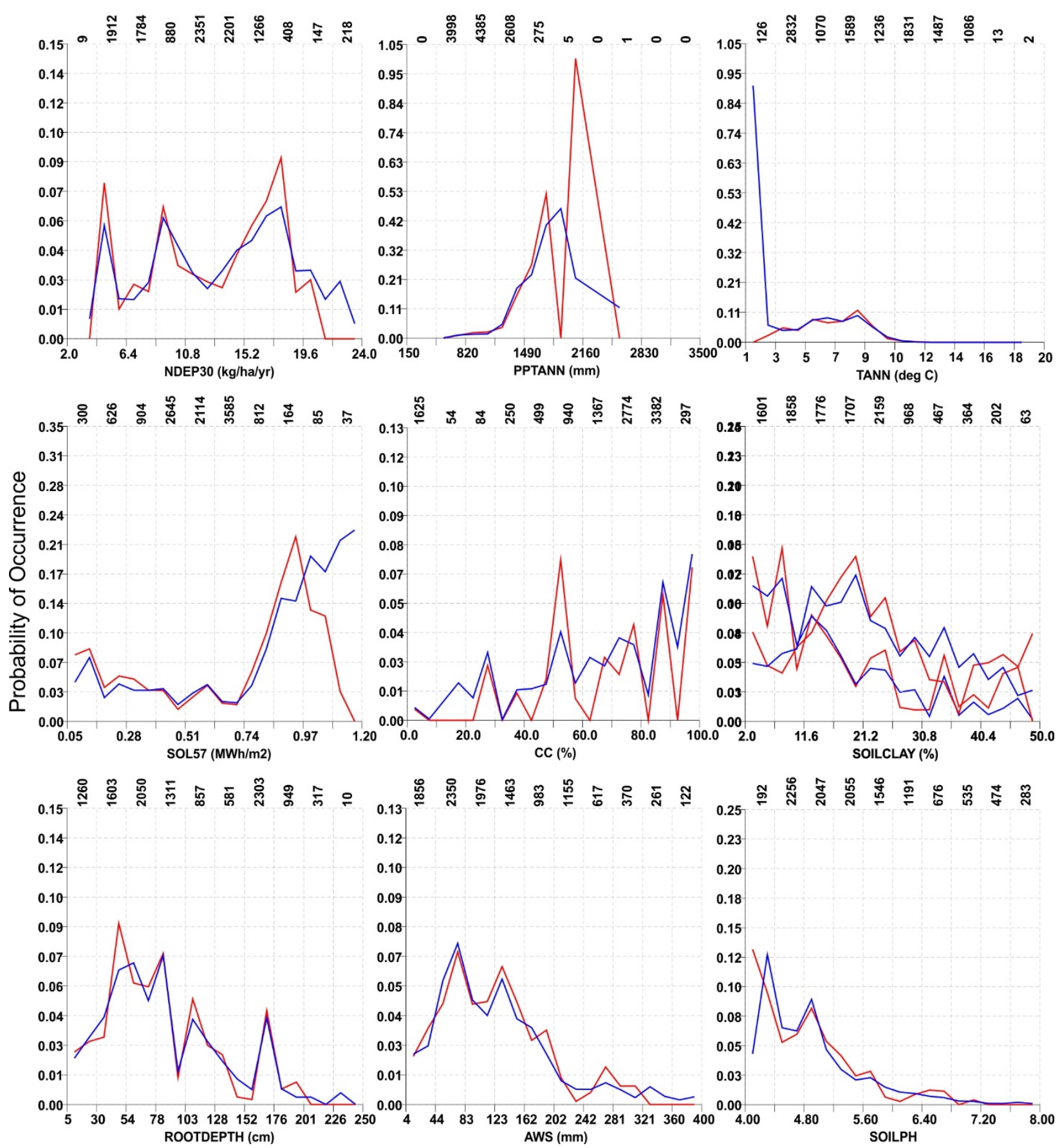

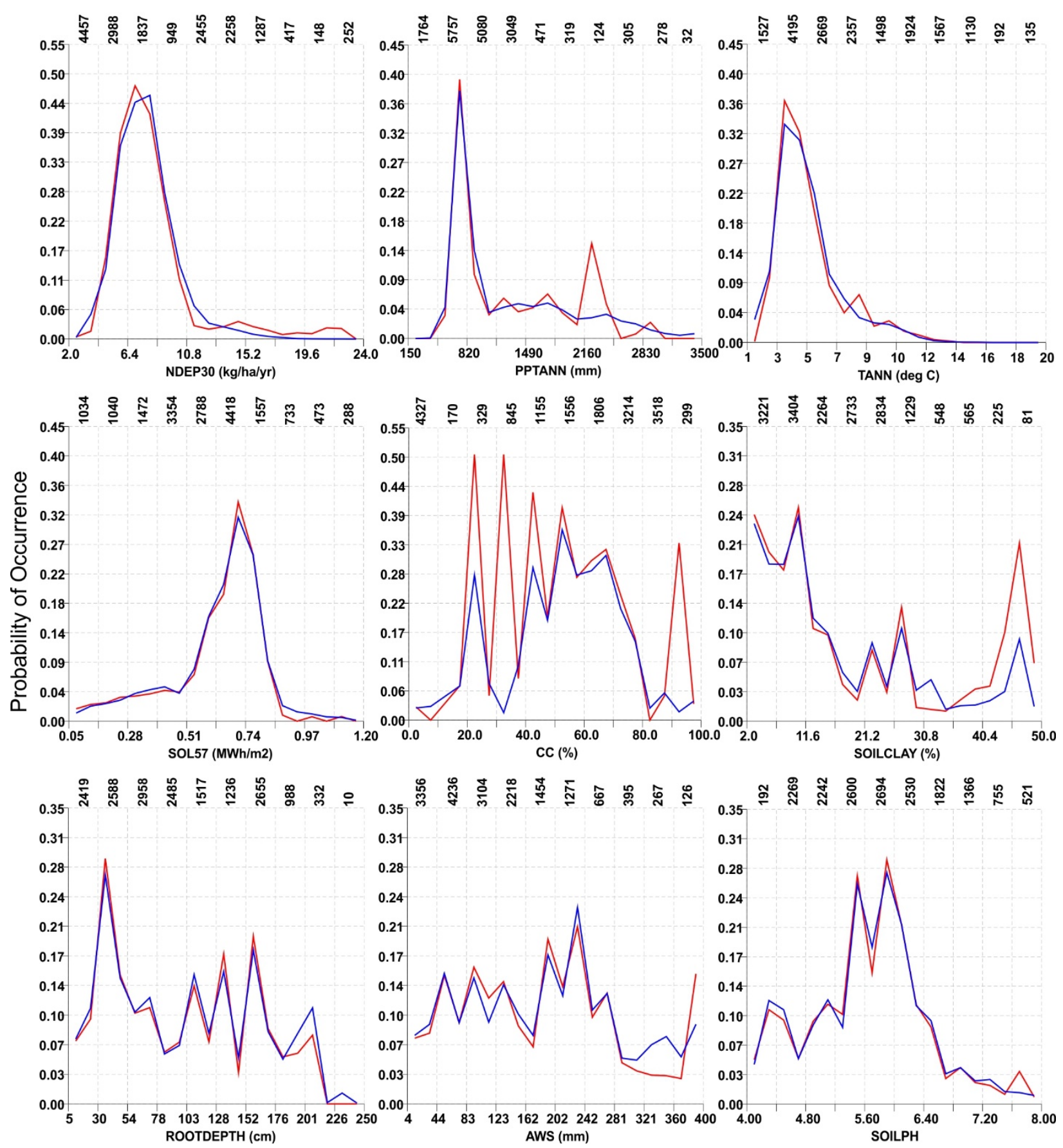

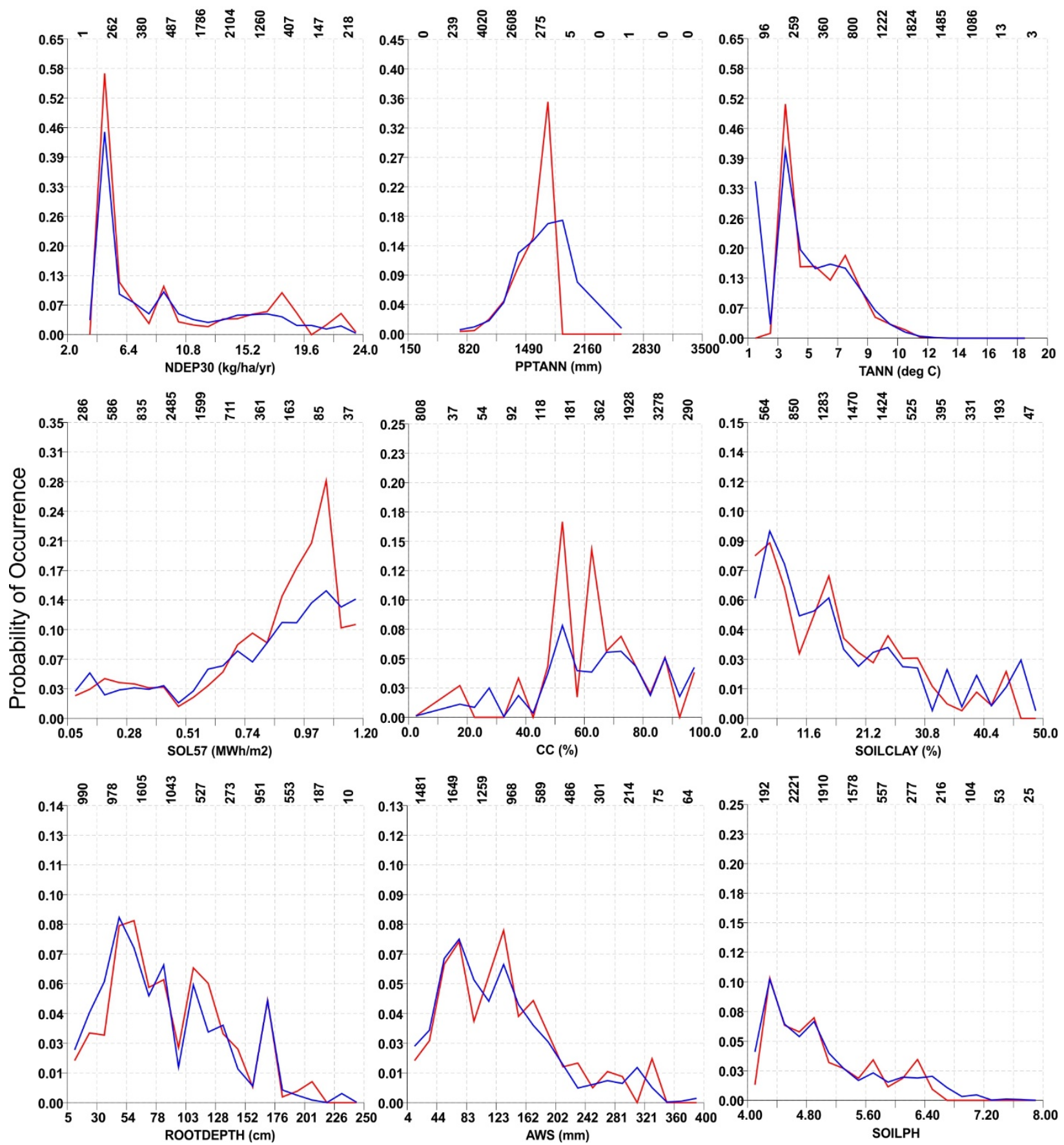
Supplemental Material 8. Hosmer-Lemeshow (H-L) test results of US-PROPS v2 models for indicator species at HB, PR, and CC. Plots show summed predicted (y-axis) and observed (xaxis) probabilities, grouped $(n=20)$ from smallest to largest observed probability, among the vegetation survey sites used for US-PROPS v2 model development. For a perfect fit, the black line should coincide with the red $y=x$ line. The title of each plot provides the chi-squared value (Pear) and its p-value.

The test was typically highly significant, which is mostly due to the relatively large number of sites used for model development. This is not a particular feature of the selected US-PROPS v2 models, but will always be the case when the number of sites is sufficiently large. Therefore, a continuous version of the H-L test was also used to evaluate model fit. Results generally showed good agreement, with the exception of 32010 where probabilities were underpredicted at low values and overpredicted at large values. 
Species 10020

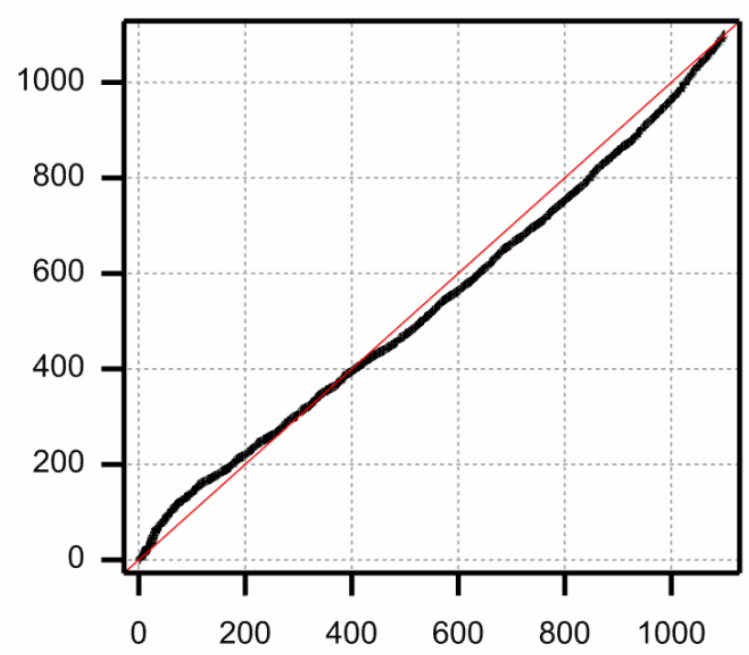

Species 10070

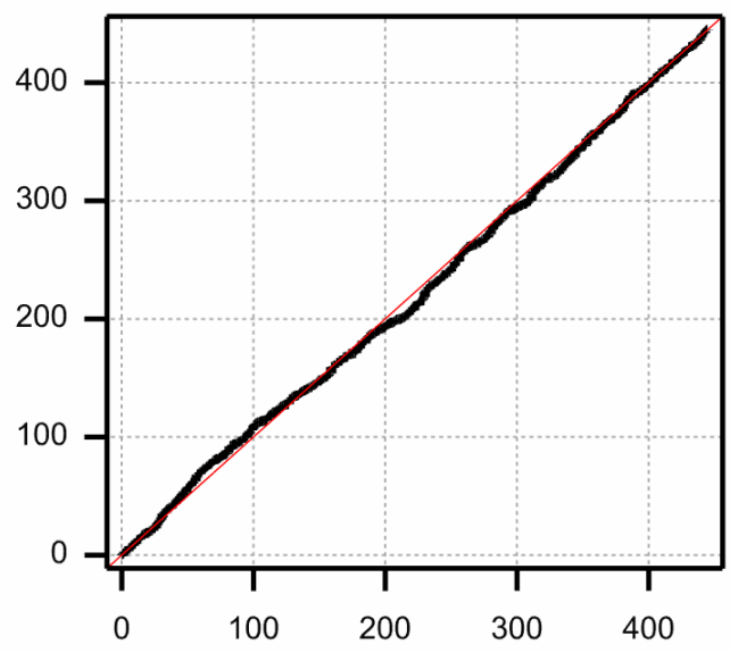

Species 10125

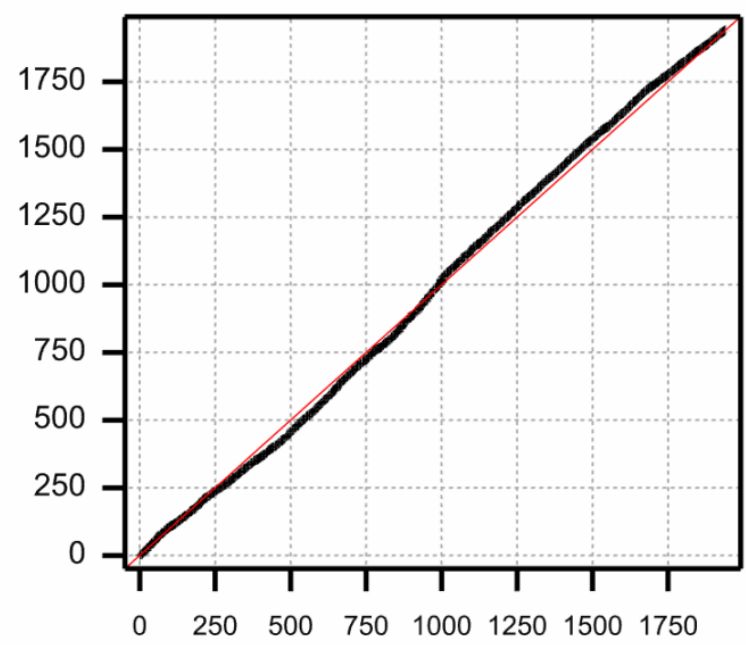

Species 10024

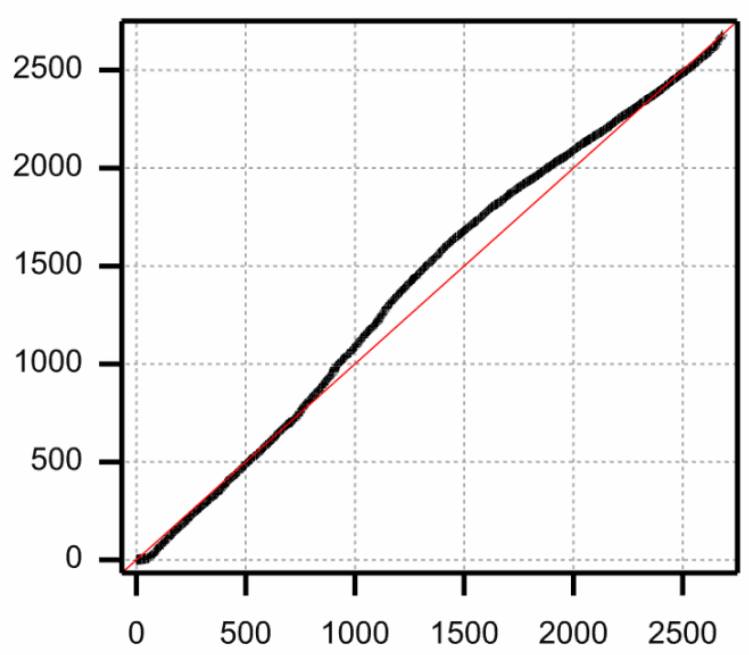

Species 10120

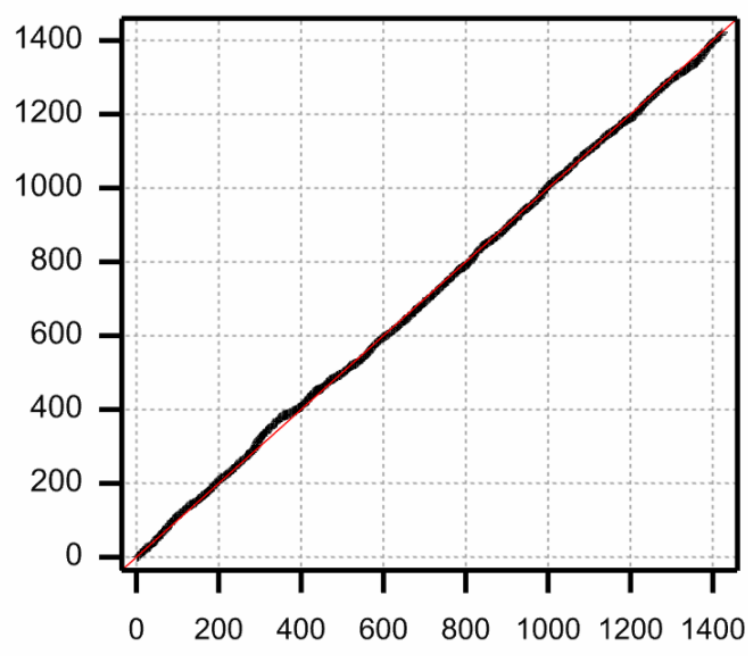

Species 10201

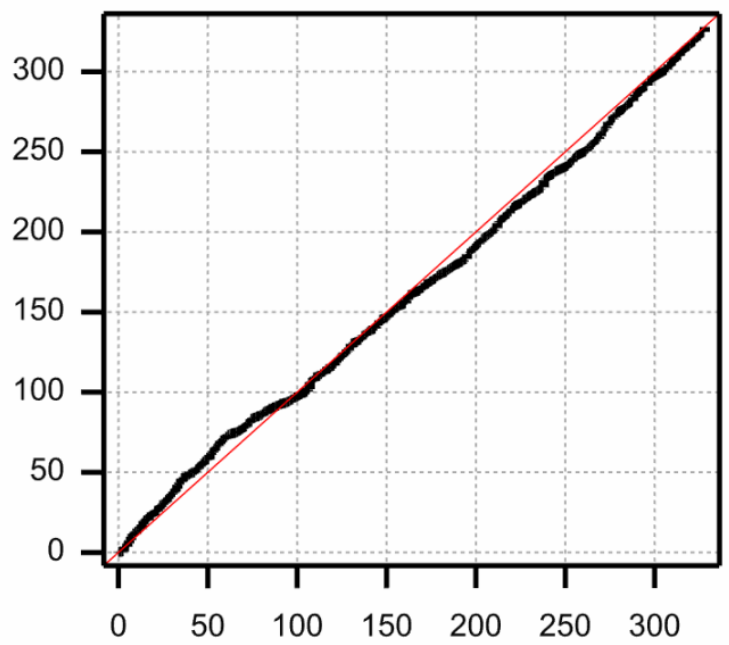


Species 10241

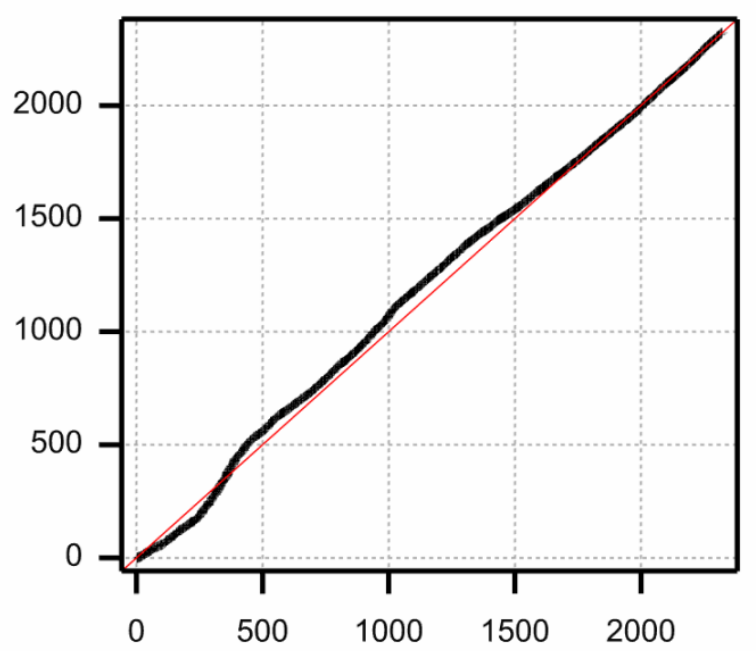

Species 10275

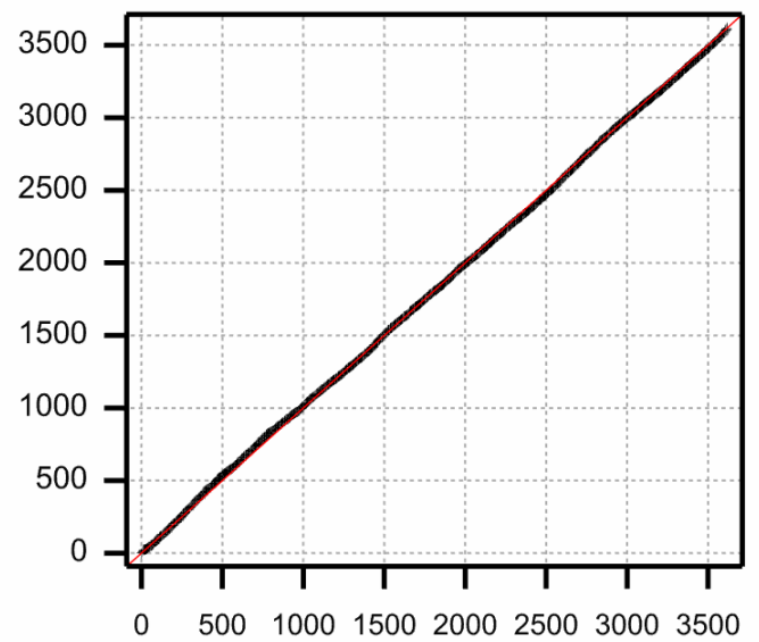

Species 30052

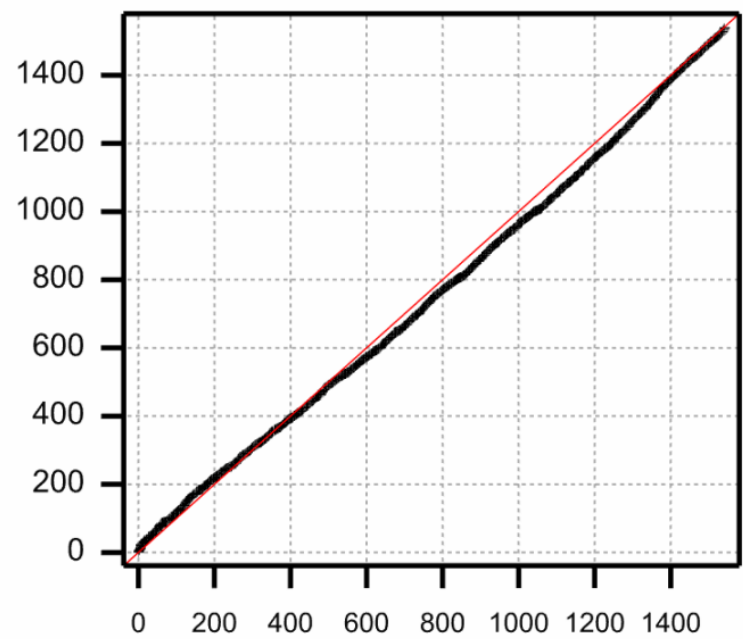

Species 10248

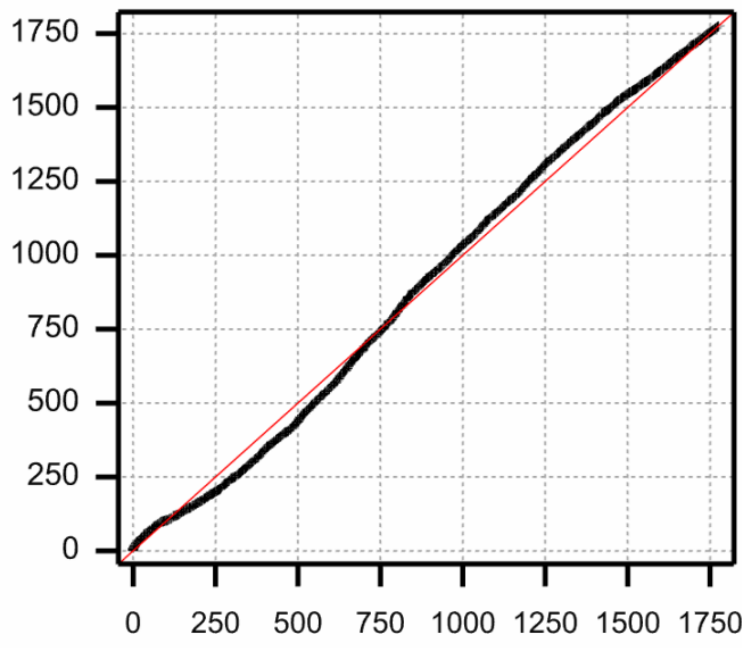

Species 30035

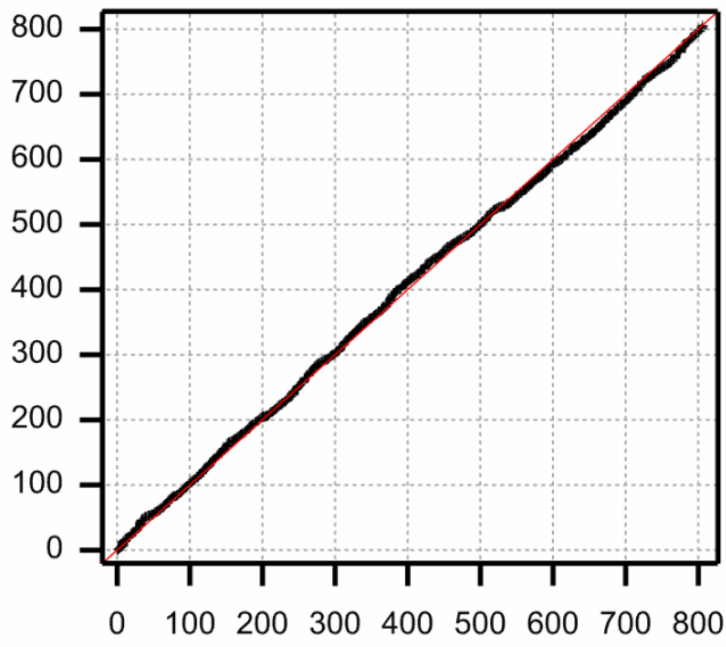

Species 31274

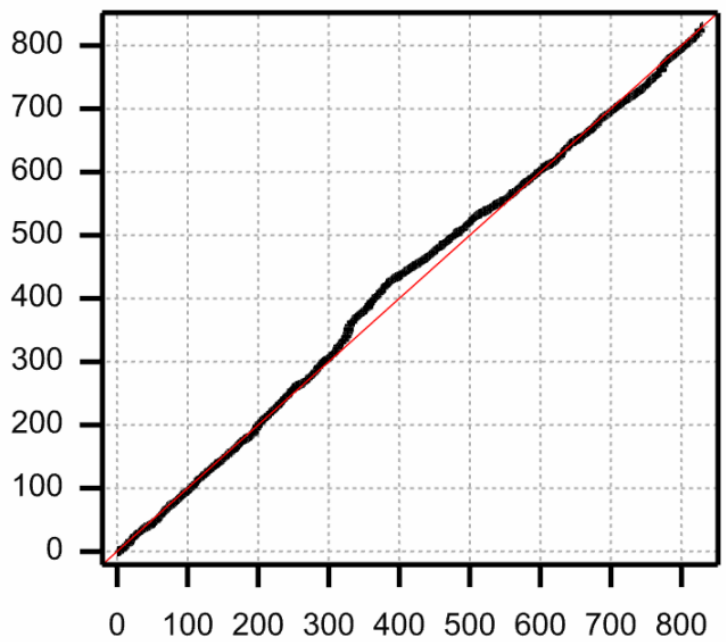


Species 31401

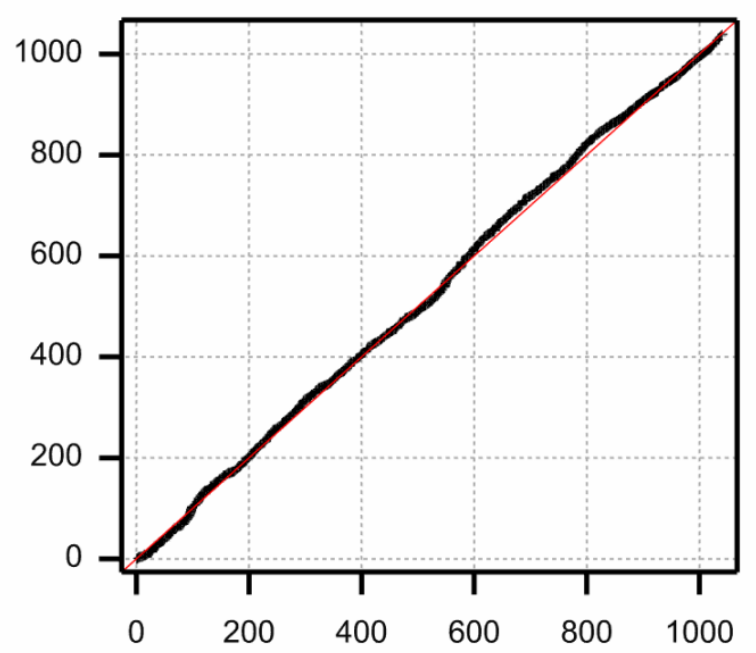

Species 32142

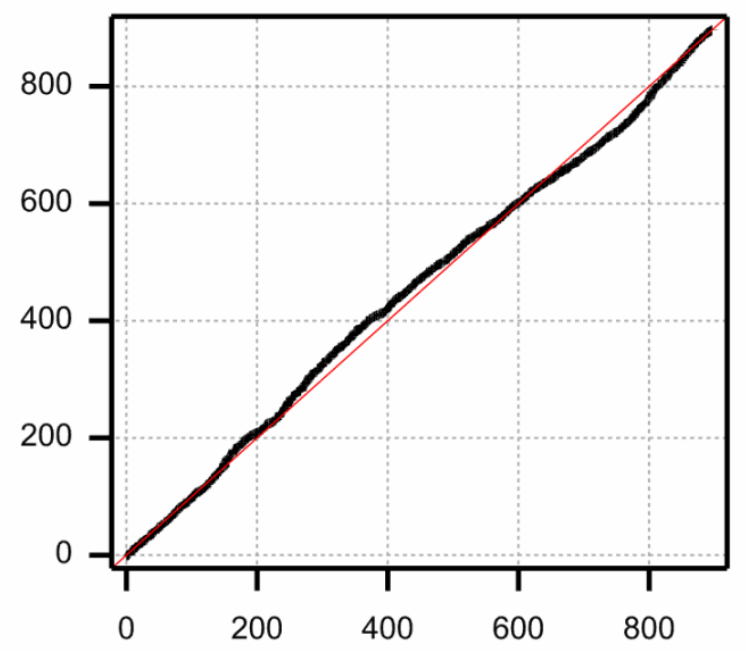

Species 32426

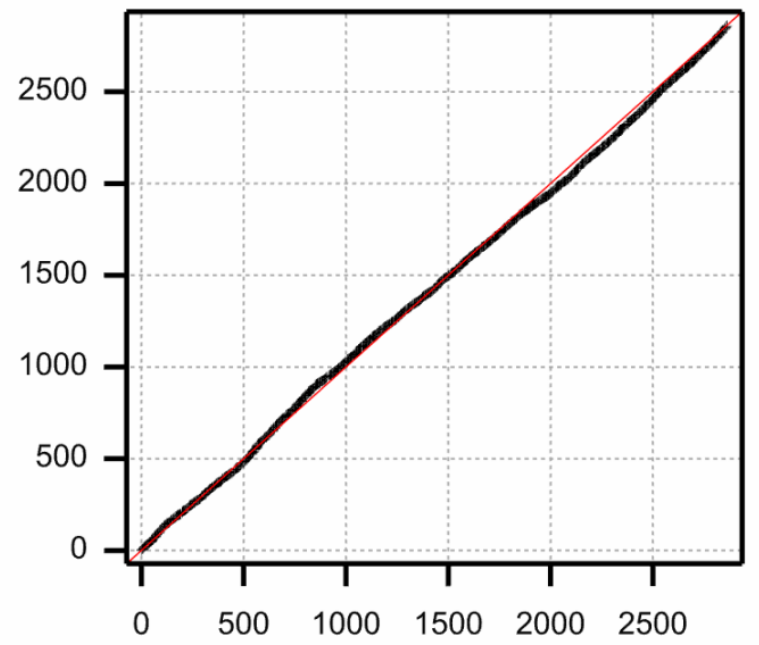

Species 32010

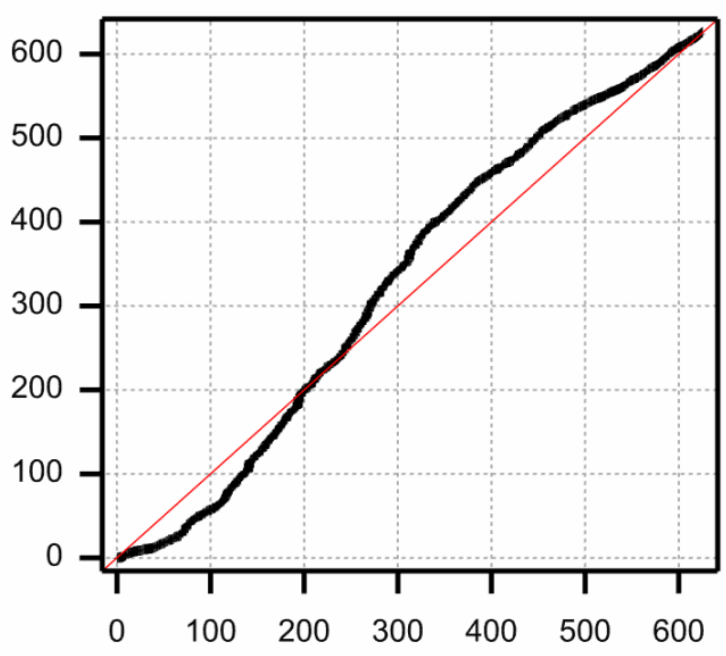

Species 32424

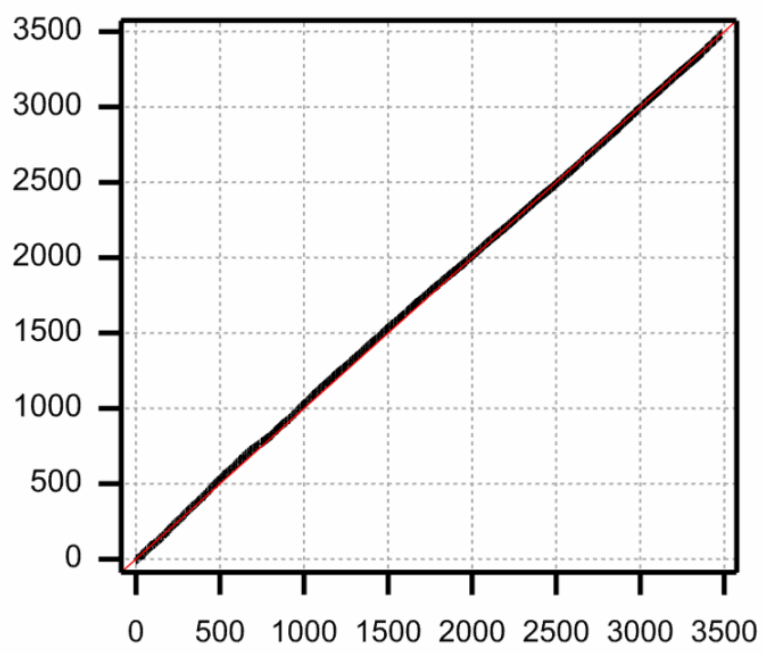

Species 32442

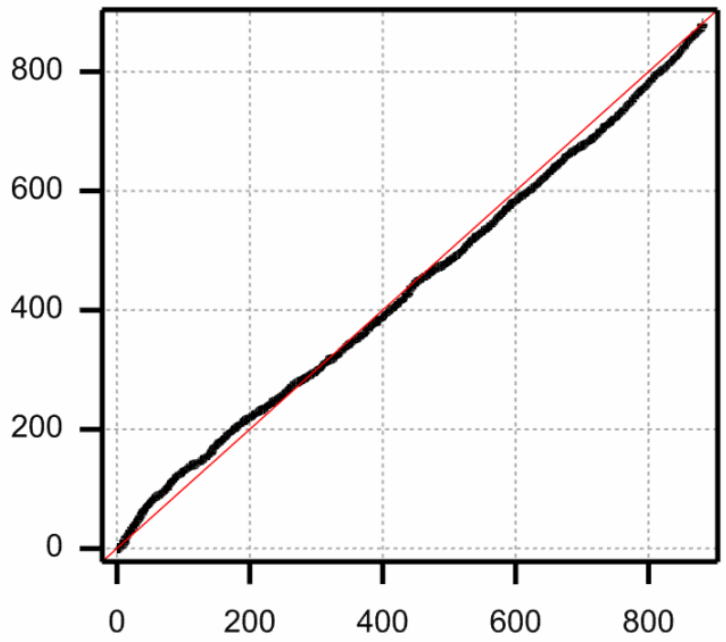


Species 32692

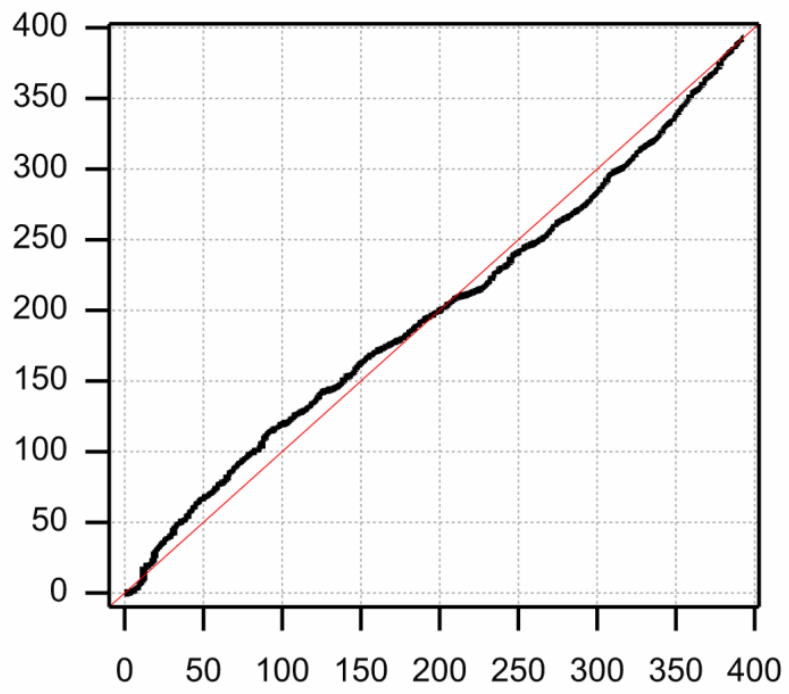

Species 33786

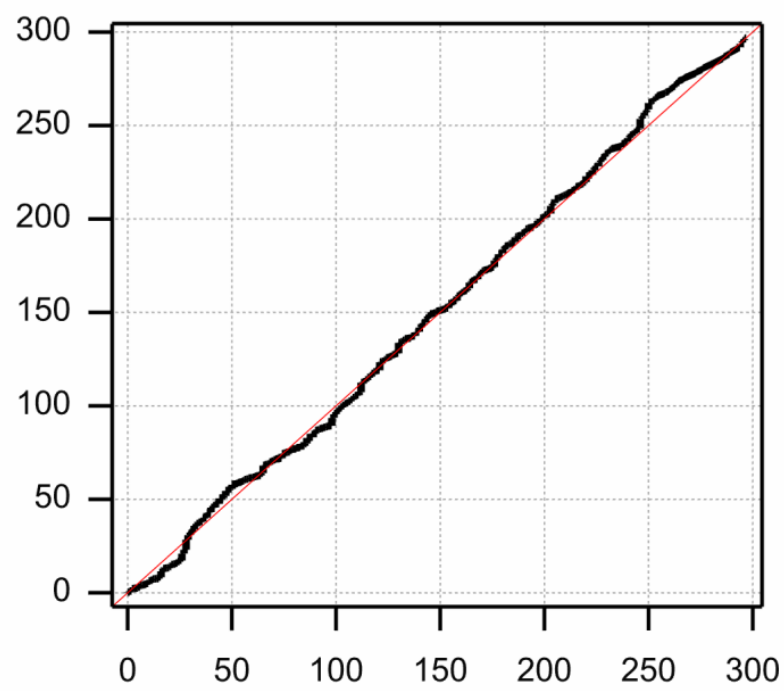

Species 33750

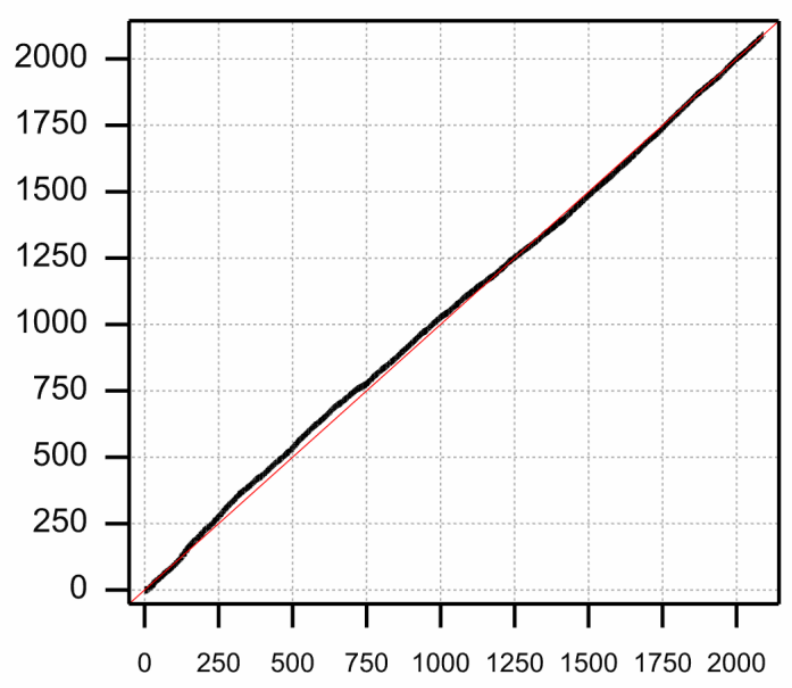


Supplemental Material 9. Critical load functions (CLFs) to attain occurrence probability of $75 \%$ (solid white line) and $95 \%$ (dashed white line) of the maximum occurrence probability for indicator species at Hubbard Brook (HB), Piney River (PR), and Cosby Creek (CC). The red dashed lines are shown to indicate the extent to which the CLF occurs within the bounds of data used for developing the species niche model. For some species, the CLF extends beyond 3,000 eq/ha/yr (300 meq/m²/yr; $42 \mathrm{~kg} \mathrm{~N} / \mathrm{ha} / \mathrm{yr} ; 48 \mathrm{~kg} \mathrm{~S} / \mathrm{ha} / \mathrm{yr}$ ) and does not appear on the plot. 
Acer pensylvanicum - 75\% (left) and $95 \%$ (right) of maximum occurrence probability.
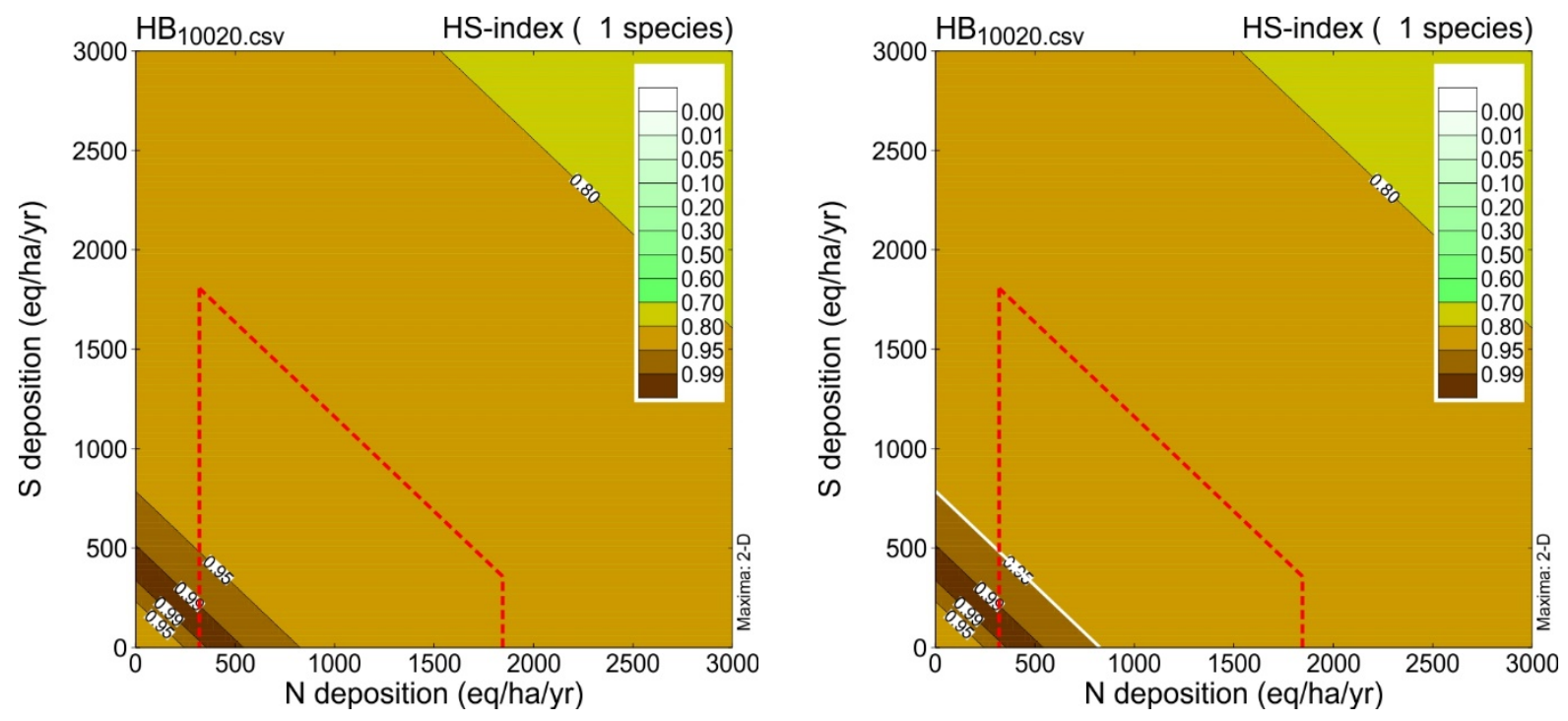

Acer saccharum - 75\% (left) and 95\% (right) of maximum occurrence probability.
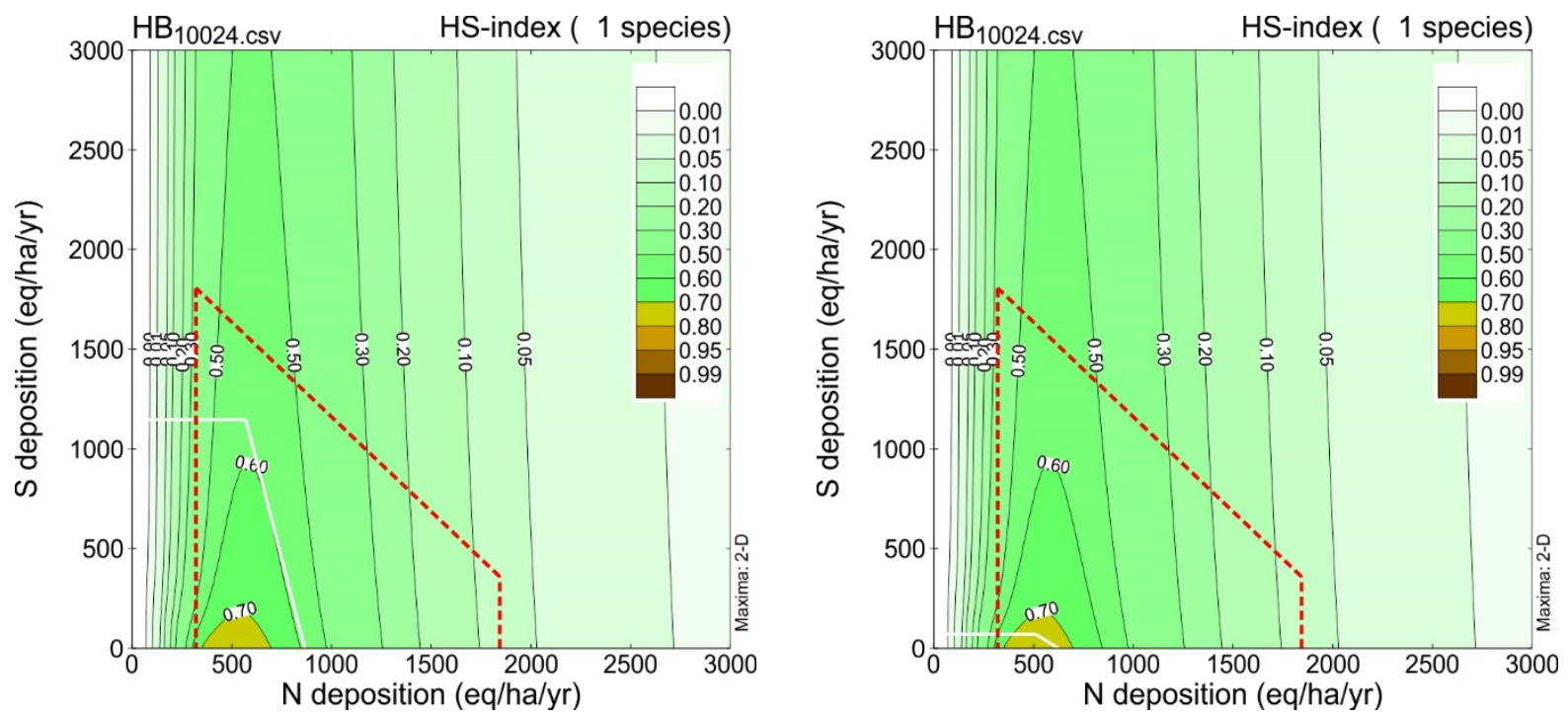
Fagus grandifolia-75\% (left) and 95\% (right) of maximum occurrence probability.
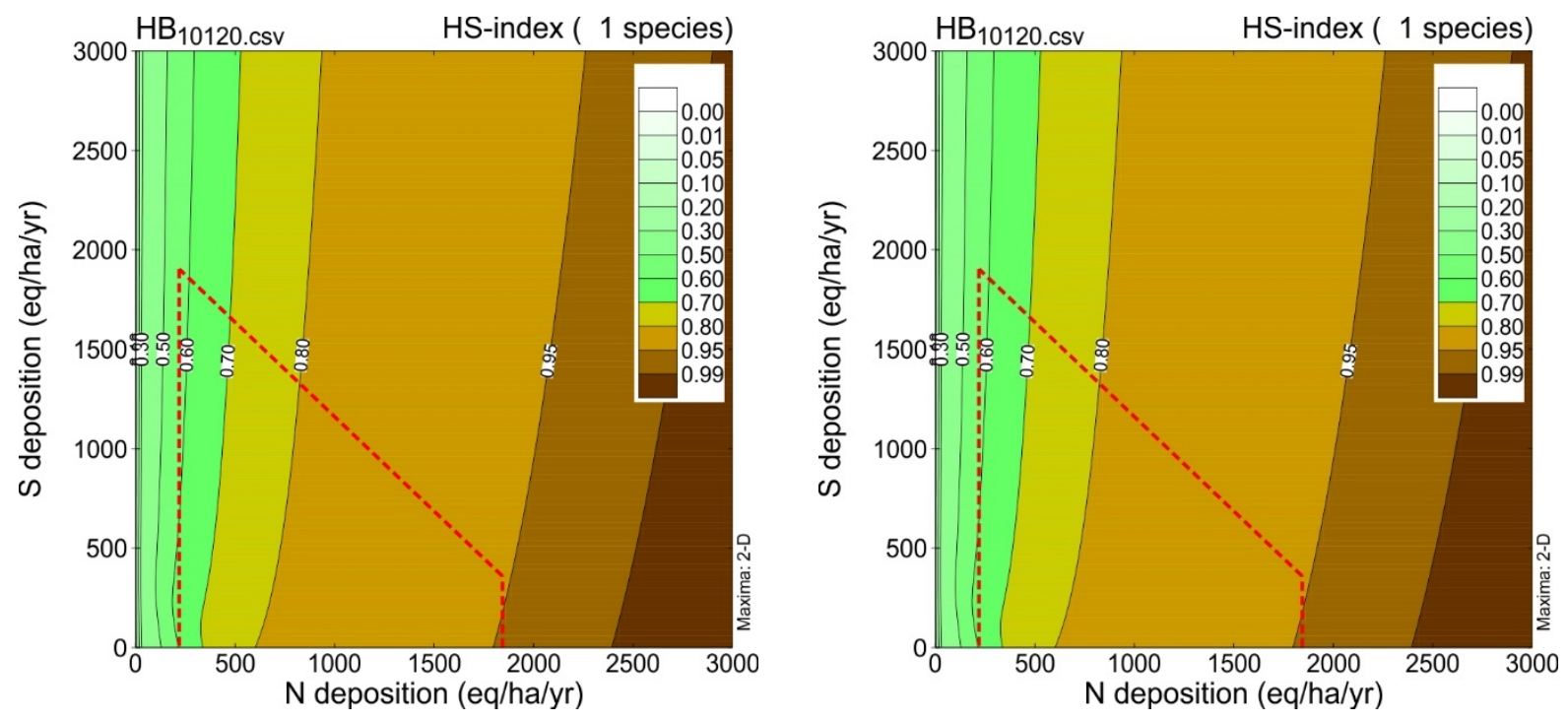

Fraxinus Americana-75\% (left) and 95\% (right) of maximum occurrence probability.
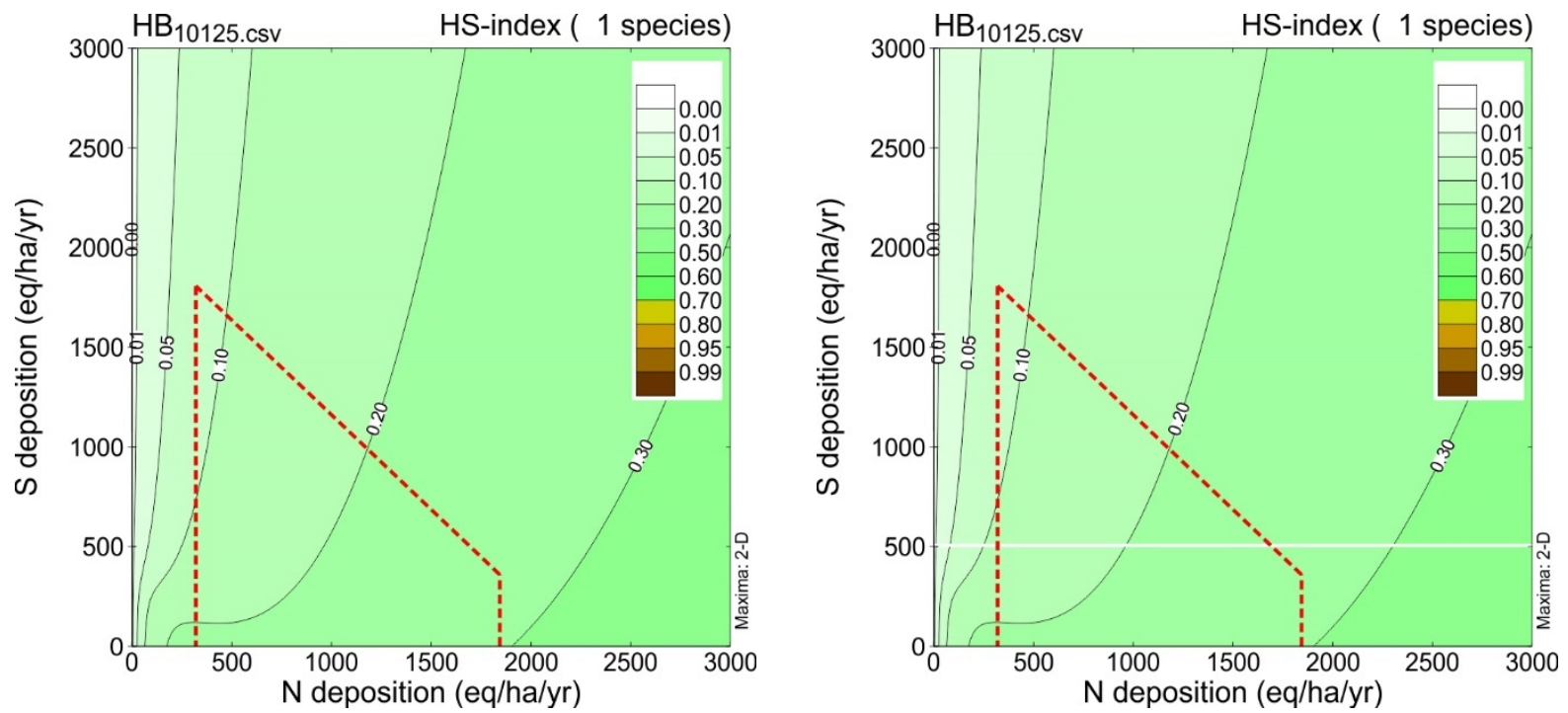
Picea rubens - $75 \%$ (left) and $95 \%$ (right) of maximum occurrence probability.
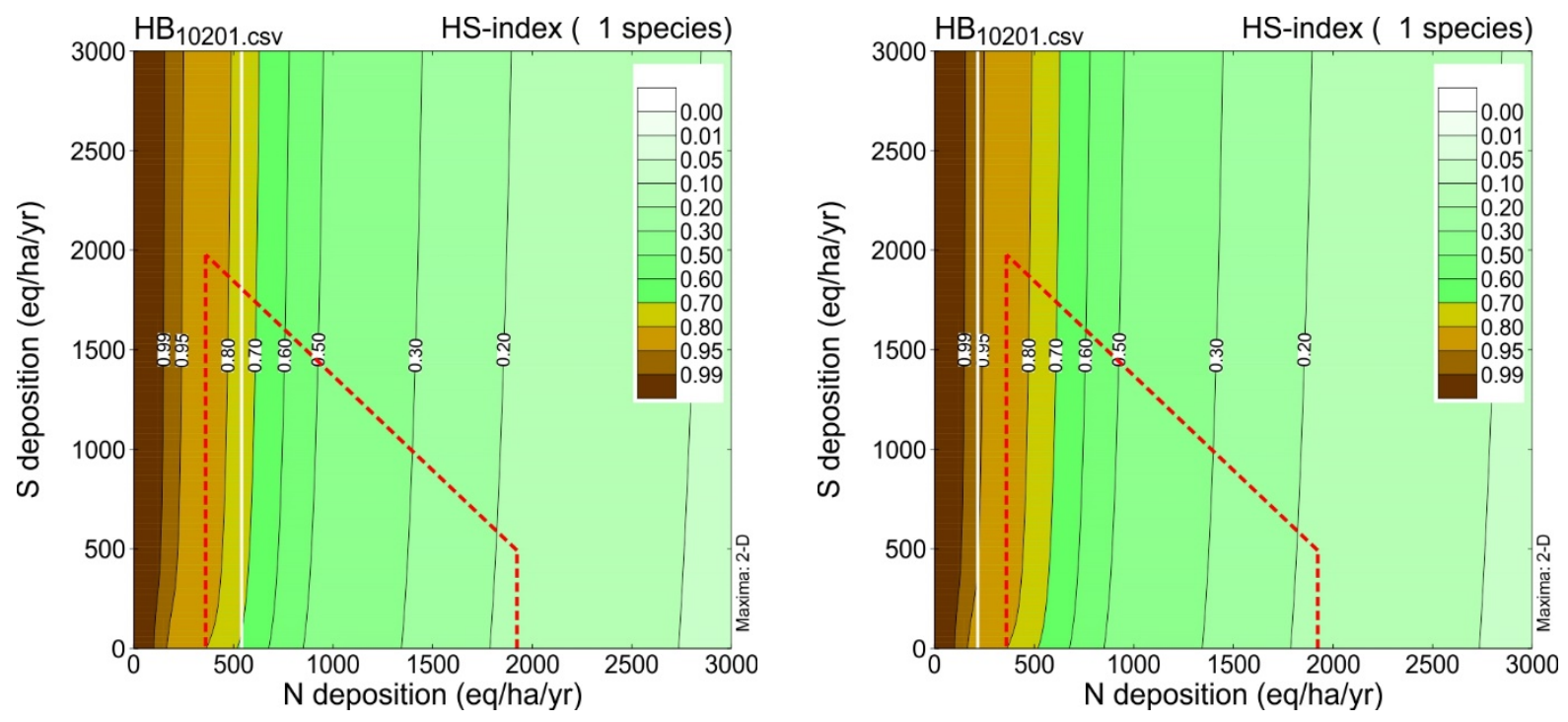

Dennstaedtia punctilobula - 75\% (left) and 95\% (right) of maximum occurrence probability.
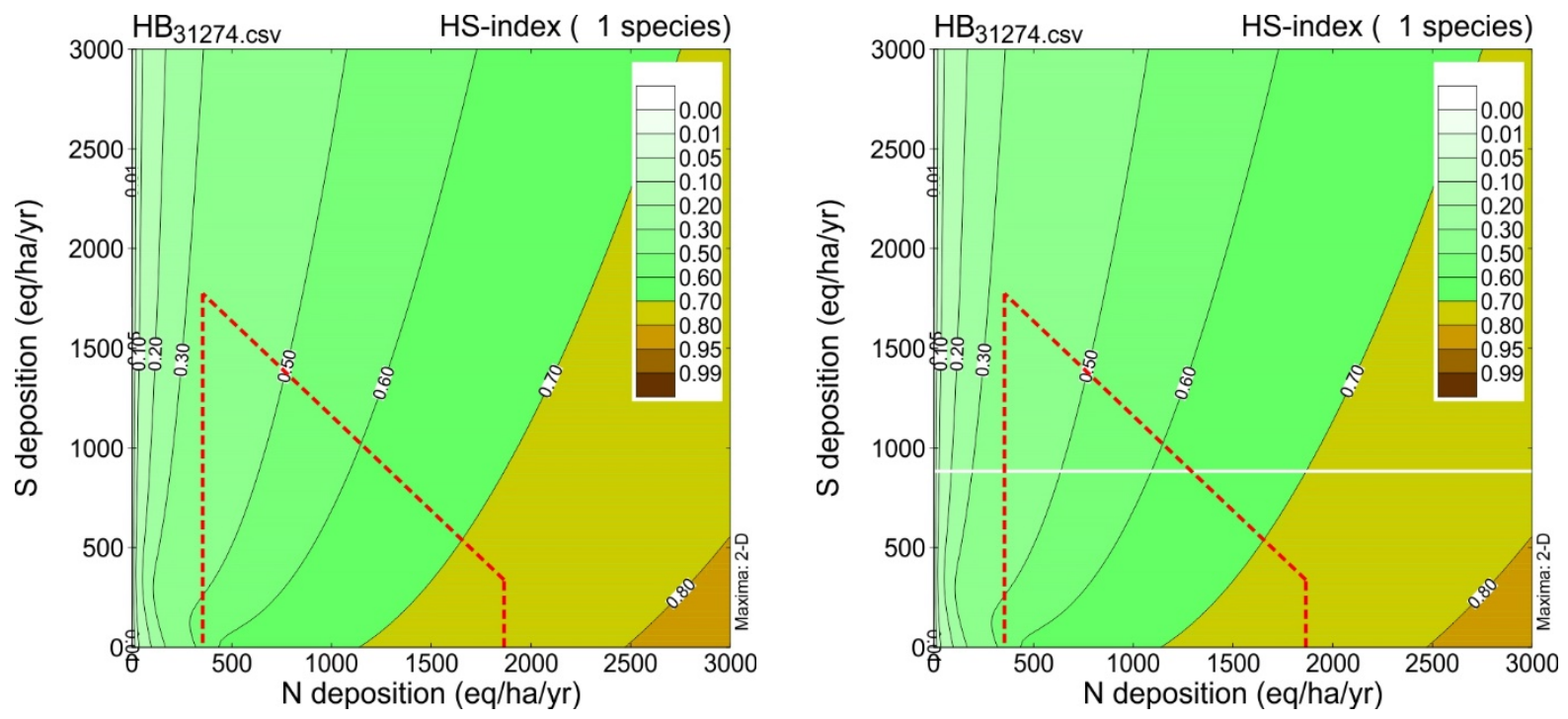
Dryopteris intermedia-75\% (left) and $95 \%$ (right) of maximum occurrence probability.
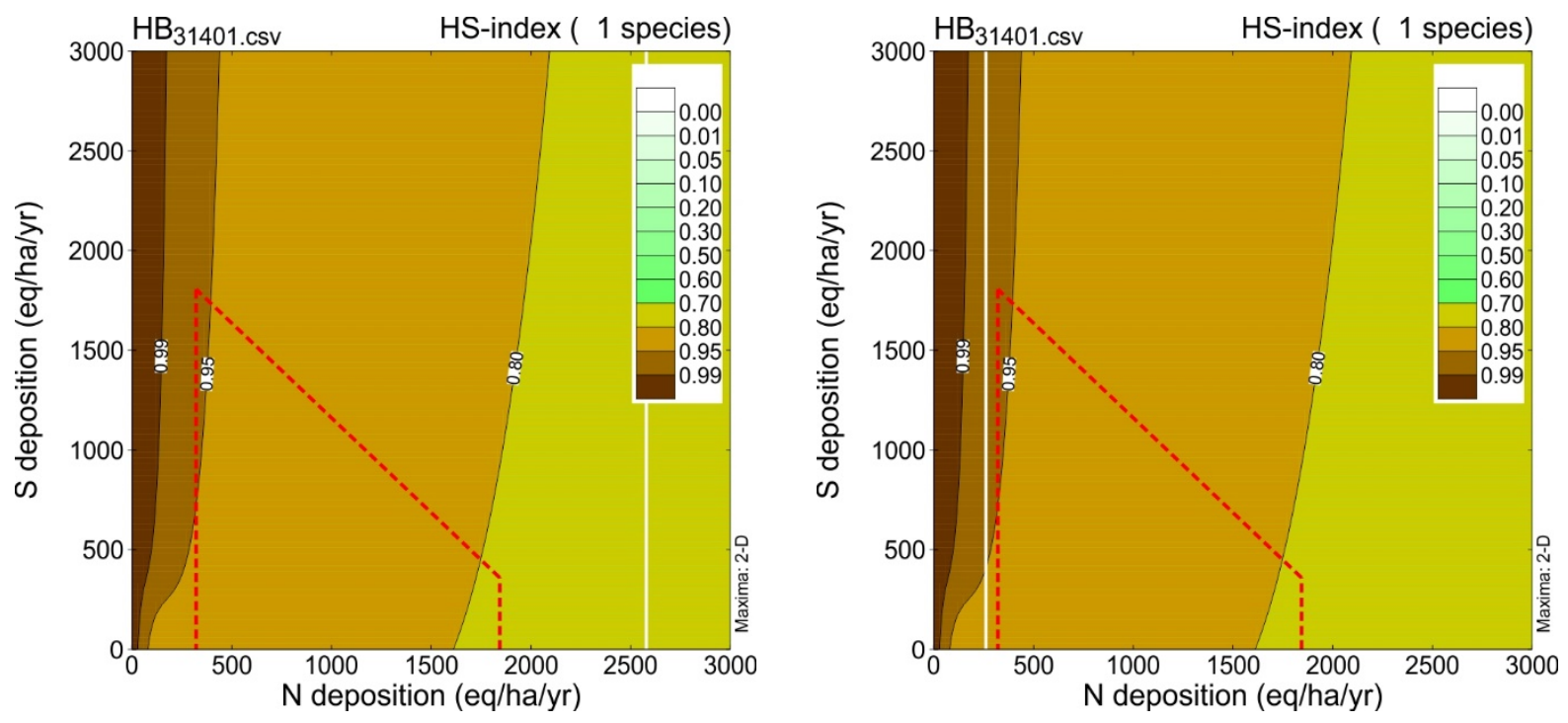

Maianthemum racemosum - 75\% (left) and 95\% (right) of maximum occurrence probability.
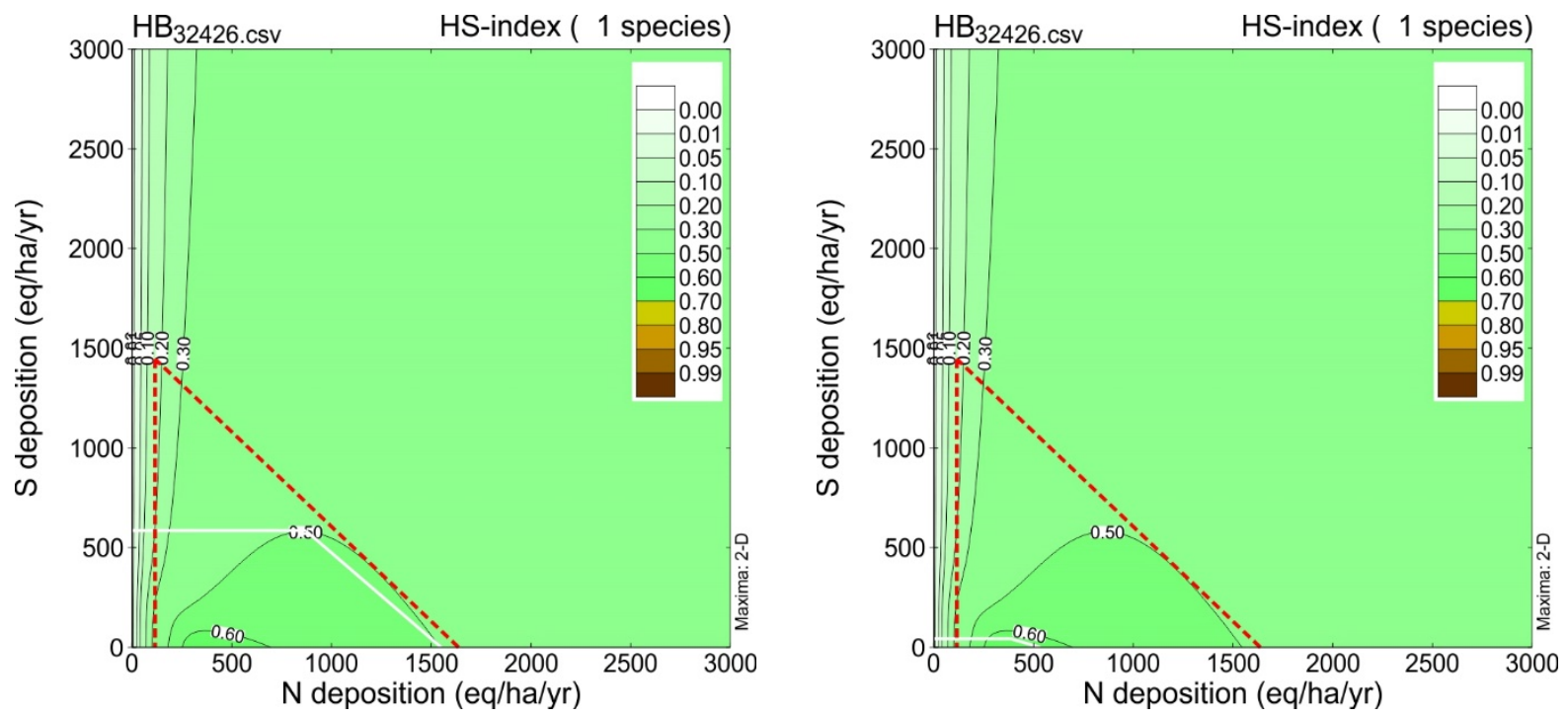
Medeola virginiana - $75 \%$ (left) and $95 \%$ (right) of maximum occurrence probability.
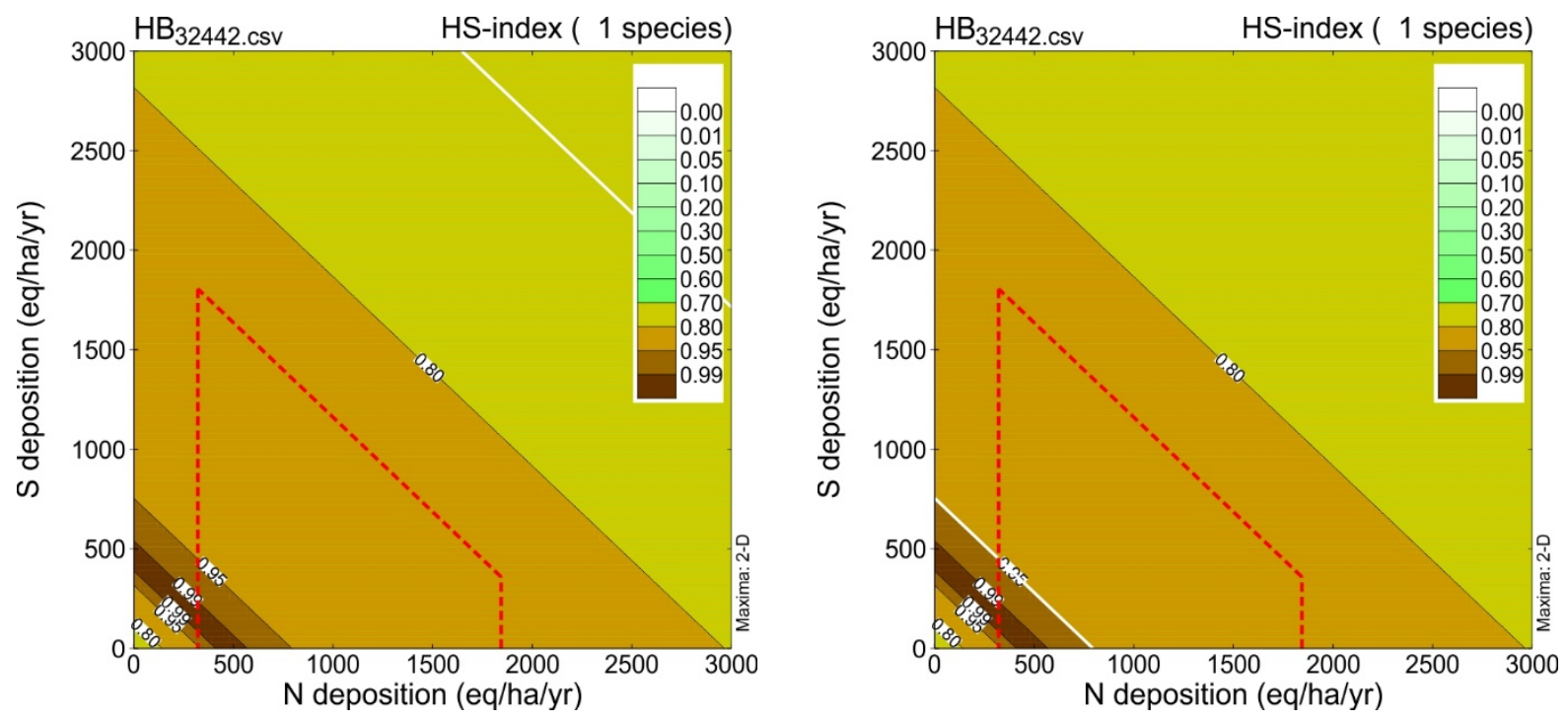

Oxalis montana-75\% (left) and $95 \%$ (right) of maximum occurrence probability.
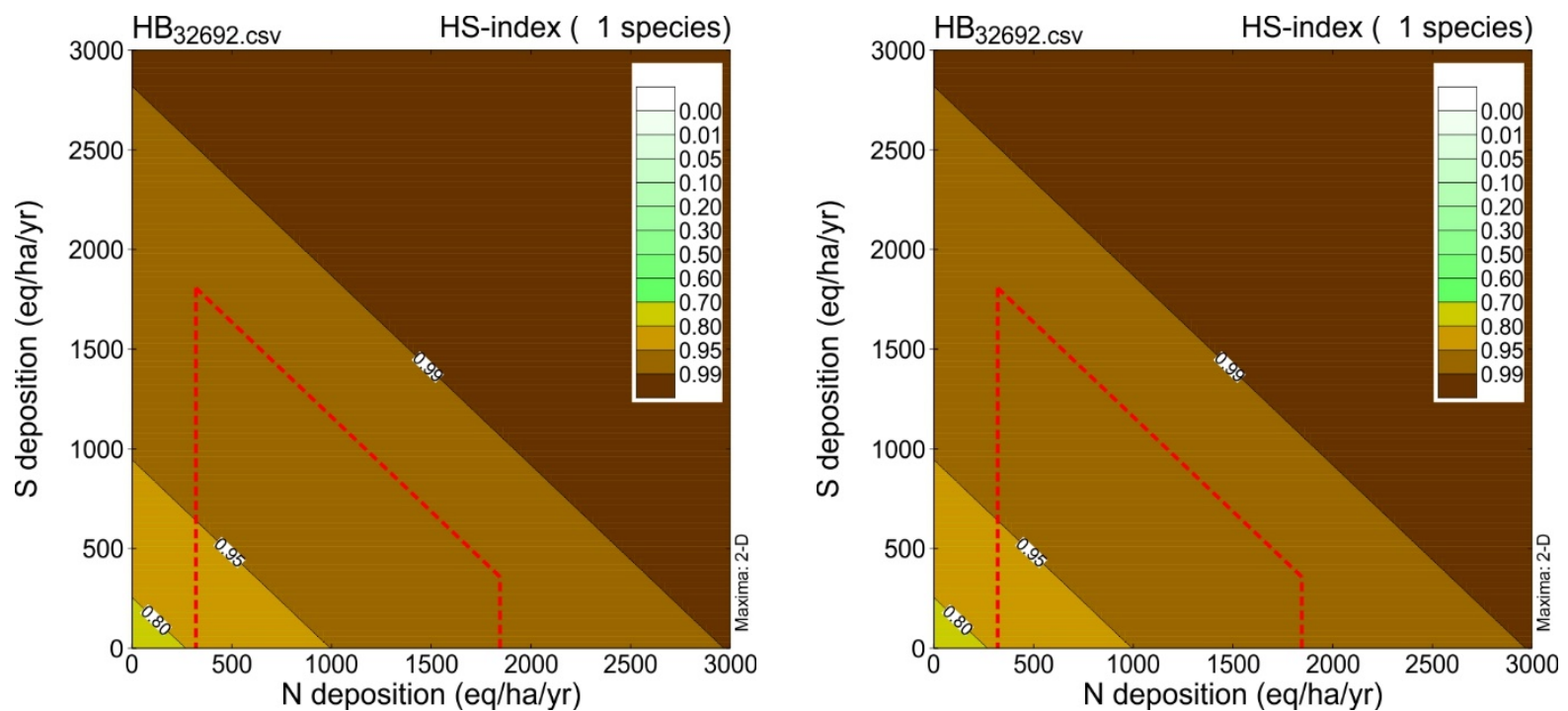
Trientalis borealis - 75\% (left) and 95\% (right) of maximum occurrence probability.
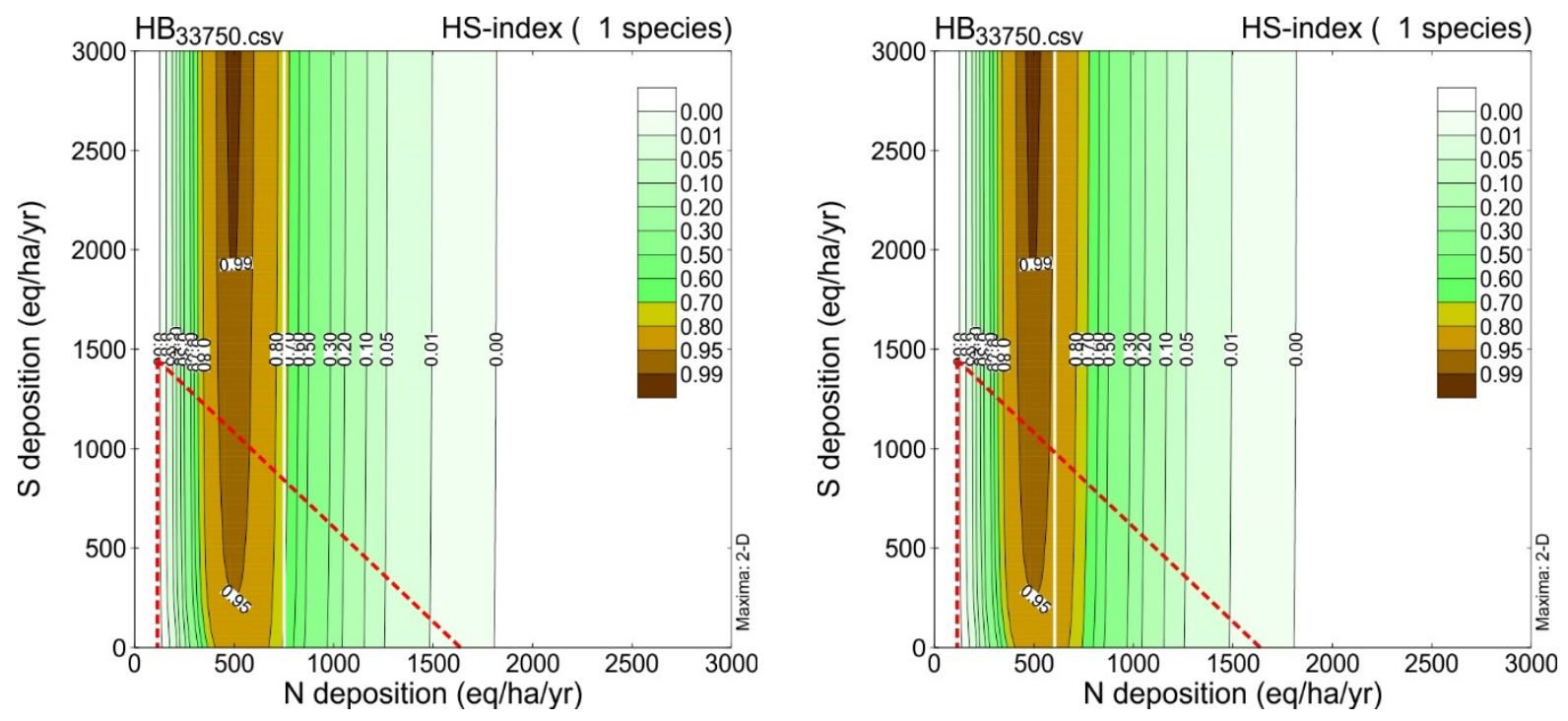

Trillium undulatum- $75 \%$ (left) and 95\% (right) of maximum occurrence probability.
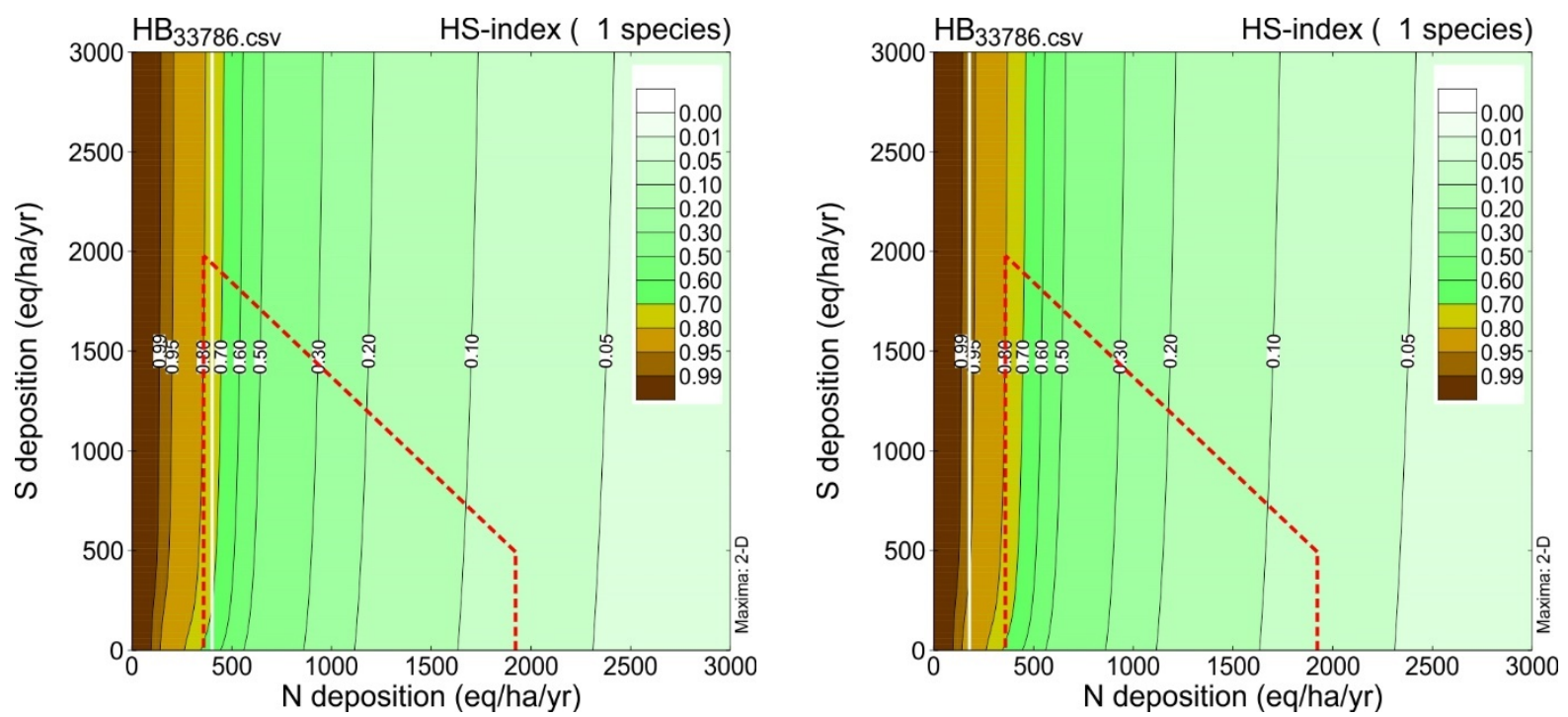
Acer pensylvanicum - 75\% (left) and $95 \%$ (right) of maximum occurrence probability.
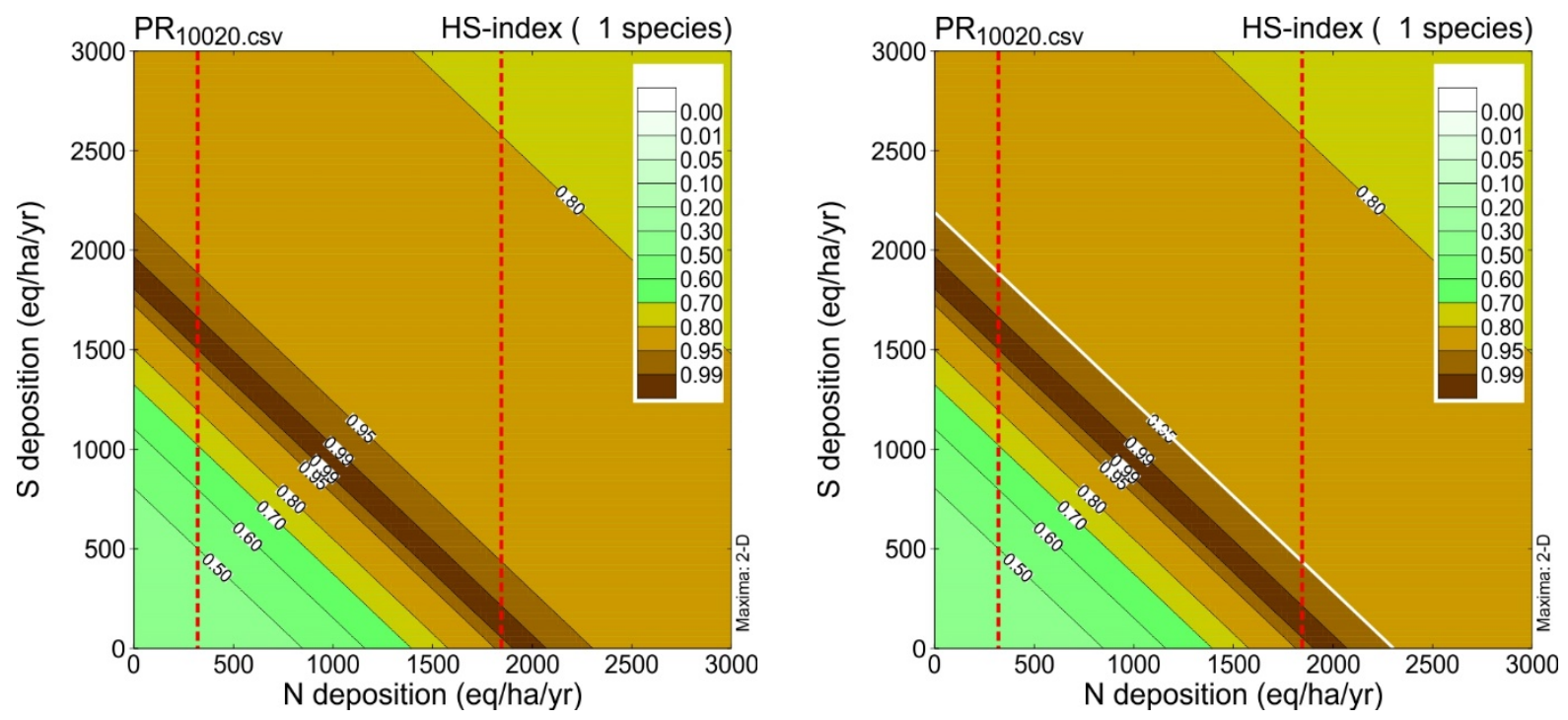

Carya ovata-75\% (left) and 95\% (right) of maximum occurrence probability.
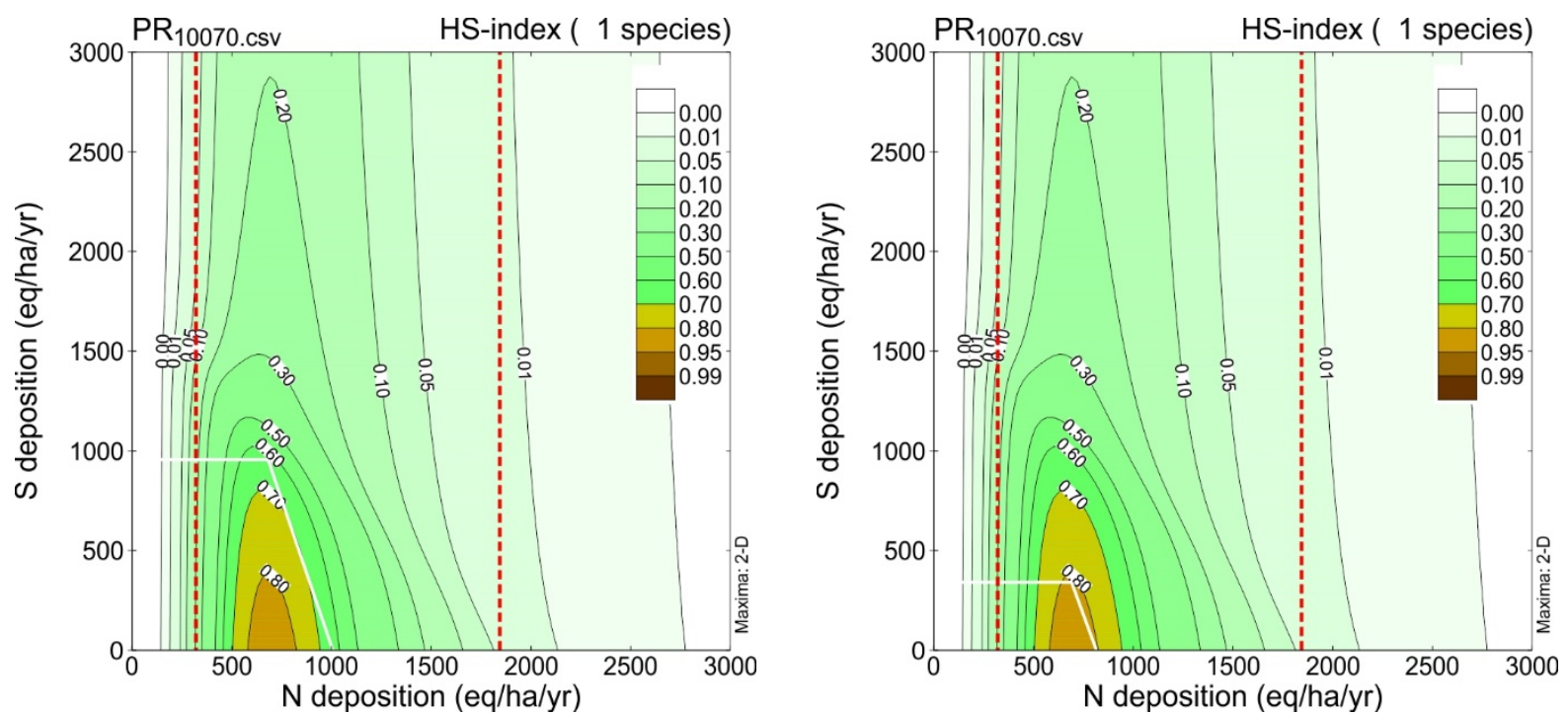
Fraxinus Americana-75\% (left) and 95\% (right) of maximum occurrence probability.
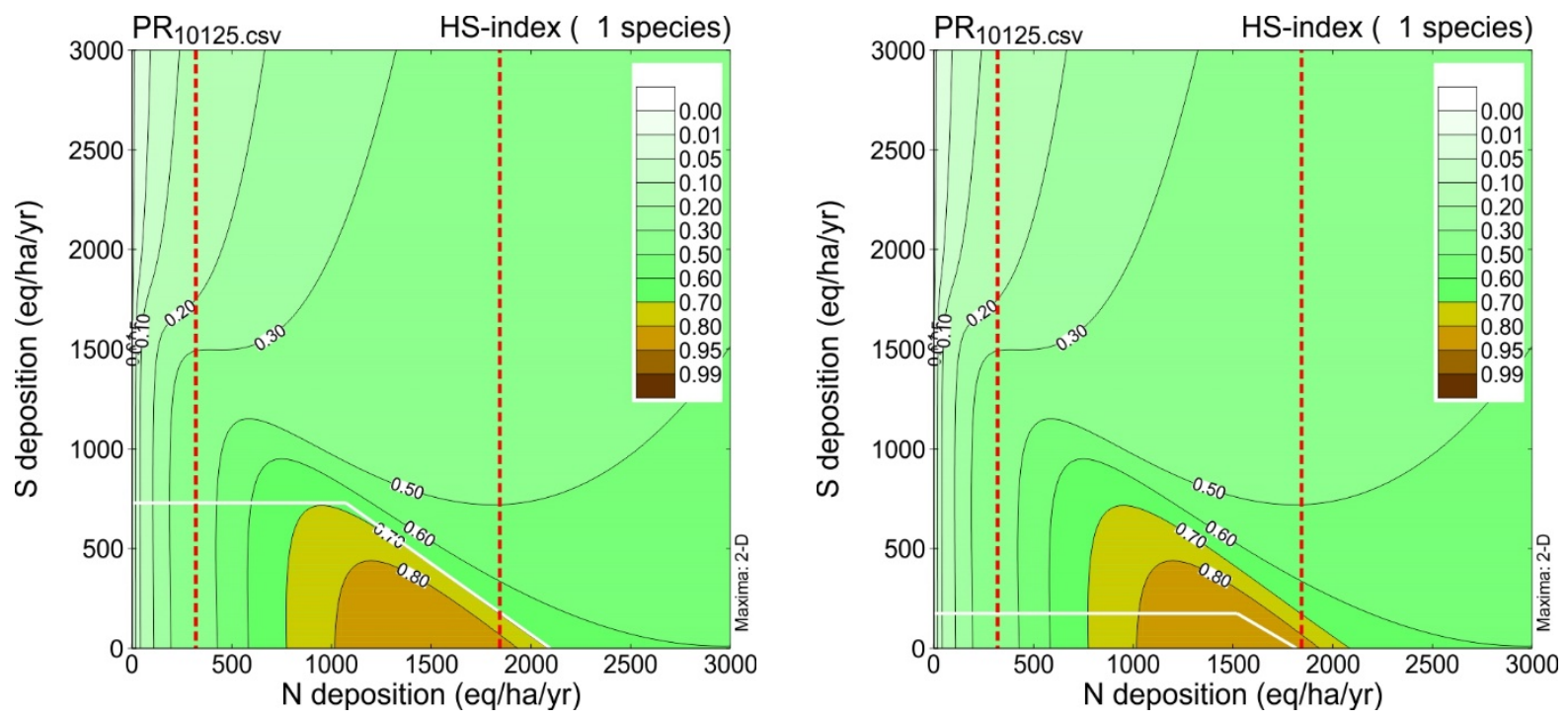

Prunus virginiana-75\% (left) and 95\% (right) of maximum occurrence probability.
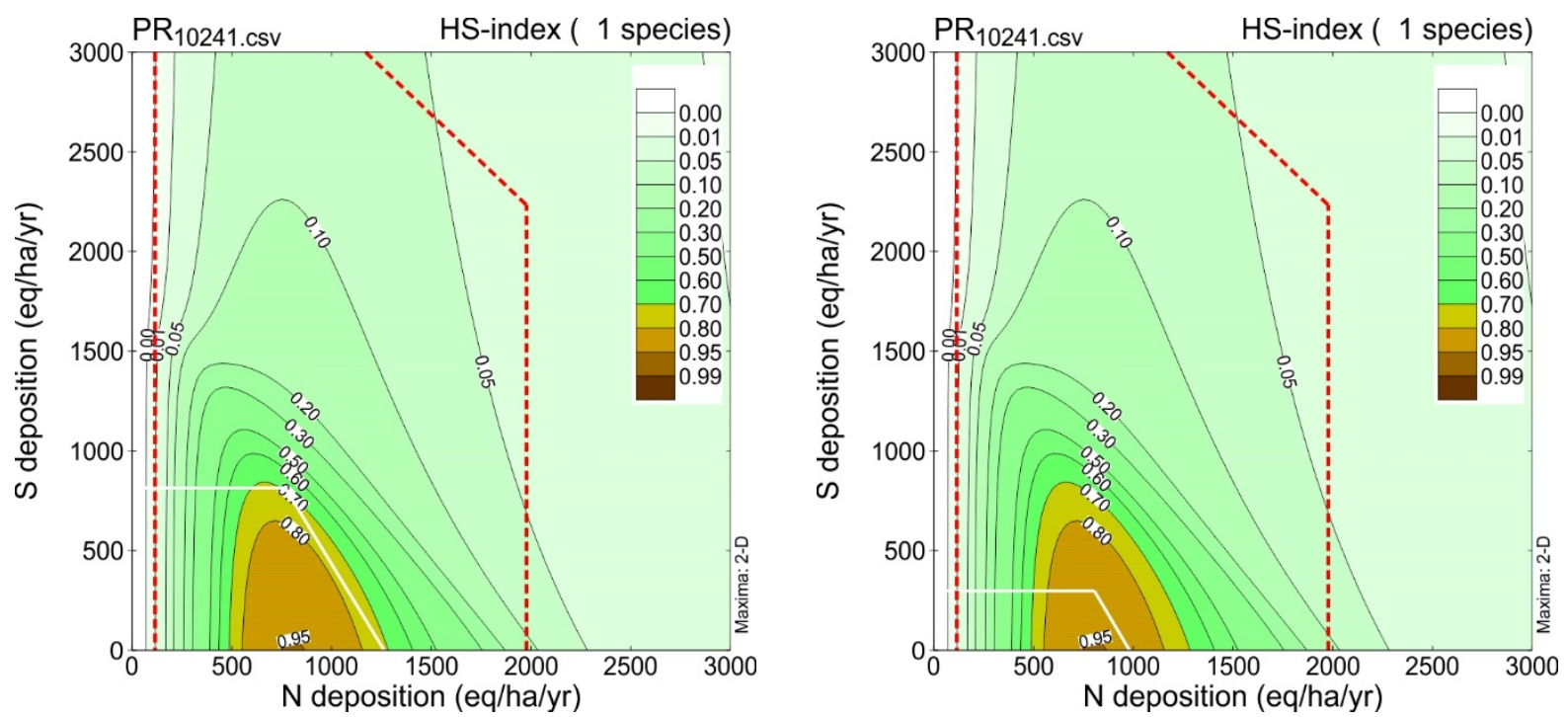
Quercus alba-75\% (left) and $95 \%$ (right) of maximum occurrence probability.
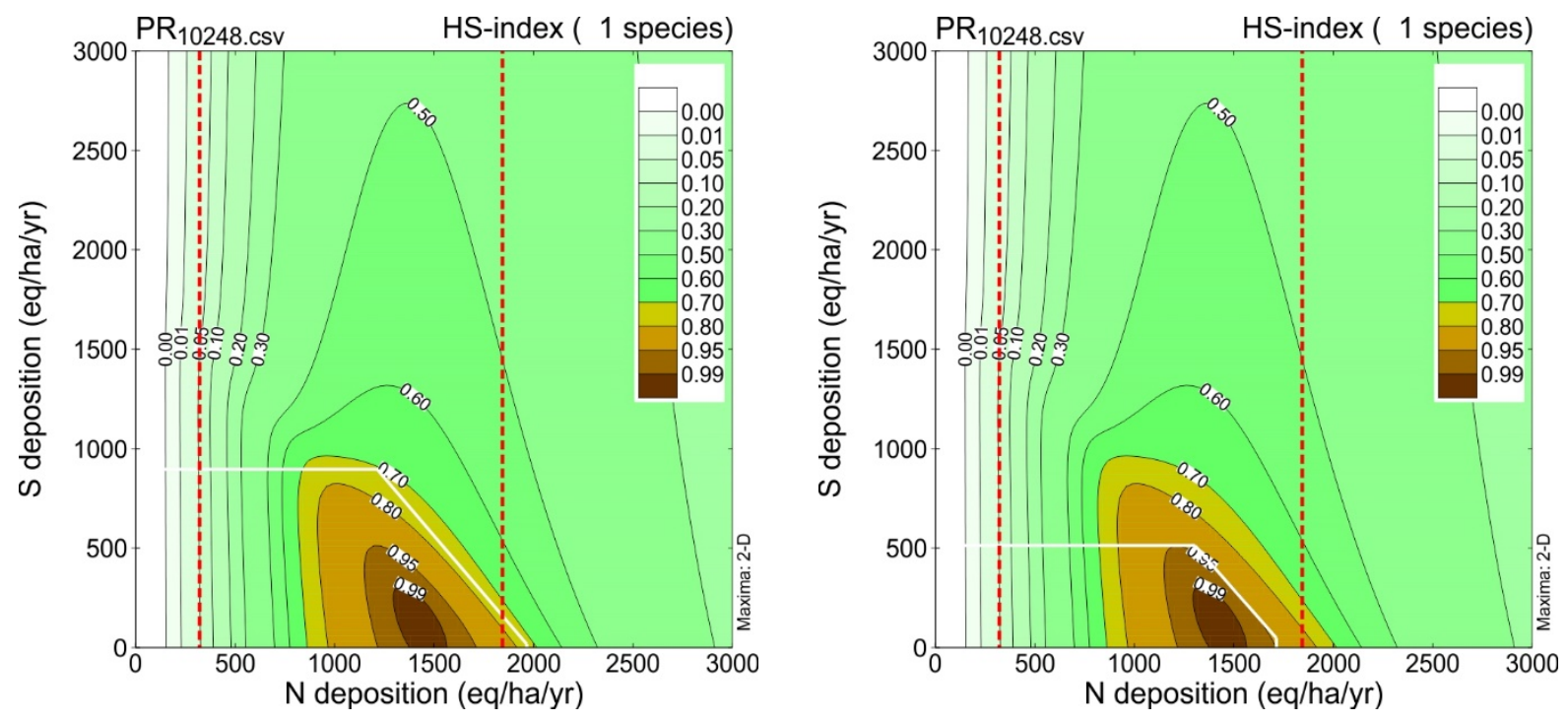

Actaea racemosa- $75 \%$ (left) and 95\% (right) of maximum occurrence probability.
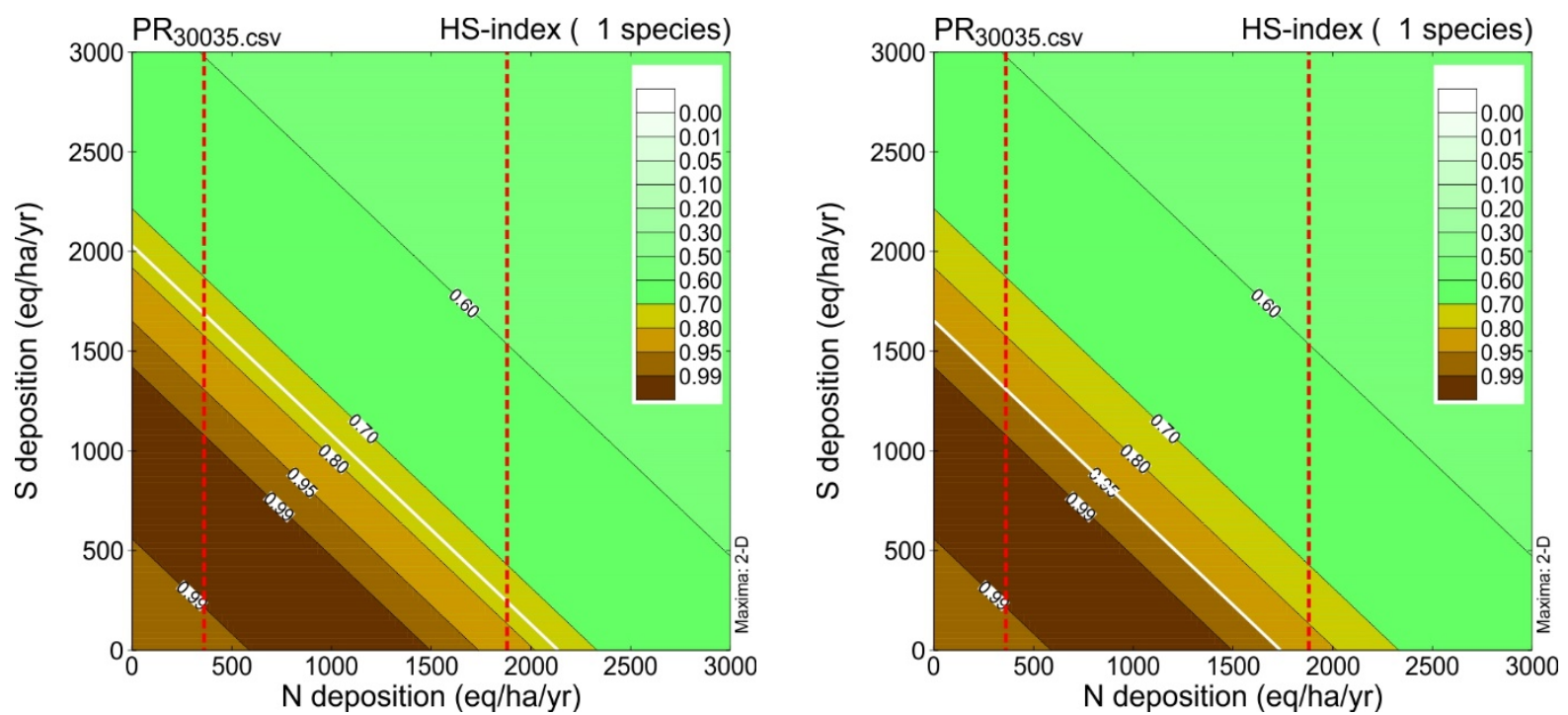
Hydrophyllum virginianum - 75\% (left) and 95\% (right) of maximum occurrence probability.
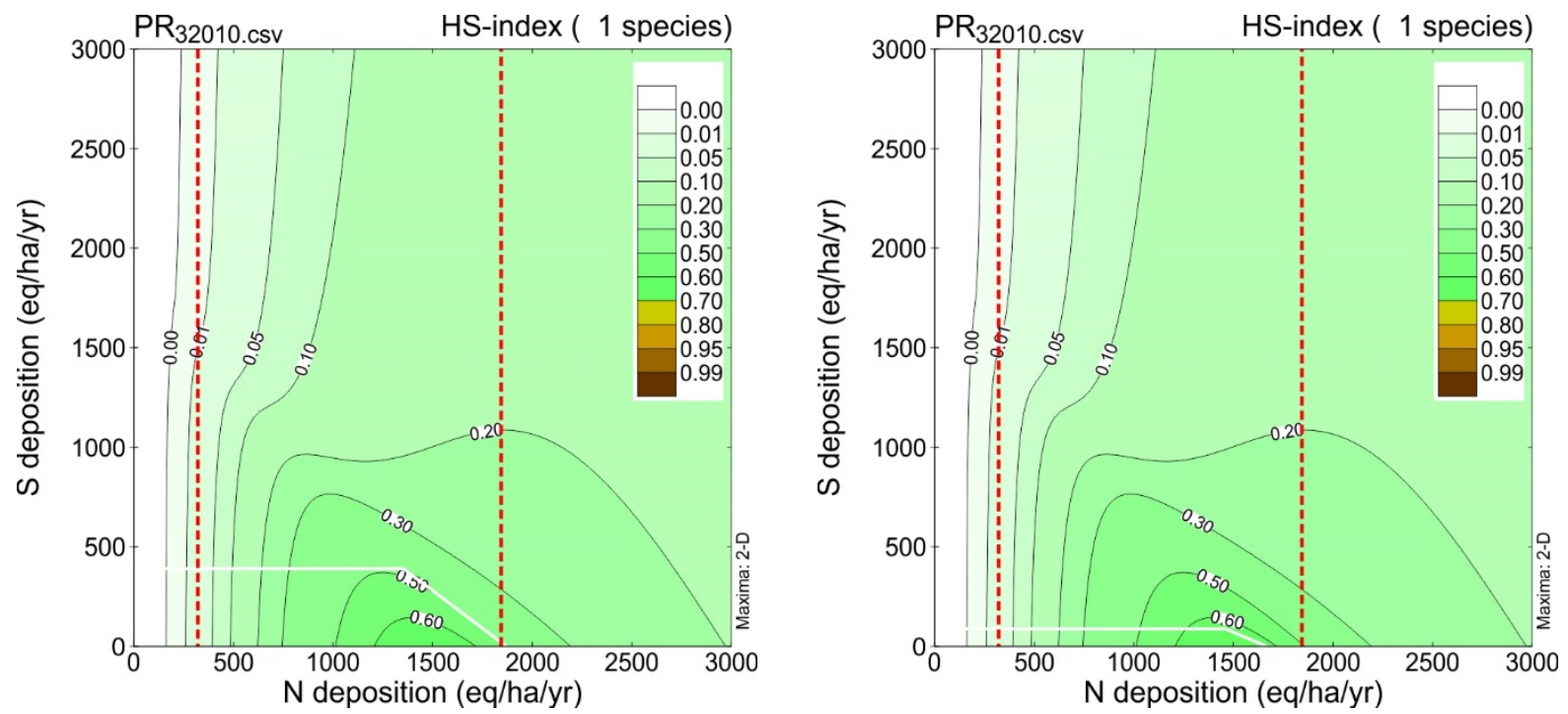
Acer pensylvanicum - 75\% (left) and 95\% (right) of maximum occurrence probability.
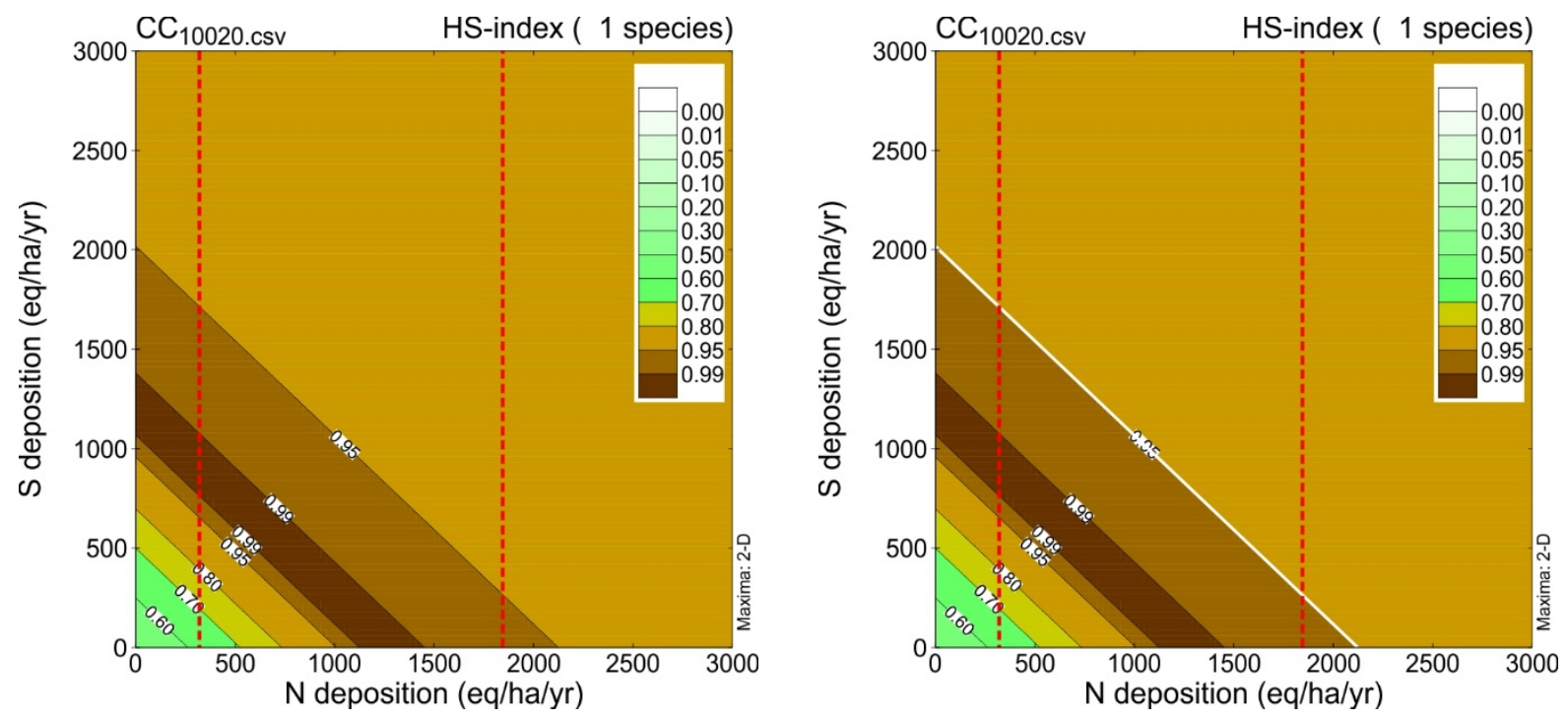

Acer saccharum - 75\% (left) and 95\% (right) of maximum occurrence probability.
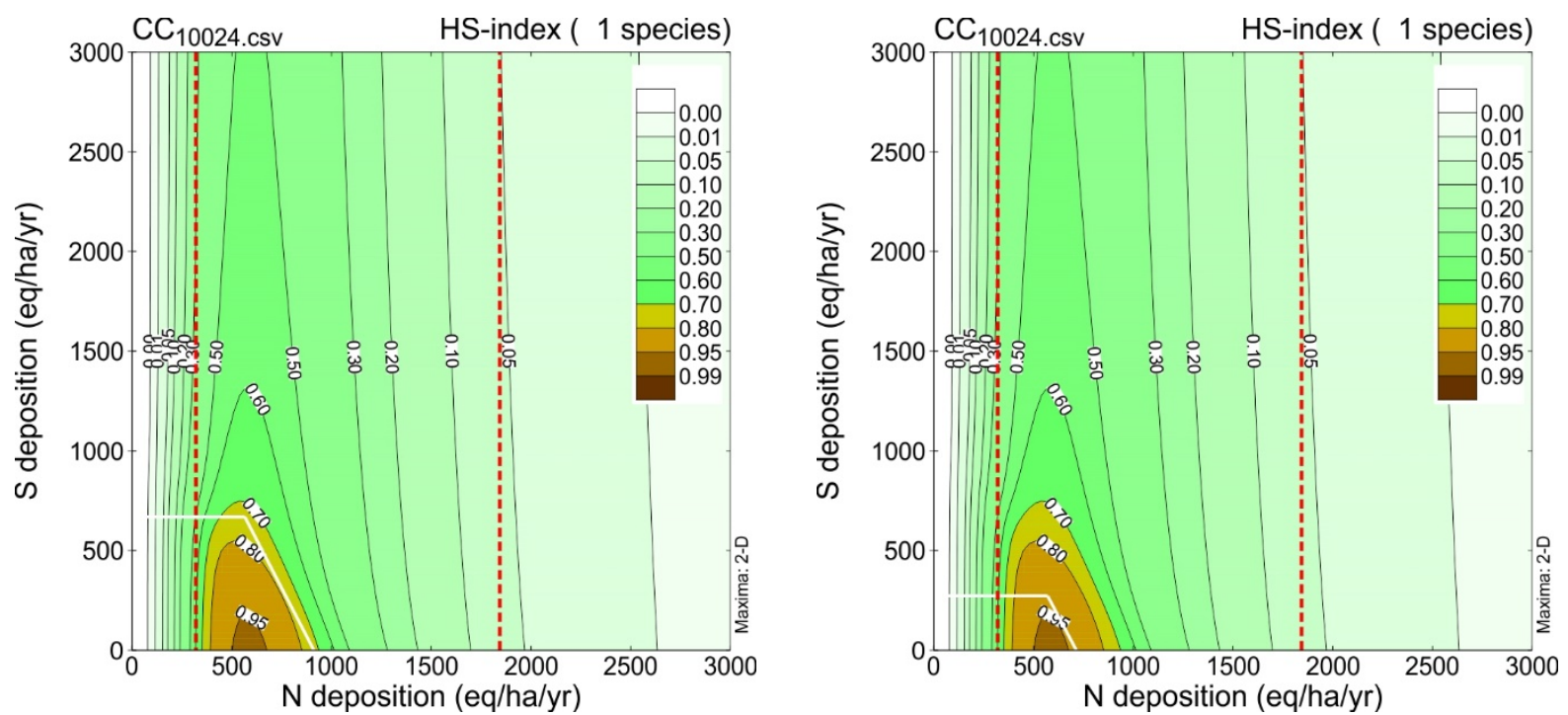
Quercus rubra-75\% (left) and 95\% (right) of maximum occurrence probability.
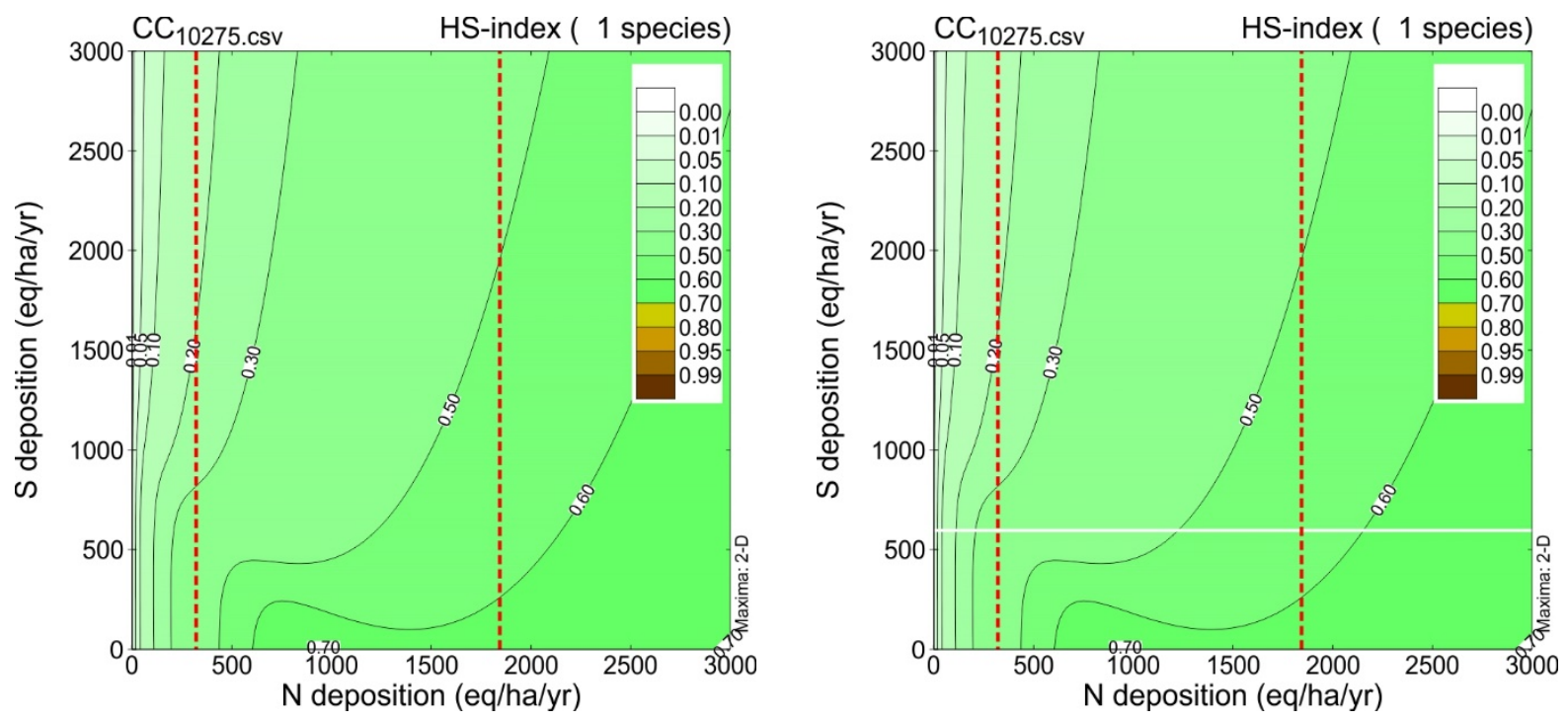

Ageratina altissima - 75\% (left) and 95\% (right) of maximum occurrence probability.
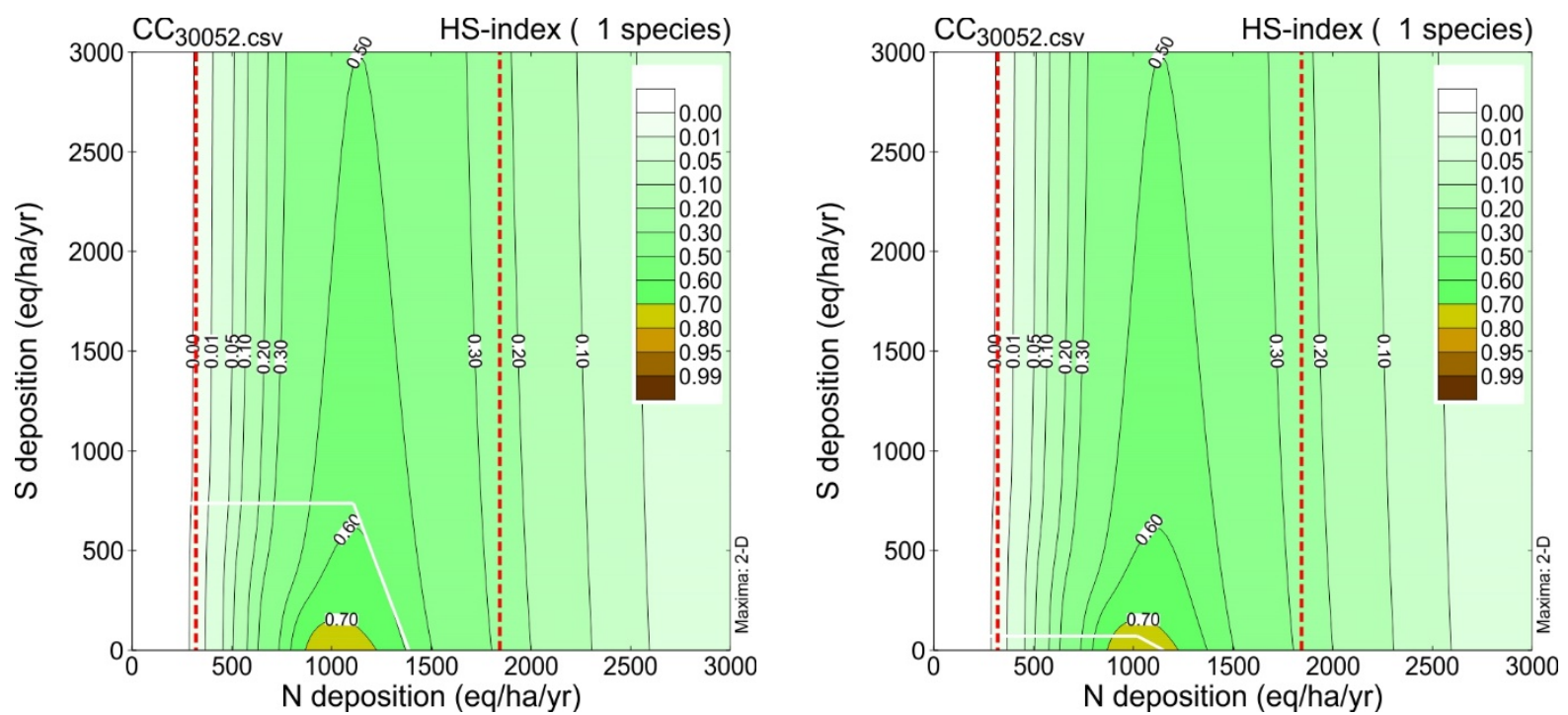
Laportea canadensis - 75\% (left) and $95 \%$ (right) of maximum occurrence probability.
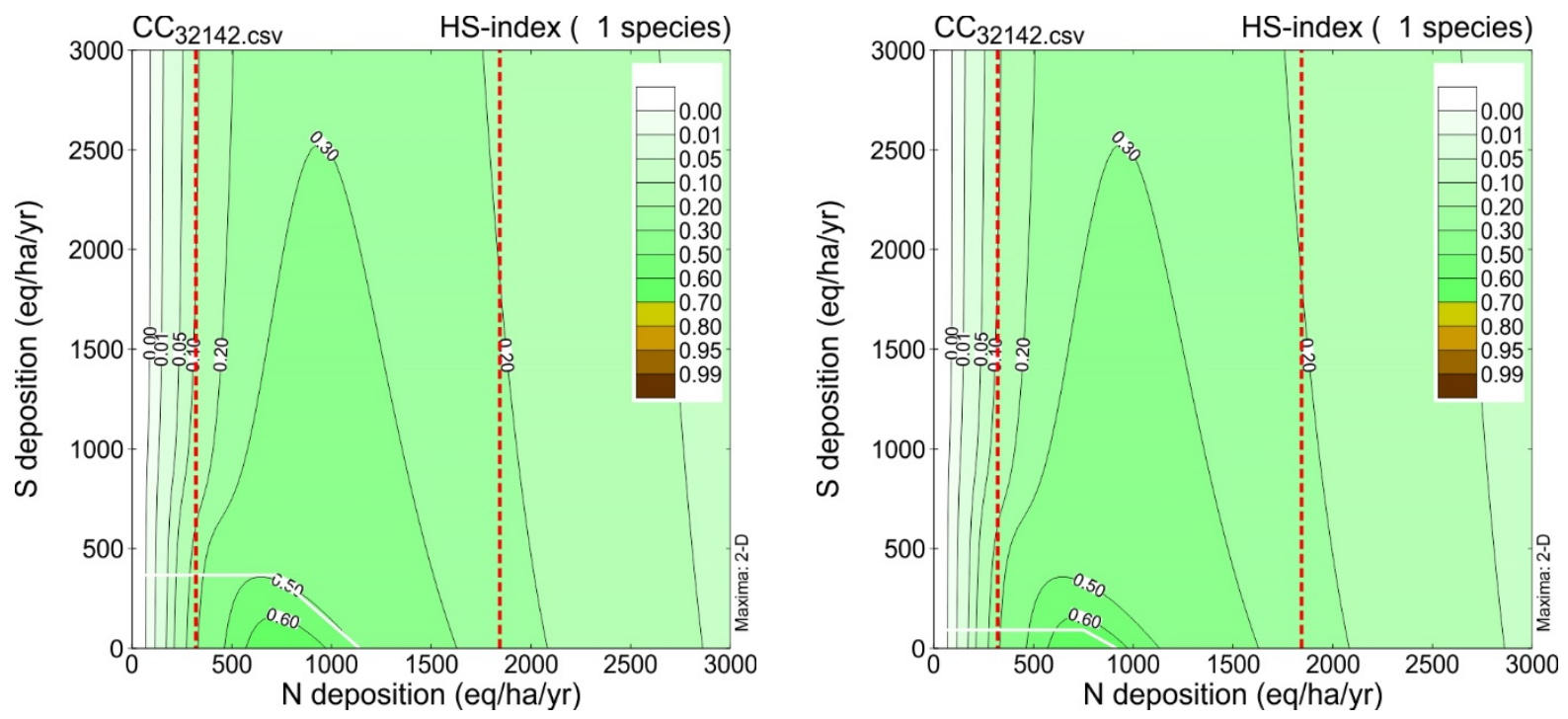

Maianthemum racemosum - 75\% (left) and 95\% (right) of maximum occurrence probability.
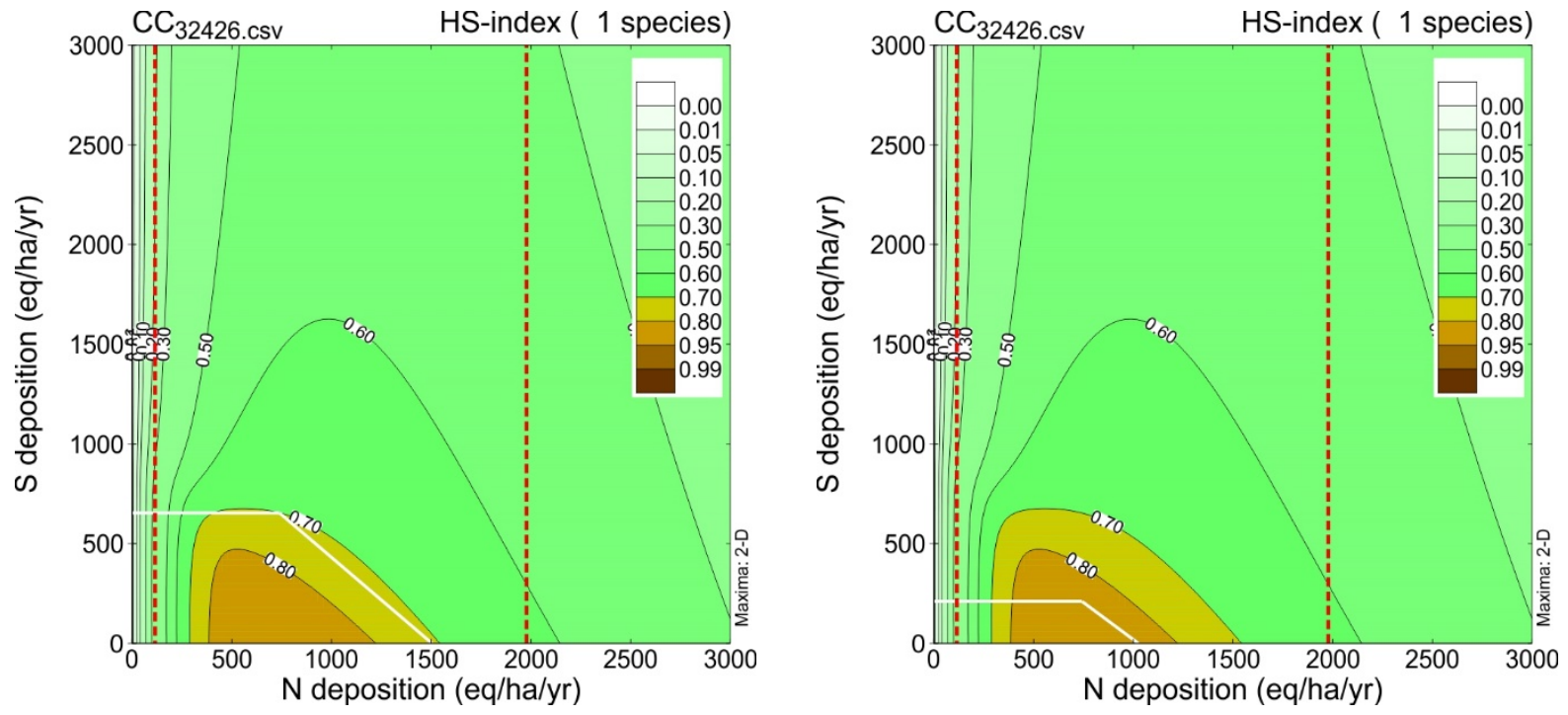


\section{Supplemental Material 11.}

Table SM11-1. Estimated critical loads of $\mathrm{N}$ and $\mathrm{S}$ deposition to attain $95 \%$ of the maximum occurrence probability (CL95) in units of $\mathrm{meq} / \mathrm{m}^{2} / \mathrm{yr}$ (and $\mathrm{kg} / \mathrm{ha} / \mathrm{yr}$ ) across all indicator species at Hubbard Brook (HB), Piney River (PR), and Cosby Creek (CC). The cells highlighted grey indicate exceedance of the CL for S. "NA" indicates that the specified occurrence probability was not attainable. Average annual ambient $\left(2014\right.$ - 2016) N deposition for HB, PR, and CC was: $36 \mathrm{meq} / \mathrm{m}^{2} / \mathrm{yr}, 65 \mathrm{meq} / \mathrm{m}^{2} / \mathrm{yr}$, and 54 $\mathrm{meq} / \mathrm{m}^{2} / \mathrm{yr}$, respectively. Average annual ambient $(2014-2016) \mathrm{S}$ deposition for HB, PR, and CC was: $17 \mathrm{meq} / \mathrm{m}^{2} / \mathrm{yr}, 20 \mathrm{meq} / \mathrm{m}^{2} / \mathrm{yr}$, and $19 \mathrm{meq} / \mathrm{m}^{2} / \mathrm{yr}$, respectively.

\begin{tabular}{|c|c|c|c|c|c|c|c|}
\hline & & \multicolumn{2}{|c|}{ Ambient Temp. } & \multicolumn{2}{|c|}{$+1.5^{\circ} \mathrm{C}$} & \multicolumn{2}{|c|}{$+3^{\circ} \mathrm{C}$} \\
\hline Site & $\begin{array}{c}\text { Number } \\
\text { of } \\
\text { Indicator } \\
\text { Species }\end{array}$ & $\begin{array}{c}\text { CL95 of N } \\
\text { (at Ambient } \\
\text { S Dep) }\end{array}$ & $\begin{array}{c}\text { CL95 of } S \\
\text { (at Ambient } \\
\text { N Dep) }\end{array}$ & $\begin{array}{c}\text { CL95 of N } \\
\text { (at Ambient } \\
\text { S Dep) }\end{array}$ & $\begin{array}{c}\text { CL95 of S } \\
\text { (at Ambient } \\
\text { N Dep) }\end{array}$ & $\begin{array}{c}\text { CL95 of N } \\
\text { (at Ambient } \\
\text { S Dep) }\end{array}$ & $\begin{array}{c}\text { CL95 of S } \\
\text { (at Ambient } \\
\text { N Dep) }\end{array}$ \\
\hline HB & 12 & $60(8.4)$ & $52(8.3)$ & $53(7.4)$ & $30(4.8)$ & NA & NA \\
\hline PR & 7 & 139 (19.4) & $62(9.9)$ & $134(18.7)$ & $58(9.3)$ & $123(17.2)$ & $47(7.5)$ \\
\hline $\mathrm{CC}$ & 6 & $84(11.7)$ & $17(2.7)$ & $89(12.4)$ & $6(1)$ & NA & NA \\
\hline
\end{tabular}


Cook, R.D. and S. Weisberg. 1982. Residuals and Influence in Regression. Chapman and Hall, London.

Fu, P. and P.M. Rich. 2002. A geometric solar radiation model with applications in agriculture and forestry. Computers and Electronics in Agriculture 37:25-35.

Galloway, J.N., F.J. Dentener, D.G. Capone, E.W. Boyer, R.W. Howarth, S.P. Seitzinger, G.P. Asner, C. Cleveland, P.A. Green, E.A. Holland, D.M. Karl, A.F. Michaels, J.H. Porter, A.R. Townsend, and C.J. Vorosmarty. 2004. Nitrogen cycles: past, present, and future. Biogeochemistry 70:153-226.

Gronberg, J.M., A.S. Ludtke, and D.L. Knifong. 2014. Estimates of Inorganic Nitrogen Wet Deposition from Precipitation for the Conterminous United States, 1955-84. Scientific Investigations Report 2014-5067. U.S. Geological Survey, Reston, VA.

Mahalanobis, P.C. 1936. On the generalised distance in statistics. Proceedings of the National Institute of Sciences of India 2(1):49-55.

McDonnell, T.C., G.J. Reinds, T.J. Sullivan, C.M. Clark, L.T.C. Bonten, J.P. Mol-Dijkstra, G.W.W. Wamelink, and M. Dovciak. 2018. Feasibility of coupled empirical and dynamic modeling to assess climate change and air pollution impacts on temperate forest vegetation of the eastern United States. Environ. Pollut. 234:902-914. doi.org/10.1016/j.envpol.2017.12.002.

Posch, M. 2017. PROPS-CLF User Manual. Version 1.4. Coordination Centre for Effects, National Institute for Public Health and the Environment, Bilthoven, The Netherlands.

Posch, M., W. de Vries, and J.-P. Hettelingh. 1995. Critical loads of sulfur and nitrogen. In: Posch, M., P.A.M. de Smet, J.P. Hettelingh and R.J. Downing (Eds.). Calculation and Mapping of Critical Thresholds in Europe. Status Report 1995. Coordination Center for Effects, National Institute of Public Health and the Environment (RIVM), Bilthoven, The Netherlands. pp. 31-41.

Posch, M., W. de Vries, and H.U. Sverdrup. 2015a. Mass balance models to derive critical loads of nitrogen and acidity for terrestrial and aquatic ecosystems. In: de Vries, W., J.-P. Hettelingh and M. Posch (Eds.). Critical Loads and Dynamic Risk Assessments. Nitrogen, Acidity, and Metals in Terrestrial and Aquatic Ecosystems. Environmental Pollution 25. Springer, Dordrecht. pp. 171-205.

Posch, M., J.-P. Hettelingh, J. Slootweg, and G.J. Reinds. 2014. Deriving critical loads based on plant diversity targets. Chapter 3. In: Slootweg, J., M. Posch, J.-P. Hettelingh and L. Mathijssen (Eds.). Modelling and Mapping the Impacts of Atmospheric Deposition on Plant Species Diversity in Europe. CCE Status Report 2014. Coordination Centre for Effects, National Institute for Public Health and the Environment. pp. 41-46.

Posch, M., J.-P. Hettelingh, J. Slootweg, and G.J. Reinds. 2015b. Critical loads for plant species diversity. In: Slootweg, J., M. Posch and J.P. Hettelingh (Eds.). Modelling and Mapping the Impacts of Atmospheric Deposition of Nitrogen and Sulphur. CCE Status Report 2015. Coordination Centre for Effects, National Institute for Public Health and the Environment, Bilthoven, the Netherlands. pp. 45-54. 